\title{
Molecular Characterization of Tobacco rattle virus proteins involved in pathogenicity
}

\author{
Dissertation \\ to obtain the $\mathrm{Ph}$. D. degree \\ in the Faculty of Agricultural Sciences, \\ Georg-August-University Göttingen, Germany \\ Presented by \\ Walid Ghazala
}

born in Kuwait, 05.08.1968

Göttingen, May 2007 
D7

1. Name of referee: Prof. Dr. Mark Varrelmann

2. Name of co-referee: Prof. Dr. Edgar Maiss

Date of dissertation: 24.05.2007 


\section{TABLE OF CONTENTS}

List of Abbreviations

Chapter 1

Chapter 2

Chapter 3

Chapter 4

Summary

Acknowledgments

Curriculum Vitae
General Introduction.

1. Potato and potato viruses $\ldots \ldots \ldots \ldots \ldots \ldots \ldots \ldots \ldots \ldots \ldots \ldots \ldots \ldots \ldots \ldots \ldots \ldots, 1$

2. Tobacco rattle virus (TRV)................................... 2

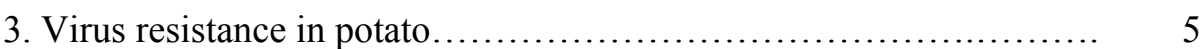

4. Breeding for virus-resistance in $S$. tuberosum ..................... 9

5. RNA silencing in plants................................................. 12

6. Requirements for efficient silencing suppression by plant VSR...... 15

7. Justifications and objectives....................................... 17

Tobacco rattle virus $29 \mathrm{~K}$ movement protein is the elicitor of extreme and hypersensitive-like resistance in two cultivars of Solanum tuberosum

- Abstract ........................................................................................ 33

- Introduction .............................................. 34

- Results....................................................... 36

- Discussion ................................................................... 47

- Materials and Methods........................................... 51

- Literature cited .................................................. 55

- Supplementary Figures....................................... 61

Functional characterization and subcellular localization of the $16 \mathrm{~K}$ cysteine-rich suppressor of gene silencing protein of Tobacco rattle virus...

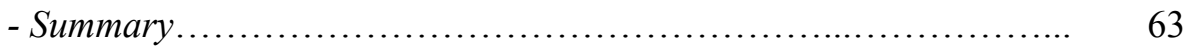

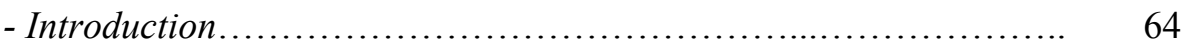

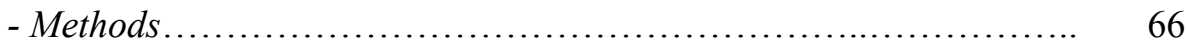

- Results.................................................. 70

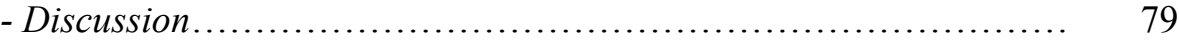

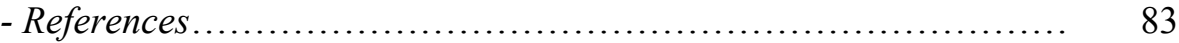

General Discussion............................................... 91 


\section{LIST OF ABBREVIATIONS}

aa

Acc.

AFLP

AP

$a v r$

BCIP

BNYVV

bp

BSMV

${ }^{\circ} \mathrm{C}$

CaMV

CC-NBS-LRRs

cDNA

CLSM

$\mathrm{cm}$

$\mathrm{CP}$

CRP

cV.

DICER

DNA

dpi

dsDNA

DsRed

DTT

ER

ER-trageting signal

EU

Fig.

FM

GFP

GRS

HA-tag

$\mathrm{HCl}$

His-tag

HIV

hnRNP

HR

IgG

IL

$\mathrm{kDa}$

LRRs

LZ-NBS-LRRs

$\mathrm{M}$

M-type

MAS amino acid

accession

amplified fragment length polymorphism

alkaline phosphatase

avirulence

5-bromo-4-chloro-3-indolyl phosphate, p-toluidine salt

Beet necrotic yellow vein virus

base pairs

Barley stripe mosaic virus

centigrade

Cauliflower mosaic virus

coiled-coil nucleotide binding site leucine-rich repeats

complementary DNA

confocal laser scanning microscopy

centimeter

coat protein

cysteine-rich protein

cultivar

an enzyme belongs to the RNase III family of nucleases that specifically cleave dsRNAs

deoxyribonucleic acid

day(s) post infection

double-stranded DNA

Discosoma red fluorescent protein

dithiothreitol

extreme resistance

endoplasmic reticulum targeting signal

European Union

figure

epifluorescence microscopy

green fluorescent protein

groundnut rosette virus

haemagglutinin-tag

hydrogen chloride

histidin-tag

Human immunodeficiency virus

heterogeneous nuclear RNP (a major pre-mRNA/mRNA binding protein in eukaryotic cells)

hypersensitive resistance/reaction

immunoglobulin $\mathrm{G}$

interleukin

kilo Dalton

leucine-rich repeats

leucine-zipper nucleotide binding site leucine-rich repeats

molar

multiplying type

marker-assisted selection 


\begin{tabular}{|c|c|}
\hline$\mu \mathrm{g}$ & microgram \\
\hline $\mathrm{ml}$ & mililitre \\
\hline MGS & mutation generation system \\
\hline miRNA & microRNA \\
\hline $\mathrm{mg}$ & miligram \\
\hline$\mu 1$ & microliter \\
\hline MP & movement protein \\
\hline mRFP & monomeric red fluorescent protein \\
\hline mRNA & messanger RNA \\
\hline MW & molecular weight \\
\hline NBS & nucleotide binding site \\
\hline NBT & nitro blue tetrazolium chloride \\
\hline NES & nuclear export signal \\
\hline NLS & nuclear localization signal \\
\hline NM-type & non-multiplying type \\
\hline No. & number \\
\hline $\mathrm{nt}$ & nucleotide \\
\hline ntr & non-translatable \\
\hline OD & optical density \\
\hline ORF & open reading frame \\
\hline PBS & phosphate buffered saline \\
\hline PCR & polymerase chain reaction \\
\hline PCV & Peanut clump virus \\
\hline PEBV & Pea early-browning virus \\
\hline PepRSV & Pepper ringspot virus \\
\hline $\mathrm{pH}$ & potential of hydrogen \\
\hline PLRV & Potato leafroll virus \\
\hline PMTV & Potato mop-top virus \\
\hline PolyA-terminator & polyadenylaion terminator/signal \\
\hline PPV & Plum pox virus \\
\hline PS & pentapeptide scanning \\
\hline PSLV & Poa semilatent virus \\
\hline PSM & pentapeptide scanning mutagenesis \\
\hline PTGS & post-transcriptional gene silencing \\
\hline PVA & Potato virus $A$ \\
\hline PVDF & polyvinylidene fluoride \\
\hline PVS & Potato virus $S$ \\
\hline PVV & Potato virus $V$ \\
\hline PVX & Potato virus $X$ \\
\hline PVY & Potato virus $Y$ \\
\hline QTLs & quantitative trait loci \\
\hline$R$-gene & resistance gene \\
\hline RAPD & random amplified polymorphic DNA \\
\hline $\mathrm{RB}$ & resistance-breaking \\
\hline $\operatorname{RdRp}$ & RNA-dependent RNA polymerase \\
\hline RFLP & restriction fragment length polymorphism \\
\hline RISC & RNA-induced silencing complex \\
\hline RNA & ribonucleic acid \\
\hline RNAi & RNA interference \\
\hline RT-PCR & reverse transcriptase-PCR \\
\hline
\end{tabular}


SAR

SBWMV

SDM

SDS-PAGE

sg

$\operatorname{sgPr}$

siRNA

SMV

ssp.

ssRNA

STS

SV40

TBS

TBSV

TIR-NBS-LRRs

TEV

TMV

tnos

ToMV

TRV

UV

$\mathrm{v} / \mathrm{v}$

var.

VIGS

VSR systemic acquired resistance

Soilborne wheat mosaic virus

site-directed mutagenesis

sodium dodecyl sulphate-polyacrylamide gel electrophoresis

subgenomic

subgenomic promotor

small interfering RNA

Soybean mosaic virus

subspecies

single-stranded RNA

silver thiosulfate solution

Simian virus 40

tris buffer saline

Tomato bushy stunt virus

Toll and Interleukin-1 receptor nucleotide binding site leucine-rich repeats

Tobacco etch virus

Tobacco mosaic virus

nopaline synthase terminator sequence

Tomato mosaic virus

Tobacco rattle virus

ultraviolet

volume per volume

Variety

virus-induced gene silencing

viral suppressor of RNA silencing 


\section{CHAPTER 1}

\section{General Introduction}

\section{Potato and potato viruses}

\subsection{Cultivated potato: taxonomy, importance and genetics}

The genus "Solanum", family "Solanaceae", includes the tuber-bearing species, of which the cultivated potato "Solanum tuberosum ssp. tuberosum" is best known (Correll 1962; Ross 1986). Worldwide, cultivated potato is one of the most important widely grown crops, ranking fourth after wheat, maize, and rice, respectively (Hawkes 1990; Ross 1986). The growing utilization of this crop, not only as a consumer good, but also as a highly requested commodity for the industrial sector, justifies its rising expansion at the expense of many other important crops. The potato is very rich in genetic resources in comparison with many other cultivated crops (Ross 1986). Ploidy in potato (both wild and cultivated) has a series of levels, ranging from diploid $(2 \mathrm{n}=24)$ to hexaploid $(6 \mathrm{n}=72)$ (Dodds 1962). S. tuberrosum, in particular, is self-compatible outbreeding tetraploid $(2 \mathrm{n}=4 \mathrm{x}=48)$ (Bradshaw and Mackay 1994). It is a highly heterozygous autotetraploid with a tetrasomic inheritance (Cadman 1942; Howard 1970); however, Ross (1958) has observed a disomic inheritance in some crossings where $S$. tuberosum is one of the two parents. It is believed that the subspecies tuberosum is derived from the tetraploid S. tuberosum ssp. andigena (Bradshaw and Mackay 1994). More details on potato genetics can be found in Gebhardt and Valkonen (2001) and Solomon-Blackburn and Barker (2001a).

\subsection{List of potato viruses and their damage}

Potatoes are naturally susceptible to about forty viruses and two viroids (Jeffries et al. 2005). One should take into account that frequency of appearance of any particular virus in potatoes may vary from year to year and by region; however, Potato leafroll virus (PLRV) and Potato virus $Y$ (PVY), and to a lesser extent Potato virus $X$ (PVX), have continued to be the most damaging and widespread viruses to threaten potato cultivation throughout the last decade (Ross 1986; Solomon-Blackburn and Barker 2001b). For a list of other potato viruses and 
their importance, see De Bokx and van der Want (1987). Generally, a virus infection can cause substantial loss in the potato crop (Valkonen et al. 1996), which translates into millions of dollars wasted per year. Some viruses have effects on the quality of potato tubers. For instance, Potato mop-top virus (PMTV) causes necrotic symptoms in tubers (Sandgren et al. 2002), and a particular strain of PVY (PVY ${ }^{\mathrm{NTN}}$ ) causes necrotic ring blemishes on tubers (Beczner et al. 1984; Le Romancer et al. 1994). In respect to PMTV and PVY, Tobacco rattle virus (TRV) causes spraing symptoms in potatoes and severely affects tuber quality (Harrison and Robinson 1981). These symptoms, characterized by arcs and/or flecks of corky brown necrotic tissue in the flesh of affected tubers, destroy the crop's sale potential for human consumption and industrial use (Brown and Sykes 1973; Harrison and Robinson 1978).

\section{Tobacco rattle virus (TRV)}

\subsection{Genome organization}

TRV belongs to the genus "Tobravirus", which is also comprised of two other members, Peaearly browning virus (PEBV) and Pepper ringspot virus (PepRSV) (Harrison 1973; Robinson and Harrison 1989a\&b). The virus possesses a bipartite positive-single-stranded $(+)$ ssRNA genome (Fig. 1) with rigid rod-shaped particles (MacFarlane 1999). The larger RNA, RNA-1, codes for four open-reading frames (ORFs): a 134-kDa protein terminated by an opal stop codon and a 194-kDa protein produced by read-through of this stop codon, both of which are named the helicase/RNA polymerase (replicase) both which are believed to be involved in RNA replication (Hamilton and Baulcombe 1989); a 29-kDa (1a) movement protein (MP), which is involved in intercellular transport of the virus (Ziegler-Graff $\boldsymbol{e t}$ al . 1991); and a 16-kDa (1b) cysteine-rich protein (CRP), which functions as a pathogenicity determinant and a suppressor of gene silencing (Liu et al. 2002; Reavy et al. 2004). The smaller RNA, RNA-2, codes for a 23-kDa (2a) coat protein (CP) and, in case of PpK20 strain (Fig.1), two nonstructural proteins, a $40-\mathrm{kDa}(2 \mathrm{~b})$ required for transmission by the natural vector, and a $33-\mathrm{kDa}(2 \mathrm{c})$ with an unknown function. ORFs $1 \mathrm{a}, 1 \mathrm{~b}$, and $2 \mathrm{a}$ are expressed via subgenomic (sg) RNA. 


\subsection{RNA-2 variability and types of infection}

In contrast to RNA-1, RNA-2 from different TRV isolates has very little nucleotide sequence identity; thus, the virus is highly variable in nature and occurs as a large number of serotypes and strains (MacFarlane 1997). This variability of RNA-2 is due to recombination between tobraviruses, which may occur either predominantly in intragenic or non-coding regions (i.e. between strains or isolates of the same viral species) or between two different tobravirus species (MacFarlane 1999; Robinson 1994). For example, several studies have reported TRV/PEBV recombinants. (Goulden et al. 1991; Ploeg et al. 1991; Robinson et al. 1987). It has been reported that the recombined region in RNA-2 may encode a partial or complete copies of RNA-1 3'-nontranslated sequences (MacFarlane 1999). For example, the RNA-2 of TRV isolate TCM was found to acquire a 3' region derived from TRV RNA-1 (Angenent et al. 1986; Goulden et al. 1991). Also, a previous report has indicated that some tobravirus isolates include either a duplicate or a deletion sequence in the RNA-2 (MacFarlane 1997). Accordingly, serological detection of TRV becomes a very difficult procedure due to the need for a specific antiserum for each isolate. TRV can cause two types of infection: multiplying isolates (M-type), where both genomic RNAs are present; and non-multiplying isolates (NM-type). In M-type isolates, the virus produces nucleoprotein particles and is readily transmitted by sap-inoculated plants. NM-type isolates consist of only unencapsidated RNA-1, and can multiply and spread in the complete absence of RNA-2 but do not produce virus particles (MacFarlane 1999). Since the CP is encoded by RNA-2, NM-type isolates cannot be serologically detected, as no nucleoprotein particles are produced.

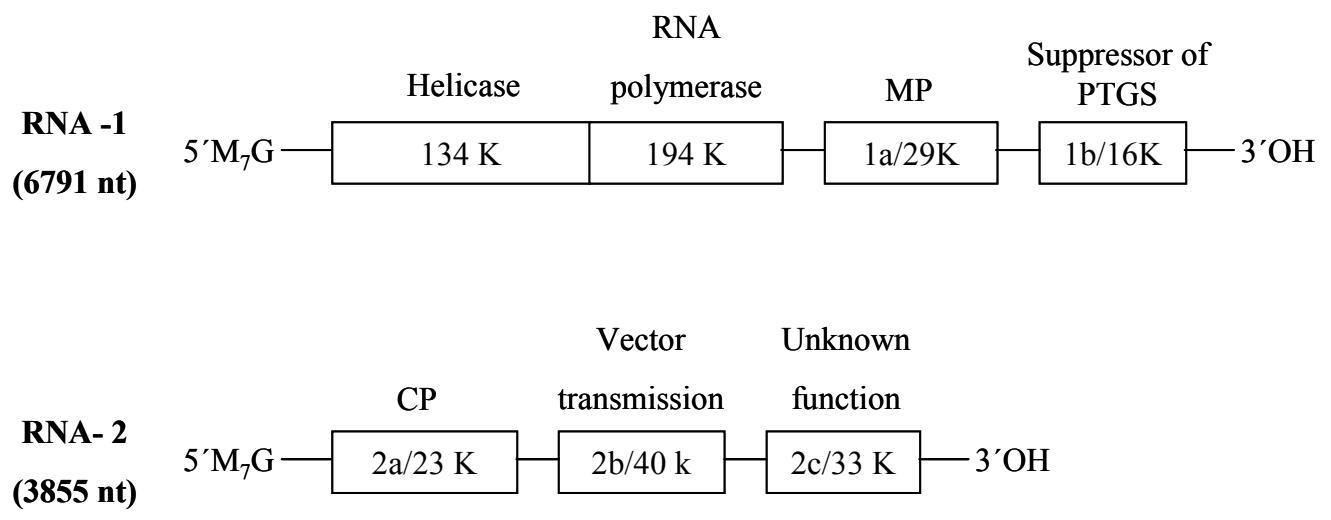

Fig. 1. Genome organization of TRV PpK20 isolate (MacFarlane 1999). 


\subsection{Nematode transmission and vector specificity}

Tobraviruses are naturally transmitted as intact virions by the soil-inhabiting Trichodorus and Paratrichodorus ectoparasites nematodes species which belong to the family Trichodoridae (trichodorids) (Taylor and Brown 1997; Van Hoof 1968). The $2 b$ protein encoded by RNA2 is essential for the transmission of tobravirus members by their vectors (Hernández et al. 1997; Vassilakos et al. 2001; Vellios et al. 2002); therefore, NM-type infection cannot be transmitted by nematodes. Vector specificity, in that particular virus isolates may be transmitted only by certain nematode species, has previously described (Ploeg et al. 1992a\&b). Previous reports have indicated that an interaction between the virus and receptors within the nematode is a determinant factor, which may affect transmission efficiency and/or vector specificity, and that the $2 b$ gene determines this specificity (MacFarlane 1999\&2003).

\subsection{Host range and susceptibility of potato cultivars}

TRV has a widespread distribution (Visser et al. 1999). In field, more than 100 plant species have been found to be infected by TRV, while the virus can be transmitted by sap-inoculated plants to about 400 species in more than 50 families, including both mono- and dicotyledonous plants under laboratory conditions (Harrison and Robinson 1978; MacFarlane 1999). Variability in host reaction of potato cultivars to TRV nematode infection may have different patterns, and can be affected by several factors, such as virus strain, type of infection, or environmental conditions (Robinson et al. 2004). An early report has mentioned that tubers showing spraing symptoms were found to contain NM-type TRV infection (Harrison and Robinson 1981); however, a subsequent study demonstrated that spraing-affected tubers might contain NM- or M-type isolates (Harrison et al. 1983). In Mtype infection, the plant may become fully systemic without spraing developing in resulted tubers (Xenophontos et al. 1998). Such susceptible plants are usually regarded "tolerant" (described below). In some cases, as in cv. 'Wilja', the fully systemic plants (showing no spraing) produced small secondary growth tubers which had a significant effect on the number of yield components and important quality attributes (Dale et al. 2000). Recently, Robinson et al. (2004) stated that "potato cultivars differ in their propensity to develop spraing symptoms"; they added, "almost any variety can be affected by spraing under certain 
conditions, including varieties such as 'Bintje' and 'Saturna' that are usually regarded as resistant”.

\subsection{TRV control and the need for resistance}

Several reports have pointed out the nonsuccess of most control programs based on controlling the vector transmission of potato viruses (Gebhardt and Valkonen 2001; Solomon-Blackburn and Barker 2001b). Controlling the vector transmission of TRV via nematicide applications has been very difficult due to the existence of nematodes in the deeper layers of soil (Harrison 1977). Additionally, the use of nematicides is prohibited in most countries of the European Union (EU) due to their unspecific mode of action, their toxicity, and their long persistence in soil. Biotests applied in screening for resistant potato plants to TRV are often inappropriate. For example, breeding programs based on serological detection of TRV RNA-2 in infected plants are surrounded with high risk, as spraing might develop from NM-type infections (as described above). On the other hand, selection for resistance to TRV only by exposure to viruliferous nematodes may not be very reliable either, as plants might become fully infected but produce no spraing (tolerance). Selecting such tolerant lines may increase the risk of virus spreading from infected symptomless stocks (Solomon-Blackburn and Barker 2001b). Therefore, searching for host resistance sources to TRV infection is the best solution for overcoming many, if not all, the problems presented above.

\section{Virus resistance in potato}

\subsection{Virus resistance mechanisms}

In susceptible potato plants, the virus can spread and multiply,. In this context, it has been suggested that tolerant (without symptoms) potato plants can be regarded as susceptible to infection, since the virus can multiply extensively (Solomon-Blackburn and Barker 2001b). In contrast, resistant plants involve different mechanisms to stop the virus from going further. Generally, the most accepted and widely used nomenclature of resistance to virus infection in potato plants is extreme resistance (ER) or hypersensitive resistance (HR). In ER plants, the virus localizes to the primary infection site with no obvious symptoms or limited necrosis, and the virus replication is usually inhibited at an early stage of infection and/or occurs at undetectable levels (Barker 1996; Ross 1986; Solomon-Blackburn and 
Barker 2001a; Valkonen 1994), whereas HR plants can be recognized by the death of relatively few cells at the site of infection and the formation of a local necrotic lesion, which prevents the infection from spreading further, or systemic necrosis (Dixon et al. 1994; Fraser 1985; Solomon-Blackburn and Barker 2001a).

\subsubsection{Comparison between ER and HR classes}

According to Delhey (1974a\&b) and Valkonen (1994), ER is conferred by the $R$-gene, while HR is conferred by the $N$-gene ( $R$ and $N$ genes are described below). Resistance controlled by Rx genes for PVX (Ross 1986) and by $N y$ genes to PVY (Hutton 1951; Jones 1990) are the best examples on $E R$ and $H R$ in potato, respectively. ER confers resistance to either several strains of the same virus or more than one virus. For example, $R x$ gene confers resistance to all strains of PVX (Ross 1986), while $R y_{\text {sto }}$ confers resistance to PVY, Potato viruses $A$ and $V$ (PVA and PVV) (Barker 1997). Hence, ER is comprehensive. In contrast, $\mathrm{HR}$ in the potato plant is often virus strain-specific. The $N x_{t b r}$ gene confers resistance to PVX strains 1 and 3 (Cadman 1942; Cockerham 1970), while $N b_{t b r}$ gene confers resistance to strain 2 of the same virus (Cockerham 1943\&1970). Previous study has shown that ER in potato against viruses is epistatic over the HR (Bendahmane et al. 1999). For example, cell death does not occur in ER plants (Gilbert et al. 1998; Hämäläinen et al. 1997), but is normally a result of HR (Dangl et al. 1996). However, the finding that potato plants carrying the ER gene $R y_{\text {sto }}$ reacted with limited necrosis as well (Hinrichs et al. 1998) supports old statements suggesting that ER and HR might be somehow connected (Cockerham 1970; Delhey 1974a\&b; Ross 1958). Valkonen's more recent argument (1994) states that both types could be two expression levels of the same type of resistance. Another difference between ER and HR that can be distinguished is that resistance can be expressed in protoplasts derived from ER plants, but not in protoplasts derived from HR plants (Adam et al. 1985\&1986; Barker and Harrison 1984; Baulcombe et al. 1994). For example, the $R x$ mediated resistance to PVX is active in protoplasts carrying the ER Rxl gene (Bendahmane et al. 1995; Köhm et al. 1993).

\subsubsection{Other resistance types in potato}

Resistance to virus movement is another resistance mechanism that can be observed in the potato. In this type, the virus movement through the plant is only impeded (Solomon- 
Blackburn and Barker 2001b), in contrast with ER or HR where the virus is stopped completely at the site of infection, as described above. However, resistance to virus movement has mainly been distinguished in the case of PLRV infection, where the virus infection can be first established in the foliage by aphids' transmission, but the movement to tubers is inhibited (Syller 2003). In this regard, Solomon-Blackburn and Barker (2001b) state that, "HR could also be regarded as resistance to virus movement, because it limits spread within the plant following the initial infection". Finally, a nature resistance response, termed systemic acquired resistance (SAR) (reviewed by Durrant and Dong 2004) has been identified as a secondary host defense; however, such resistance and its corresponding signal transductions will not be discussed in this dissertation.

\section{2. $R$-genes: function and structure}

In most of plant-pathogen cell interactions, resistance or susceptibility of a host towards a particular pathogen is determined by the existence of a host resistance $(R)$ and a pathogen avirulence (avr) gene, a model known as the 'gene-for-gene' concept (Flor 1971). This model has been reported to be compatible with most of the studied single resistance genes in potato plants (Gebhardt and Valkonen 2001). The recognition and interaction between the host $R$-gene and its corresponding avr-gene is a prerequisite to activate the resistance in the plant (Bonas and Lahaye 2002; Martin et al. 2003; Nimchuk et al. 2003). Recently, many plant virus resistance genes have been isolated and cloned, and their nucleotide sequences have been identified. According to Hammond-Kosack and Jones (1997), Martin et al. (2003) and Kang et al. (2005), the structure of a large number of antiviral $R$ genes contains a putative nucleotide binding site (NBS) and a region of leucine-rich repeats (LRRs), referred to as the NBS-LRRs family. The NBS-LRRs proteins differ in the sequence of the Nterminus region. In some proteins, this region may contain a putative-leucine-zipper (LZNBS-LRRs) or coiled-coil (CC-NBS-LRRs), while others may contain a sequence similar to that of the N-terminus of the Drosophila Toll and the mammalian Interleukin (IL)-1 receptor (TIR-NBS-LRRs). Baker et al. (1997) and Gebhardt (1997) indicated that NBS or/and LRRs domains are necessary for any $R$ gene (which functions as a receptor) to recognize and interact with its corresponding $a v r$ gene or to be involved in resistance signaling pathways. To date, three $R$ genes have been cloned and characterized in potato. The $R x 1$ and $R x 2$ genes, which confer ER to PVX, have both been revealed as CC-NBS-LRRs proteins (Bendahmane et al. 1999\&2000), whereas the $Y 1$ gene conferring HR to PVY is found to encode a TIR- 
NBS-LRRs domain (Vidal et al. 2002). It is worth noting that TIR domain is characteristic of the well-known tobacco $N$ gene, which confers HR to TMV (Whitham et al. 1994). More details on classes of plant virus $R$-genes in other species than potato can be found in Kang $\boldsymbol{e t}$ al. (2005) and Soosaar et al. (2005).

\subsection{1. $R$-genes identified in potato and their corresponding avr-genes}

The most adopted standardization of nomenclature of resistant genes in potato is the one proposed by Valkonen et al. (1996). In this nomenclature, the type of resistance is defined by an initial capital letter usually indicating a dominant resistance gene ( $R$ for ER and $N$ for HR), while the virus or strain resisted is determined by a lower case letter. In most cases, an additional subscripted lowercase letter is added to indicate the species where the resistance gene was first found. According to this proposal, a gene synonym conferring ER to PVY in $S$. stoloniferum will take the abbreviation $R y_{\text {sto }}$, while in the case of HR it will take $N y_{\text {sto }} . R$ genes conferring ER or HR to PVX, PVY, PVV or PVA in potato have been identified in different Solanum species (reviewed by Solomon-Blackburn and Barker 2001b). In $S$. tuberosum, all identified $R$-genes were introduced from various wild Solanum species via conventional breeding (Bradshaw and Mackay 1994; Ross 1986); however, no host resistance gene to TRV has been reported yet, in either wild or cultivated Solanum species.

Based on the 'gene-for-gene' model described above, several studies have shown that resistance in plants is elicited by specific virus-encoded $a v r$ gene(s). As for potato viruses, the PVX-CP has been found to elicit more than one resistance gene, the ER $R x 1$ and $R x 2$ genes (Bendahmane et al. 1995), as well as the HR $N x$ gene (Santa Cruz and Baulcombe 1993), while the PVX-MP has been found to elicit $N b$-mediated hypersensitive cell death (Malcuit et al. 1999). The NIa protease of PVY has been found to elicit the ER Ry gene (Mestre $\boldsymbol{e t}$ al. 2000). In most cases, one or more amino acids in the viral elicitor protein are responsible for eliciting resistance in potato (described later).

\subsubsection{Assays to identify $R$ - and $a v r$-genes}

A number of assays have been widely used to identify and functionally characterize plant virus-resistance genes, and a few of them can also be used to identify corresponding elicitor proteins. Producing transgenic plants transformed with the candidate $R$-gene, and then challenging these plants with the virus, is the most common assay used to identify $R$-genes in 
potato. For example, transgenic potato and tobacco plants transformed with the $R x$ transgene have been tested for resistance to inoculation with PVX (Bendahmane et al. 1999). Also, transgenic potato plants transformed with the $Y-1$ gene have been tested for resistance to PVY ${ }^{\circ}$ strain, PVA and PVV (Vidal et al. 2002). Another assay is based on transiently expressing the candidate gene, either by an Agrobacterium or a biolistic system, into plants harboring the elicitor gene. Agrobacterium-medited transient expression has been used to identify the $R x 2$ gene in transgenic tobacco leaves expressing the PVX CP elicitor of $R x 2$ mediated resistance (Bendahmane et al. 2000).

Similarly, Agrobacterium-medited transient expression assay has been used to identify the PVY-encoded NIa proteinase, the elicitor of $R y$-mediated resistance, by transiently expressing this NIa gene in resistance $(R y)$ and susceptible (ry) potato plants (Mestre et al. 2000). On the other hand, the PVX-MP, the elicitor of $N b$-mediated cell death in potato, has been identified using a biolistic transient expression (particle bombardment) system (Malcuit et al. 1999). Site-directed mutagenesis (SDM) technique, based on introducing several mutations into the gene of interest, has been used to identify the domain in the CP of PVX that possesses the elicitor activity of $R x$-mediated resistance (Bendahmane et al. 1995).

\section{Breeding for virus-resistance in $S$. tuberosum}

\section{1. $\underline{\text { Background }}$}

Breeding for resistance against pathogens in $S$. tuberosum was started more than 70 years ago. In the case of virus diseases, initial attempts were based on conventional breeding in order to obtain new varieties harboring one or more resistance genes by crossing resistant wild potatoes with susceptible domestic cultivars; however, this introgression of resistance may take a few to many years due to the extensive backcrossing required, and in some cases it can be ineffective due to the introduction of undesirable wild traits (Gebhardt and Valkonen 2001; Solomon-Blackburn and Barker 2001a). Therefore, it is very beneficial before starting any breeding program for a particular resistance to have comprehensive genetic and molecular information on both the resistance of interest and the virus, such as types of resistance (described above), resistance inheritance and number of involved host genes, specific viral sequence (motif) eliciting resistance, and durability of resistance. 
ER or HR types to TRV infection have been reported in several potato cultivars and clones based on spraing development in tubers (Dale and Solomon 1988; Mojtahedi et al. 2001; Robinson 2004; Robinson et al. 2004; Xenophontos et al. 1998). As mentioned previously, ER is comprehensive in comparison with HR; therefore, breeding for ER to TRV is more reasonable than breeding for HR in potato. Nevertheless, breeding for HR is also important, as both ER and HR are proven to be effective, quite durable and simply inherited (as described below) (Solomon-Blackburn and Barker 2001b).

\subsection{Inheritance}

Usually, three different modes of inheritance for virus-resistance genes can be observed: dominant, incomplete dominant, and recessive. However, several reports have indicated that resistance to potato viruses expressed either as ER or HR, is inherited monogenically (Kang et al. 2005; Valkonen et al. 1996). Genes ( $R x, N x$ and $N b)$ conferring resistance to PVX have all been revealed as single dominant genes (Cockerham 1970; Mills 1965; Solomon 1985). Resistance to PVY is a monogenic dominant or incomplete dominant in Solanum (Provvidenti and Hampton 1992). In contrast, recessive inheritances have been reported in the potato plant, such as the $r a$ gene that prevents the systemic infection of PVA in graftinoculated diploid potatoes (Hämäläinen et al. 2000). In some cases, the resistance to more than one virus can be governed by one dominant gene. For example, the ER to PVY and Tobacco etch virus (TEV) in Solanum plants are governed by one dominant gene, the $R y_{\text {sto }}$. (Hinrichs-Berger et al. 2000).

\subsection{Mapping $R$-genes}

Inheritance studies of pathogen-resistance genes, in general, require a molecular mapping, which defined as determining the position of a resistance gene on a certain chromosome. Mapping of potato $R$-gene(s) conferring resistance to pathogen(s) is, somehow, complicated due to the different ploidy levels and heterozygous of potato species (as mentioned above). To map a particular $R$-gene, DNA molecular markers have to be developed, and subsequently linkage maps have to be constructed. One recent report has indicated that linkage maps have previously been helpful in locating the genes controlling monogenic or polygenic resistance to various pathogens on the 12 potato chromosomes (Gebhardt and Valkonen 2001). Among the various types of molecular markers (reviewed by Collard et al. 2005), 
'restriction fragment length polymorphism' (RFLP), 'random amplified polymorphic DNA' (RAPD), and 'amplified fragment length polymorphism' (AFLP) are the most widely used markers for mapping the position of several genes conferring virus resistance in potato. The $R x 1$ and $R x 2$ genes were mapped at two different positions, on chromosome XII and V, respectively (Ritter et al. 1991), while $R y_{a d g}$ and $R y_{\text {sto, }}$ genes were both mapped on chromosome XI (Brigneti et al. 1997; Hämäläinen et al. 1997). In some cases, two $R$-genes with different types of resistance to the same virus might have found to be located on one chromosome, as in a case of resistance to PVX, where two ER $R x 2$ and HR $N b_{t b r}$ genes were mapped to the same region on chromosome V (De Jong et al. 1997; Ritter et al. 1991). The larger number of antiviral $R$-genes in the potato has been mapped to chromosome XI, while only one gene has been mapped on chromosome IX: the $N x_{p h u}$, which confers HR to PVX (Tommiska et al. 1998). More details on molecular mapping of potato virus resistance genes can be found in Gebhardt 2005 and Gebhardt and Valkonen (2001) and SolomonBlackburn and Barker (2001a).

Finally, DNA molecular markers can also help in determining the relationship between resistance genes (allelic or linked), and in developing marker-assisted selection (MAS) and quantitative trait loci (QTL); however, these techniques will not be discussed here.

\subsection{Durability of resistance}

Plant viruses often attempt to create a single or multiple mutations in their avr-gene in order to overcome host resistance, resulting in what are called 'resistance-breaking' (RB) strains (reviewed by Harrison 2002). These changes in the nucleotide sequence may occur either by recombination or through convergent evolution of the virus (Harrison 2002; Malcuit et al. 2000). A recent study (Garcia-Arenal and McDonald 2003) has stated that "resistance is usually considered durable if no resistance breaking has been reported or if it has been effective for 25 years or more". To date, no RB strain of PVY has been reported in the potato, which proves the high durability of this gene. In contrast, the PVX strain HB is able to overcome all known resistance genes (Querci $\boldsymbol{e t}$ al. 1993). Two amino acid residues unique to this strain have been found to be responsible in overcoming the $R x$-mediated resistance (Gouldin et al. 1993). Recently, a TRV strain PpO85M was reported to overcome the 
resistance in potato cv. 'Bintje' (which is known to be resistant to nematode infection with TRV), and to cause spraing symptoms in daughter plants (Robinson 2004).

Usually, RB strains have lower fitness than 'wild-type' strains, as any mutation may affect the appearing and spreading of the RB strain in the absence of the host resistance (Harrison 2002). In general, $E R$ and $H R$ in potato are reported to be quite durable (Solomon-Blackburn and Barker 2001b). Finally, it seems that resistance durability and modes of inheritance and/or the number of involved resistance genes are, somehow, connected. RB isolates are reported more frequently with dominant, single gene resistance than with recessive or polygenic resistance (Fraser 1990). This has been attributed to the difficulty of a virus isolate to overcome multiple resistances at once (Hammond 1998).

\section{RNA Silencing in plants}

Like antiviral host $R$-genes, 'RNA silencing' is another natural antiviral host defense activated in plants as a response to virus infection, known as post-transcriptional gene silencing (PTGS), and based mainly on a nucleotide sequence-specific RNA degradation mechanism (Baulcombe 2002; Mlotshwa et al. 2002; Vance and Vaucheret 2001; Voinnet 2001). RNA silencing is conserved among most eukaryotic organisms. In addition to PTGS, it is also known as quelling in fungi (Nakayashiki 2005), and RNA interference (RNAi) in animals (Li and Ding 2005). Besides that different pathways or variant mechanisms of RNA silencing have been reported (Baulcombe 2004); however, double-stranded RNA (dsRNA) is the main trigger of RNA silencing machinery in various organisms, as well as a potential target in a homology-sequence manner (Bass 2000; Meister and Tuschl 2004). Accordingly, replicating RNA viruses, transposons, viral and non-viral transgenes, transgenes arranged as inverted repeats or synthetic dsRNA, can all induce silencing. When a viral vector, carrying a specific gene homologous to endogenous host gene, is introduced to the plant, both the virus and the endogenous host gene are silencing. This process is known as 'virus-induced gene silencing' (VIGS) (reviewed by Baulcombe 1999; Burch-Smith et al. 2004), whereas silencing induced by a viral or non-viral transgene with a homologous to endogenous gene is called 'transgene-induced gene silencing' (reviewed by Vaucheret et al. 1998). It is worth noting that, in addition to its antiviral defense mechanism, RNA silencing is also involved in protecting plant genome from transposons, regulating gene expression, and working at many other levels; however, these processes will not be discussed here. 


\subsection{RNA silencing machinery and components}

The mechanism of RNA silencing in plants is shown in Fig. (2). Unless other dsRNAs are introduced, virus replication directly produces dsRNA by its RNA dependent RNA polymerase (RdRp) as a main inducer (Vance and Vaucheret 2001). On the other hand, viral mRNA may be recognized by the plant as well, and converted into dsRNA by plant RdRp (Ahlquist 2002). The recognized dsRNA is then cleaved by a double-stranded specific RNaseIII-like enzyme termed 'DICER' (Bernstein et al. 2001) into 21-26 nt dsRNA fragments with 2-3 nt at 3' overhanging ends, referred to as small interfering RNA (siRNA), corresponding to both sense and antisense strands of the target gene (Elbashir et al. 2001; Hamilton and Baulcombe 1999). The generated siRNA is unwinding, and the antisense strand is incorporated into a multi-subunit ribonuclease, named RNA-induced silencing complex (RISC). This association guides the protein-siRNA complex to find and degrade the targeted mRNA, which is already transcribed from the native target gene and shares a homology sequences with the siRNA (Hammond et al. 2000; Martinez and Tuschl 2004; Zamore et al. 2000). On the other hand, for the continuance and spread of RNA silencing, plant RdRp may use siRNA as a primer on homologous mRNAs and synthesize dsRNA, which is then processed by DICER into secondary siRNA. This process is termed 'transitive RNA silencing' (Himber et al. 2003; Vaistij et al. 2002). In this regard, several studies have shown that RNA silencing is a mobile silencing signal; it is first initiated locally (in a few cells) before long cell-to-cell movement processes begin the spreading of silencing throughout the whole plant (non-cell-autonomous) (Mlotshwa et al. 2002; Palauqui et al. 1997; Voinnet and Baulcombe 1997). Two size classes of siRNA are generated. A predominant short 21-22 nt operates with local RNA silencing and correlates with mRNA degradation, and long 24-26 nt, is found only with long-distance systemic spread, but not correlated with mRNA degradation (Hamilton et al. 2002).

\subsection{Plant viral suppressor proteins of RNA silencing}

To overcome the antiviral RNA silencing, most plant viruses encode for a gene which is able to interfere with the silencing machinery, referred to as "viral suppressor of RNA silencing" (VSR) (Li and Ding 2006). Many plant VSR proteins have been identified, belonging to several different viral genera and species (reviewed by Li and Ding 2006; Moissiard and Voinnet 2004; Voinnet 2005). They all possess high diversity and share no sequence 


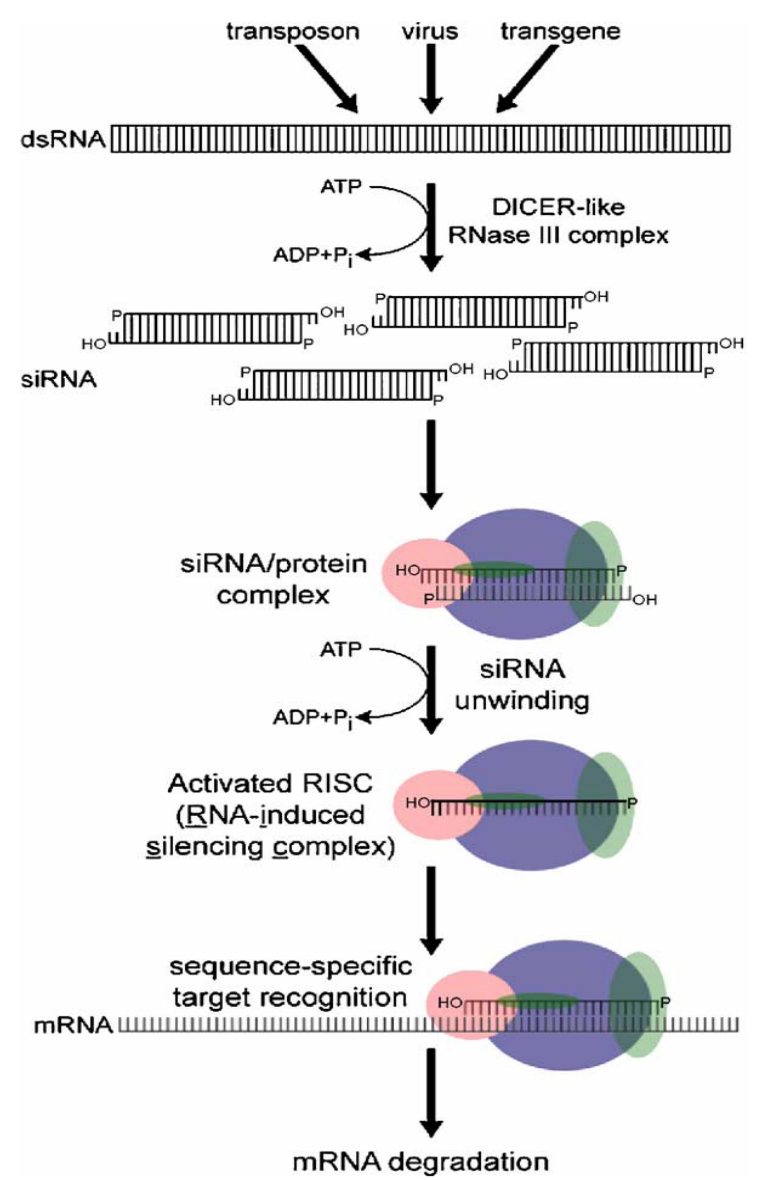

Fig. (2). RNA silencing mechanism. From Roth et al. (2004).

homology with each other (Voinnet 2001). This diversity in sequence reflects their range in suppression efficiency, targets, and biological functions. Different strategies are adopted by plant VSR proteins, in which they target different steps of the RNA silencing process. Some proteins are able to suppress RNA silencing at an early initiation step either by eliminating associated siRNA (probably interfering with DICER), such as the CP (P38) from Carmovirus (Qu et al. 2003), or binding (sequestering) generated siRNA to prevent its accumulation, such as the P19 from Tombusvirus (Lakatos et al. 2004; Silhavy et al. 2002). It has been recently suggested that dsRNA binding is a general silencing suppression strategy adopted by several plant VSR proteins (Mérai et al. 2006). Other plant VSR proteins work at later stage by targeting maintenance step, hence reducing the accumulation of siRNA, such as the HCPro of Potyvirus (Anandalakshmi et al. 1998; Brigneti et al. 1998; Llave et al. 2000). Interestingly, HC-Pro protein has been found to affect plant endogenous micro (mi) RNA required for regulation of gene expression by enhancing its accumulation, or even by blocking the function of miRNA. Hence, it interferes with symptom expression and 
development of the plant (Chapman et al. 2004; Kasschau et al. 2003; Mallory et al. 2002). Moreover, HC-Pro has also been found to interact with a host protein involved in regulation of RNA silencing in the plant (Anandalakshmi et al. 2000). On the other hand, some plant VSR proteins may have no effect on local PTGS; they instead prevent the spread of the systemic silencing signal to newly developed leaves, such as the $2 \mathrm{~b}$ from Cucumovirus (Brigneti et al. 1998; Guo and Ding, 2002). In addition to silencing suppression, many plant VSR proteins have been found to be involved in other biological functions of the virus, such as viral replication and/or pathogenicity. For example, more than $30 \%$ of the identified plant VSR function as pathogenicity determinants, including TRV $16 \mathrm{~K}$ protein (Brigneti et al. 1998; Li et al. 1999; Liu et al. 2002; Voinnet et al. 1999).

\subsection{Assays to identify plant VSR}

Several reliable techniques have been widely applied to investigate the suppression activity of plant viral proteins. One of the most commonly used methods is the Agrobacterium-mediated transient expression assay, in which the candidate suppressor can be co-infiltrated with another gene (usually a reporter gene) homologous to an endogenous gene in the plant (Johansen and Carrington 2001; LIave et al. 2000; Voinnet et al. 2000). Plant VSR proteins can also be identified by their ability to reverse silencing when expressed in presilenced plants, an assay known as 'reversal of silencing assay' (Brigneti et al. 1998). Several works have adopted stable expression assay using a transgenic line constantly expressing the candidate gene. These expressing plants are either crossed with other transgenic line (usually silenced for a reporter gene) to study the mechanism followed by the suppressor (Anandalakshmi et al. 2000; Kasschau et al. 2003), or by grafting a rootstock from the expressing plant on the top of it (non-silenced scions) to investigate the effect of the suppressor on the systemic silencing signal (Palauqui et al. 1997).

\section{Requirements for efficient silencing suppression by plant VSR}

Many of the identified plant VSR proteins have been found to require other associated activities, which are indispensable for their efficient suppression of RNA silencing defense machinery. 


\subsection{Subcellular localization}

Generally, nuclear and/or cytoplasmic localization is the most investigated process for plant VSR proteins. Transport of proteins into and out of the nucleus is reviewed by Görlich and Kutay (1999) and Izaurralde and Adam (1998). For nuclear targeting, the protein must contain a short region that directs the protein to the nucleus, termed nuclear localization signal (NLS). NLSs are enriched in basic amino acids, arginine [R] and lysine [K], but have no strict consensus sequence (Dingwall and Laskey 1991). Two types of NLSs are known. A classical monopartite NLS motif consists of a short stretch of basic amino acids; the best example is the motif "PKKKRKV" from the Simian virus 40 Large T antigen (Kalderon et al. 1984). The second type is a non-classical bipartite NLS motif consisting of two stretches of basic amino acids separated by a spacer region of any ten amino acids, such as the motif "KRPAATKKAGQAKKKK" found in Xenopus nucleoplasmin protein (Robbins et al. 1991). Nuclear localization of some plant VSR, with the help of, at least, one NLS, has been found to be indispensable for efficient suppression of PTGS, such as the Cucumovirus $2 \mathrm{~b}$ protein (Lucy et al. 2000). Other plant VSR proteins do not localize into the nucleus, instead localizing predominantly in the cytoplasm, either freely distributed or associated with a specific organelle in the cell. For example, the Hordeivirus CRP $\gamma \mathrm{b}$ has been found to be localized to the peroxisomes; however, this targeting was dispensable for its suppression activity (Yelina et al. 2005). On the other hand, an amino acid region in the P126 suppressor protein of Tobamovirus has been found to function as an NLS, although the entire protein was found localized in the cytoplasm, associated with the endoplasmic reticulum (Figueira $\boldsymbol{e t}$ al. 2002).

In addition to NLS, the nuclear export signal (NES) motif is required to transport protein out of the nucleus. NES is enriched in hydrophobic residues (usually leucine), and share no similarity to NLS (Gerace, 1995). The best example of this is the Rev protein of Human immunodeficiency virus (HIV-Rev) (Kalland et al. 1994; Meyer and Malim 1994). Interestingly, some proteins may have a sequence that functions as both import and export signal, as in the M9 sequence of the heterogeneous nuclear RNP (hnRNP) A1 protein in eukaryotic cells (Siomi and Dreyfuss 1995). No NES has been reported yet for any of the identified plant VSR proteins. 


\section{2. $\underline{\text { Other specific motifs }}$}

Motifs, including 'zinc-fingers' or 'coiled-coil', have been found to participate significantly in the suppression activity of some plant VSR. For example, the zinc-finger motif in the suppressor C2 protein of Begomovirus is necessary for DNA-binding, which in turn is required for its pathogenicity, as well as suppression of PTGS (Van Wezel et al. 2002\&2003). The coiled-coil motif in $\mathrm{P} 15$ of Pecluvirus has also been found indispensable for efficient suppression of PTGS (Dunoyer et al. 2002). Finally, it can be noticed that resemblance or difference between different types of plant VSR is not only in their suppression mechanisms, but also in their requirements to achieve their counter-attack task in a more complete manner.

\section{Justifications and objectives}

Spraing disease in potato caused by TRV is considered a big problem for virus-resistance breeding programs as well as the industrial sector due to its effect on tuber quality. Distinguishing between resistant and susceptible potato plants has now become timeconsuming and laborious because of the requirement to ascertain that the tubers are free from the virus, considering the difficulty of recovering the virus from the tubers. Screening for resistance to spraing in the potato, based only on exposure for nematode infection in naturally infested soils, is slow and laborious and often yields varying results due to the inconsistent conditions. Additionally, such kind of screening is not a reliable biotest, as plants might become fully infected but produce no spraing. Since the basis of resistance to TRV in potato is unknown, the characterization of different host resistance mechanisms to TRV and the determination of the viral avr-gene eliciting the resistance is a challenge. The finding that a resistance-breaking isolate of TRV is able to overcome the resistance in cv. 'Bintje' (Robinson 2004), prompted us to investigate this isolate in more details. On the other hand, the suppression activity of $16 \mathrm{~K}$ gene encoded by TRV RNA1 has been studied only in Drosophila cells (Reavy et al. 2004). Only two studies on subcellular localization of 16K have been reported (Angenent et al. 1989; Liu et al. 1991), but the results obtained by these studies did not present a persuasive answer on the nuclear targeting of this protein. Therefore, the work presented in this dissertation was carried out to achieve the following objectives: 
- To characterize the different resistance responses to TRV-PpK20 in three potato cultivars, known to be susceptible or resistant to natural nematode infection with TRV-PpK20, using two different leaf-inoculation methods.

- To compare between host-resistance responses to the avirulence PpK20 and the resistance-breaking PpO85M isolates following mechanical leaf-inoculation.

- To determine the viral avr-gene within TRV genome.

- To investigate the silencing suppression activity of $16 \mathrm{~K}$ protein in planta.

- To functionally characterize motifs within $16 \mathrm{~K}$ related to its suppression of RNA silencing activity using mutagenesis approach.

- To determine the subcellular localization of $16 \mathrm{~K}$ protein using confocal laser scanning microscopy (CLSM) analysis of agro-expressed fluorescent marker protein-tagged fusions.

The various methods applied and the results acquired from this study are presented in two independent manuscripts (Chapters 2-3). More arguments and arising questions are discussed in the general discussion (Chapter 4).

\section{REFERENCES}

Adams, S. E., R. A. C. Jones, and R. H. A. Coutts. 1985. Infection of protoplasts derived from potato shoot cultures with Potato virus X. J. Gen. Virol. 66:1341-1346.

Adams, S. E., R. A. C. Jones, and R. H. A. Coutts. 1986. Expression of Potato virus X resistance gene $R x$ in potato leaf protoplasts. J. Gen. Virol. 67:2341-2345.

Ahlquist, P. 2002. RNA-dependent RNA polymerases, viruses, and RNA silencing. Science 296:1270-1273.

Anandalakshmi, R., R. Marathe, X. Ge, J. M. Herr, Jr., C. Mau, A. Mallory, G. J. Pruss, L. Bowman, and V. B. Vance. 2000. A calmodulin-related protein that suppresses post-transcriptional gene silencing in plants. Science 290:142-144. 
Anandalakshmi, R., G. J. Pruss, X. Ge, R. Marathe, A. Mallory, T. H. Smith, and V. B. Vance. 1998. A viral suppressor of gene silencing in plants. Proc. Natl. Acad. Sci. USA 95:13079-13084.

Angenent, G. C., H. J. M. Linthorst, A. F. van Belkum, B. J. C. Cornelissen, and J. F. Bol. 1986. RNA-2 of Tobacco rattle virus strain TCM encodes an unexpected gene. Nucleic Acid Res. 14:4673-4682.

Angenent, G. C., H. B. M. Verbeek, and J. F. Bol. 1989. Expression of the 16K cistron of Tobacco rattle virus in protoplasts. Virology 169:305-311.

Baker, B., P. Zambryski, B. Staskawicz, and S. P. Dinesh-Kumar. 1997. Signaling in plant-microbe interaction. Science 276:726-733.

Barker, H. 1996. Inheritance of resistance to Potato viruses $Y$ and $A$ in progeny obtained from potato cultivars containing gene $R y$ : evidence for a new gene for extreme resistance to PVA. Theor. Appl. Genet. 93:710-716.

Barker, H. 1997. Extreme resistance to Potato virus $V$ in clones of Solanum tuberosum that are also resistant to Potato viruses $Y$ and $A$ : evidence for a locus conferring broad-spectrum resistance. Theor. Appl. Genet. 95:1258-1262.

Barker, H., and B. D. Harrison. 1984. Expression of genes for resistance to Potato virus $Y$ in potato plants and protoplasts. Ann. Appl. Biol. 105:539-545.

Bass, B. L. 2000. Double-stranded RNA as a template for gene silencing. Cell 101:235-238.

Baulcombe, D. C. 1999. Fast forward genetics based on virus-induced gene silencing. Curr. Opin. Pl. Biol. 2:109-113.

Baulcombe, D. C. 2002. RNA silencing. Curr. Biology 12:R82-R84.

Baulcombe, D. C. 2004. RNA silencing in plants. Nature 431:356-363.

Baulcombe, D. C., J. E. Gilbert, M. Goulden, B. A. Köhm, and S. Santa Cruz. 1994. Molecular biology of resistance to Potato virus $X$ in potato. Biochem. Soc. Symp. 60:207218.

Beczner, L., J. Horvath, I. Romhanyi, and H. Förster. 1984. Studies on the etiology of tuber necrotic ringspot disease in potato. Potato Res. 27:339-352. 
Bendahmane, A., G. Farnham, P. Moffett, and D. C. Baulcombe. 2002. Constitutive gainof-function mutants in a nucleotide binding site-leucine rich repeat protein encoded at the $R x$ locus of potato. Plant J. 32:195-204.

Bendahmane, A., K. Kanyuka, and D. C. Baulcombe. 1999. The $R x$ gene from potato controls separate virus resistance and cell death responses. Plant Cell 11:781-791.

Bendahmane, A., B. A. Köhm, C. Dedi, and D. C. Baulcombe. 1995. The coat protein of Potato virus $X$ is a strain-specific elicitor of $R x l$-mediated virus resistance in potato. Plant J. 8:933-941.

Bendahmane, A., M. Querci, K. Kanyuka, and D. C. Baulcombe. 2000. Agrobacterium transient expression system as a tool for the isolation of disease resistance genes: application to the $R x 2$ locus in potato. Plant J. 21:73-81.

Bernstein, E., A. A. Caudy, S. M. Hammond, and G. J. Hannon. 2001. Role for bidentate ribonuclease in the initiation step of RNA interference. Nature 409:363-366.

Bonas, U., and T. Lahaye. 2002. Plant disease resistance triggered by pathogen-derived molecules: refined models of specific recognition. Curr. Opin. Microbiol. 5:44-50.

Bradshaw, J. E., and G. R. Mackay. 1994. Breeding strategies for clonally propagated potatoes. In: J. E. Bradshaw and G. R. Mackay (eds.). Potato Genetics. CAB International, Wallingford, pp. 467-497.

Brigneti, G., J. Garcia-Mas, and D. C. Baulcombe. 1997. Molecular mapping of the Potato virus $Y$ resistance gene $R y_{\text {sto }}$ in potato. Theor. Appl. Genet. 94:198-203.

Brigneti, G., O. Voinnet, W. X. Li, L. H. Ji, S. W. Ding, and D. C. Baulcombe. 1998. Viral pathogenicity determinants are suppressors of transgene silencing in Nicotiana benthamiana. EMBO J. 17:6739-6746.

Brown, E. B., and G. B. Sykes. 1973. Control of Tobacco rattle virus (spraing) in potatoes. Ann. Appl. Biol. 75:462-464.

Burch-Smith, T. M., J. C. Anderson, G. B. Martin, and S. P. Dinesh-Kumar. 2004. Applications and advantages of virus-induced gene silencing for gene function studies in plants. Plant J. 39:734-746.

Cadman, C. H. 1942. Autotetraploid inheritance in the potato: some new evidence. J. Genet. $44: 33-51$. 
Chapman, E. J., A. I. Prokhnevsky, K. Gopinath, V. V. Dolja, and J. C. Carrington. 2004. Viral RNA silencing suppressors inhibit the microRNA pathway at an intermediate step. Genes Dev. 18:1179-1186.

Cockerham, G. 1943. Potato breeding for virus resistance. Ann. Appl. Biol. 30:105-108.

Cockerham, G. 1970. Genetical studies on resistance to Potato viruses $X$ and Y. Heredity 25:309-348.

Collard, B. C. Y., M. Z. Z. Jahufer, J. B. Brouwer, and E. C. K. Pang. 2005. An introduction to markers, quantitative trait loci (QTL) mapping and marker-assisted selection for crop improvement. Euphytica 142:169-196.

Correll, D. S. 1962. The potato and its wild relatives: section Tuberarium of the genus Solanum. Texas Research Foundation, Renner, Texas. 606 pp.

Dale, M. F. B., D. J. Robinson, D. W. Griffiths, D. Todd, and H. Bain. 2000. Effects of tuber-borne M-type strain of Tobacco rattle virus on yield and quality attributes of potato tubers of the cultivar Wilja. Eur. J. P1. Pathol. 106:275-282.

Dale, M. F. B., and R. M. Solomon. 1988. A glasshouse test to assess the sensitivity of potato cultivars to Tobacco rattle virus. Ann. Appl. Biol. 112:225-229.

Dangl, J. L., R. A. Dietrich, and M. H. Richberg. 1996. Death don't have no mercy: cell death programs in plant-microbe interactions. Plant Cell 8:1793-1807.

De Bokx, J. A., and J. P. H. van der Want. 1987. Viruses of potatoes and seed potato production. PUDOC, Wageningen, The Netherland, 259 pp.

De Jong, W., A. Forsyth, D. Leister, C. Gebhardt, D. C. Baulcombe. 1997. A potato hypersensitive resistance gene against Potato virus $X$ maps to a resistance gene cluster on chromosome 5. Theor. Appl. Genet. 95:246-252.

Delhey, R. 1974a. Zur Nature der extremen Virusresistenz bei der Kartoffel. I. Das X-Virus. Phytopathol. Z. 80:97-119.

Delhey, R. 1974b. Zur Nature der extremen Virusresistenz bei der Kartoffel. II. Das Y-Virus. Phytopathol. Z. 82:163-168.

Dingwall, C., and R. Laskey. 1991. Nuclear targeting sequences - a consensus? Trends Biochem. Sci. 16:478-481. 
Dixon, R. A., M. J. Harrison, and C. J. Lamb. 1994. Early events in the activation of plant defense responses. Ann. Rev. Phytopathol. 32:479-501.

Dodds, K. S. 1962. Classification of cultivated potatoes. In: D. S. Correll (ed.). The Potato and its Wild Relatives: Section Tuberarium of the Genus Solanum. Texas Research Foundation, Renner, Texas, pp. 517-539.

Dunoyer, P., S. Pfeffer, C. Fritsch, O. Hemmer, O. Voinnet, and K. E. Richards. 2002. Identification, subcellular localization and some properties of a cysteine-rich suppressor of gene silencing encoded by Peanut clump virus. Plant J. 29:555-567.

Durrant, W. E., and X. Dong. 2004. Systemic acquired resistance. Annu. Rev. Phytopathol. 42:185-209.

Elbashir, S. M., W. Lendeckel, and T. Tuschl. 2001. RNA interference is mediated by 21and 22-nucleotide RNAs. Genes Dev. 15:188-200.

Figueira, A. dos R., S. Golem, S. P. Goregaoker, and J. N. Culver. 2002. A nuclear localization signal and a membrane association domain contribute to the cellular localization of the Tobacco mosaic virus 126-kDa replicase protein. Virology 301:81-89.

Flor, H. H. 1971. Current status of the gene-for-gene concept. Annu. Rev. Phytopathol. 9:275-296.

Fraser, R. S. S. 1985. Mechanisms of genetically controlled resistance and virulence: virus diseases. In: R. S. S. Fraser (ed.). Mechanisms of Resistance to Plant Diseases. Martinus Nijhoff/Dr W. Junk, Dordrecht, pp. 143-196.

Fraser, R. S. S. 1990. The genetics of resistance to plant viruses. Annu. Rev. Phytopathol. 28:179-200.

Garcia-Arena, F., and B. A. McDonald. 2003. An analysis of the durability of resistance to plant viruses. Phytopathol. 93:941-952.

Gebhardt, C. 1997. Plant genes for pathogen resistance - variation on a theme. Trends Pl. Sci. 2:243-244.

Gebhardt, C. 2005. Potato genetics: molecular maps and more. In: H. Lörz, and G. Wenzel (eds.). Molecular Marker Systems in Plant Breeding and Crop Improvement. Springer, NY, U.S.A., pp. 215-228. 
Gebhardt, C., and J. P. T. Valkonen. 2001. Organization of genes controlling disease resistance in the potato genome. Annu. Rev. Phytopathol. 39:79-102.

Gerace, L. 1995. Nuclear export signals and the fast track to the cytoplasm. Cell 82:341-344.

Gilbert, J., C. Spillane, T. A. Kavanagh, and D. C. Baulcombe. 1998. Elicitation of $R x$ mediated resistance to PVX in potato does not require new RNA synthesis and may involve a latent hypersensitive response. Mol. Plant-Microbe Interact. 8:833-835.

Görlich, D., and U. Kutay. 1999. Transport between the cell nucleus and the cytoplasm. Annu. Rev. Cell Dev. Biol. 15:607-660.

Gou, H. S., and S. W. Ding. 2002. A viral protein inhibits the long range signaling activity of the gene silencing signal. EMBO J. 21:398-407.

Goulden, M. G., B. A. Köhm, S. S. Cruz, T. A. Kavanagh, and D. C. Baulcombe. 1993. A feature of the coat protein of Potato virus $X$ affects both induced virus resistance in potato and viral fitness. Virology 197:293-302.

Goulden, M. G., G. P. Lomonossoff, K. R. Wood, and J. W. Davies. 1991. A model for the generation of Tobacco rattle virus (TRV) anomalous isolates: Pea early-browning virus RNA2 acquires TRV sequences from both RNA1 and RNA2. J. Gen. Virol. 72:1751-1754.

Hämäläinen J. H., T. Kekarainen, C. Gebhardt, K. N. Watanabe, and J. P. T. Valkonen. 2000. Recessive and dominant genes interfere with the vascular transport of Potato virus $A$ in diploid potatoes. Mol. Plant-Microbe Interact. 13:402-412.

Hämäläinen J. H., K. N. Watanabe, J. P. T. Valkonen, A. Arihara, and R. L. Plaisted. 1997. Mapping and marker-assisted selection for a gene for extreme resistance to Potato virus $Y$. Theor. Appl. Genet. 94:192-197.

Hamilton, W. D. O., and D. C. Baulcombe. 1989. Infectious RNA produced by in vitro transcription of a full-length Tobacco rattle virus RNA-1 cDNA. J. Gen. Virol. 70:963-968.

Hamilton, A. J., and D. C. Baulcombe. 1999. A species of small antisense RNA in posttranscriptional gene silencing in plants. Science 286:950-952.

Hamilton, A. J., O. Voinnet, L. Chappell, and D. C. Baulcombe. 2002. Two classes of short interfering RNA in RNA silencing. EMBO J. 21:4671-4679. 
Hammond, J. 1998. Resistance to plant viruses-an overview. In: A. Hadidi, R. K. Khetarpal, and H. Koganezawa (eds.). Plant Virus Disease Control., APS Press, St. Pual, Minnesota, U.S.A., pp. 163-171.

Hammond, S. M., E. Bernstein, D. Beach, and G. J. Hannon. 2000. An RNA-directed nuclease mediates post-transcriptional gene silencing in Drosophila cells. Nature 404:293296.

Hammond-Kosack, K. E., and J. D. G. Jones. 1997. Plant disease resistance genes. Annu. Rev. Pl. Physiol. P1. Mol. Biol. 48:575-607.

Harrison, B. D. 1973. Pea early-browning virus. CMI/AAB Description of Plant Viruses, no. 120.

Harrison, B. D. 1977. Ecology and control of viruses with soil-inhabiting vectors. Annu. Rev. Phytopathol. 15:331-360.

Harrison, B. D. 2002. Virus variation in relation to resistance-breaking in plants. Euphytica 124:181-192.

Harrison, B. D., and D. J. Robinson. 1978. The Tobraviruses. Adv. Virus Res. 23:25-77.

Harrison, B. D., and D. J. Robinson. 1981. Tobraviruses. In: E. Kurstak (ed.), Handbook of Plant Virus Infection and Comparative Diagnosis. Elsevier/North-Holland Biomedical Press, Amsterdam, pp. 515-540.

Harrison, B. D., D. J. Robinson, W. P. Mowat, and G. H. Duncan. 1983. Comparison of nucleic acid hybridization and other tests for detecting Tobacco rattle virus in narcissus plants and potato tubers. Ann. Appl. Biol. 102:331-338.

Hawkes, J. G. 1990. The potato: evolution, biodiversity and genetic resources. London, Belhaven.

Hernández, C., P. B. Visser, D. J. F. Brown, and J. F. Bol. 1997. Transmission of Tobacco rattle virus isolate $\mathrm{PpK} 20$ by its nematode vector requires one of the two non-structural genes in the viral RNA 2. J. Gen. Virol. 78:465-467.

Himber, C., P. Dunoyer, G. Moissiard, C. Ritzenthaler, and O. Voinnet. 2003. Transitivity-dependent and -independent cell-to-cell movement of RNA silencing. EMBO J. 22:4523-4533. 
Hinrichs, J., S. Berger, and J. G. Shaw. 1998. A hypersensitive response-like mechanism is involved in resistance of potato plants bearing the $R y_{\text {sto }}$ gene to the potyviruses Potato virus $Y$ and Tobacco etch virus. J. Gen. Virol. 79:167-176.

Hinrichs-Berger, J., H. Junghans, and H. Buchenauer. 2000. Early selection for extreme resistance to Potato virus $Y$ and Tobacco etch virus in potato using a $\beta$-glucuronidasetagged virus. P1. Breeding 119:319-323.

Howard, H. W. 1970. Genetics of the potato. Logos Press, London.

Hull, R. 2002. Matthew's Plant Virology. Academic Press, London, p.1001.

Hutton, E. M. 1951. Possible genotypes conditioning virus resistance in the potato and tomato. J. Aust. Inst. Agric. Sci. 17:132-138.

Izaurralde, E., and S. Adam. 1998. Transport of macromolecules between the nucleus and the cytoplasm. RNA 4:351-364.

Jeffries, C., H. Barker, and S. M. P. Khurana. 2005. Potato viruses (and viroids) and their management. In: Handbook of Potato Production, Improvement and Post-harvest Management, J. Gopal and S. M. P. Khurana, (Chapter 11), The Haworth's Food Products Press, New York.

Johansen, L. K., and J. C. Carrington. 2001. Silencing on the spot. Induction and suppression of RNA silencing in the Agrobacterium-mediated transient expression system. Plant Physiol. 126:930-938.

Jones, R. A. C. 1990. Strain group specific and virus specific hypersensitive reaction to infection with potyviruses in potato cultivars. Ann. Appl. Biol. 117:93-105.

Kalderon, D., B. L. Roberts, W. D. Richardson, and A. E. Smith. 1984. A short amino acid sequence able to specify nuclear location. Cell 39:499-509.

Kalland, K. -H, A. M. Szilvay, K. A. Brokstad, W. Sætrevik, and G. Haukenes. 1994. The Human immunodeficiency virus Type 1 Rev protein shuttles between the cytoplasm and nuclear compartments. Mol. Cel. Biol. 14:7436-7444.

Kang, B. C., I. Yeam, and M. M. Jahn. 2005. Genetics of plant virus resistance. Annu. Rev. Phytopathol. 43:581-621. 
Kasschau, K. D., Z. Xie, E. Allen, C. Llave, E. J. Chapman, K. A. Krizan, and J. C. Carrington. 2003. P1/HC-Pro, a viral suppressor of RNA silencing, interferes with Arabidopsis development and miRNA function. Dev. Cell 4:205-217.

Köhm, B. A., M. G. Goulden, J. E. Gilbert, T. A. Kavanagh, and D. C. Baulcombe. 1993. A Potato virus $X$ resistance gene mediates an induced, nonspecific resistance in protoplasts. Plant Cell 5:913-920.

Lakatos, L., G. Szittya, D. Silhavy, and J. Burgyan. 2004. Molecular mechanism of RNA silencing suppression mediated by p19 protein of Tombusviruses. EMBO J. 23:876-884.

Le Romancer, M., C. Kerlan, and M. Nedellec. 1994. Biological characterization of various geographical isolates of Potato virus $Y$ inducing superficial necrosis on potato tubers. P1. Pathol. 43:138-144.

Li, H-. W., and S-. W. Ding. 2005. Antiviral silencing in animals. FEBS letters 579:59655973.

Li, F., and S-. W. Ding. 2006. Virus counterdefense: diverse strategies for evading the RNAsilencing immunity. Annu. Rev. Microbiol. 60:503-531.

Li, H.- W., A. P. Lucy, H. -S. Guo, W. -X. Li, L. -H. Ji, S. -M. Wong, and S. -W. Ding. 1999. Strong host resistance targeted against a viral suppressor of the plant gene silencing defense mechanism. EMBO J.18:2683-2691.

Liu, H. B., M. M. Reavy, S. A. Swanson, and S. A. MacFarlane. 2002. Functional replacement of the Tobacco rattle virus cysteine-rich protein by pathogenicity proteins from unrelated plant viruses. Virology 298:232-239.

Liu, D. H., D. J. Robinson, G. H. Duncan, and B. D. Harrison. 1991. Nuclear location of the 16K non-structural protein of Tobacco rattle virus. J. Gen. Virol. 72:1811-1817.

Llave, C., K. D. Kasschau, and J. C. Carrington. 2000. Virus-encoded suppressor of posttranscriptional gene silencing targets a maintenance step in the silencing pathway. Proc. Natl. Acad. Sci. USA 97:13401-13406.

Lucy, A. P., H. -S. Guo, W. -X. Li, and S. -W. Ding. 2000. Suppression of posttranscriptional gene silencing by a plant viral protein localized in the nucleus. EMBO J. 19:1672-1680. 
MacFarlane, S. A. 1997. Natural recombination among plant virus genomes: evidence from tobraviruses. Semin. Virol. 8:25-31.

MacFarlane, S. A. 1999. Molecular biology of the Tobraviruses. J. Gen. Virol. 80:27992807.

MacFarlane, S. A. 2003. Molecular determinants of the transmission of plant viruses by nematodes. Mol. Plant Pathol. 4:211-215.

Malcuit, I., W. D. Jong, D. C. Baulcombe, D. C. Shields, and T. A. Kavanagh. 2000. Acquisition of multiple virulence/avirulence determinants by Potato virus $X$ has occurred through convergent evolution rather than through recombination. Virus genes 20:165-172.

Malcuit, I., M. R. Marano, T. A. Kavanagh, W. D. Jong, A. Forsyth, and D. C. Baulcombe. 1999. The $25-\mathrm{kDa}$ movement protein of PVX elicits $N b$-mediated hypersensitive cell death in potato. Mol. Plant-microbe Interact. 12:536-543.

Mallory, A. C., B. J. Reinhart, D. Bartel, V. B. Vance, and L. H. Bowman. 2002. A viral suppressor of RNA silencing differentially regulates the accumulation of short interfering RNAs and micro-RNAs in tobacco. Proc. Natl. Acad. Sci. USA 99:15228-15233.

Martin, G. B., A. J. Bogdanove, and G. Sessa. 2003. Understanding the functions of plant disease resistance proteins. Annu. Rev. Plant Biol. 54:23-61.

Martinez, J., and T. Tuschl. 2004. RISC is a 5' phosphomonoester-producing RNA endonuclease. Genes and Dev. 18:975-980.

Meister, G., and T. Tuschl. 2004. Mechanisms of gene silencing by double-stranded RNA. Nature 431:343-349.

Mérai, Z., Z. Kerényi, S. Kertész, M. Magna, L. Lakatos, and D. Silhavy. 2006. Doublestranded RNA binding may be a general plant RNA viral strategy to suppress RNA silencing. J. Virol. 80:5747-5756.

Mestre, P., G. Brigneti, and D. C. Baulcombe. 2000. An Ry-mediated resistance response in potato requires the intact active site of the NIa proteinase from Potato virus $Y$. Plant $\mathrm{J}$. 23:1-11.

Meyer, B. E., and M. H. Malim. 1994. The HIV-1 Rev trans-activator shuttles between the nucleus and the cytoplasm. Genes Dev. 18:1538-1547.

Mills, W. R. 1965. Inheritance of immunity to Potato virus X. Am. Potato J. 42:294-295. 
Mlotshwa, S., O. Voinnet, M. F. Mette, M. Matzke, H. Vaucheret, S. -W. Ding, G. Pruss, and V. B. Vance. 2002. RNA silencing and mobile silencing signal. Plant Cell [suppl.]:289-301.

Moissiard, G., and O. Voinnet. 2004. Viral suppression of RNA silencing in plants. Mol. Pl. Pathol. 5:71-82.

Mojtahedi, H., J. M. Crosslin, G. S. Santo, C. R. Brown, and P. E. Thomas. 2001. Pathogenicity of Washington and Oregon isolates of Tobacco rattle virus on potato. Am. J. Potato Res. 78:183-190.

Nakayashiki, H. 2005. RNA silencing in fungi: Mechanisms and applications. FEBS letters 579:5950-5957.

Nimchuk, Z., T. Eulgem, B. F. Holt III, and J. L. Dangl. 2003. Recognition and response in the plant immune system. Annu. Rev. Genet. 37:579-609.

Palauqui, J. C., T. Elmayan, J. M. Pollien, and H. Vaucheret. 1997. Systemic acquired silencing: transgene-specific post-transcriptional silencing is transmitted by grafting from silenced stocks to non-silenced scions. EMBO J. 16:4738-4745.

Ploeg, A. T., C. J. Asjes, and D. J. F. Brown. 1991. Tobacco rattle virus serotypes and associated nematode vector species of Trichodoridae in the bulb-growing areas in the Netherland. Neth. J. Plant Pathol. 97:311-319.

Ploeg, A. T., D. J. F. Brown, and D. J. Robinson. 1992a. Acquisition and subsequent transmission of Tobacco rattle virus isolates by Paratrichodorus and Trichodorus nematode species. Neth. J. Plant Path. 98:291-300.

Ploeg, A. T., D. J. F. Brown, and D. J. Robinson. 1992b. The association between species of Trichodorus and Paratrichodorus vector nematodes and serotypes of Tobacco rattle tobravirus. Ann. Appl. Biol. 121:619-630.

Provvidenti, R., and R. O. Hampton. 1992. Sources of resistance to viruses in the Potyviridae. Arch. Virol. suppl. 5:189-211.

Qu, F., T. Ren, and T. J. Morris. 2003. The coat protein of Turnip crinkle virus suppresses post-transcriptional gene silencing at an early initiation step. J. Virol. 77:511-522.

Querci, M., R. van der Vlugt, R. Goldbach, and L. F. Salazar. 1993. RNA sequene of Potato virus $X$ strain HB. J. Gen. Virol. 74:2251-2255. 
Reavy, B., S. Dawson, T. Canto, and S. A. MacFarlane. 2004. Heterologous expression of plant virus genes that suppress post-transcriptional gene silencing results in suppression in RNA interference in Drosophila cells. BMC Biotechnol. 4:18.

Ritter, E., T. Debener, A. Barone, F. Salamini, and C. Gebhardt. 1991. RFLP mapping on potato chromosomes of two genes controlling extreme resistance to Potato virus $X$ (PVX). Mol. Gen. Genet. 227:81-85.

Robbins, J., S. M. Dilworth, R. A. Laskey, and C. Dingwall. 1991. Two interdependent basic domains in nucleoplasmin nuclear targeting sequence: identification of a class of bipartite nuclear targeting sequence. Cell 64:615-623.

Robinson, D. J. 1994. Sequences at the ends of RNA-2 of 16, a recombinant tobravirus. Arch. Virol. [suppl.] 9:245-251.

Robinson, D. J. 2004. Identification and nucleotide sequence of a Tobacco rattle virus RNA1 variant that causes spraing disease in potato cv. Bintje. J. Phytopathol. 152:286-290.

Robinson, D. J., M. F. B. Dale, and D. Todd. 2004. Factors affecting the development of disease symptoms in potatoes infected by Tobacco rattle virus. Eur. J. Pl. Pathol. 110:921928.

Robinson, D. J., W. D. O. Hamilton, B. D. Harrison, and D. C. Baulcombe. 1987. Two anomalous tobravirus isolates: evidence for RNA recombination in nature. J. Gen. Virol. 68:2551-2561.

Robinson, D. J., and B. D. Harrison. 1989a. Tobacco rattle virus. CMI/AAB Description of Plant Viruses, no. 346.

Robinson, D. J., and B. D. Harrison. 1989b. Pepper ringspot virus. CMI/AAB Description of Plant Viruses, no. 347.

Ross, H. 1958. Inheritance of extreme resistance to virus Y in Solanum stoloniferum and its hybrids with Solanum tuberosum. Proc. Conf. Potato Virus Dis., 1957, pp. 204-211, LisseWageningen, The Netherland;Veenman.

Ross, H. 1986. Potato breeding-problems and perspectives. In: J. Brandes, R. Bartels, J. Völk, and C. Wetter (eds.). Advances in Plant Breeding. J. Plant Breed. 13 [suppl.]. Pual Parey, Berlin and Humburg, Germany. 
Roth, B. M., G. J. Pruss, and V. B. Vance. 2004. Plant viral suppressors of RNA silencing. Virus Res. 102:97-108.

Sandgren, M., R. L. Plaisted, K. N. Watanabe, S. Olsson, and J. P. T. Valkonen. 2002. Evaluation of some North and South American potato breeding lines for resistance to Potato mop-top virus in Sweden. Am. J. Potato Res. 79:205-210.

Santa-Cruz, S., and D. C. Baulcombe. 1993. Molecular analysis of Potato virus $X$ isolates in relation to the potato hypersensitivity gene $N x$. Mol. Plant-Microbe Interact. 6:707-714.

Silhavy, D., A. Molnár, A. Lucioli, G. Szittya, C. Hornyik, M. Tavazza, and J. Burgyán. 2002. A viral protein suppresses RNA silencing and binds silencing-generated, 21-to 25nucleotide double-stranded RNAs. EMBO J. 21:3070-3080.

Siomi, H., and G. Dreyfuss. 1995. A nuclear localization domain in the hnRNP A1 protein. J. Cell Biol. 129:551-560.

Solomon R. M. 1985. The relationship of genes $X i$ and $N b$ for resistance to Potato virus $X$. Heredity 55:135-138.

Solomon-Blackburn, R. M., and H. Barker. 2001a. A review of host major-gene resistance to Potato viruses $X, Y, A$, and $V$ in potato: genes, genetics and mapped locations. Heredity 86:8-16.

Solomon-Blackburn, R. M., and H. Barker. 2001b. Breeding virus resistance potatoes (Solanum tuberosum): a review of traditional and molecular approaches. Heredity 86:17-35.

Soosaar, J. L. M., T. M. Burch-Smith, and S. P. Dinesh-Kumar. 2005. Mechanisms of plant resistance to viruses. Nature Rev. 3:789-798.

Syller, J. 2003. Inhibited long-distance movement of Potato leafroll virus to tubers in potato genotypes expressing combined resistance to infection, virus multiplication and accumulation. J. Phytopathol. 151:492-499.

Taylor, C. E., and D. J. F. Brown. 1997. Nematode Vectors of Plant Viruses, 286 pp., Wallingford, England, CABI.

Tommiska, T. J., J. H. Hämäläinen, K. N. Watanabe, and J. P. T. Valkonen. 1998. Mapping of the gene $N x_{p h u}$ that controls hypersensitive resistance to Potato virus $X$ in Solanum phureja IvP35. Theor. Appl. Genet. 96:840-843. 
Vaistij, F. E., L. Jones, and D. C. Baulcombe. 2002. Spreading of RNA targeting and DNA methylation in RNA silencing requires transcription of the target gene and a putative RNAdependent RNA polymerase. Plant Cell 14:857-867.

Valkonen, J. P. T. 1994. Natural genes and mechanisms for resistance to viruses in cultivated and wild potato species (Solanum spp.). Pl. Breeding 112:1-16.

Valkonen, J. P. T., R. A. C. Jones, S. A. Slack, and K. N. Watanabe. 1996. Resistance specificities to viruses in potato: standardization of nomenclature. Pl. Breeding 115:433438.

Van Hoof, H. A. 1968. Transmission of Tobacco rattle virus by Trichodorus species. Nematologica 14:20-24.

Van Wezel, R., X. Dong, H. Liu, P. Tien, J. Stanley, and Y. Hong. 2002. Mutation of three cysteine residues in Tomato yellow leaf curl virus-China C2 protein causes dysfunction in pathogenesis and posttranscriptional gene silencing suppression. Mol. Plant-Microbe Interact. 15:203-208.

van Wezel, R., H. Liu, Z. Wu, J. Stanley, and Y. Hong. 2003. Contribution of the zinc finger to zinc and DNA binding by a suppressor of posttranscriptional gene silencing. J. Virol. 77:696-700.

Vance, V., and H. Vaucheret. 2001. RNA silencing in plants-defense and counterdefense. Science 292:2277-2280.

Vassilakos, N., E. K. Vellios, E. C. Brown, D. J. F. Brown, and S. A. MacFarlane. 2001. Tobravirus $2 \mathrm{~b}$ protein acts in trans to facilitate transmission by nematodes. Virology 279:478-487.

Vaucheret, H., C. Béclin, T. Elmayan, F. Feuerbach, C. Godon, J-. P. Morel, P. Mourrian, J-. C. palauqui, and S. Vernhettes. 1998. Transgene-induced gene silencing in plants. Plant J. 16:651-659.

Vellios, E., D. J. F. Brown, and S. A. MacFarlane. 2002. Substitution of a single amino acid in the $2 \mathrm{~b}$ protein of Pea early-browning virus affects nematode transmission. J. Gen. Virol. 83:1771-1775.

Vidal, S., H. Cabrera, R. A. Andersson, A. Fredriksson, and J. Valkonen. 2002. Potato gene $Y-1$ is an $N$ gene homology that confers cell death upon infection with Potato virus $Y$. Mol. Plant-Microbe Interact. 15:717-727. 
Visser, P. B., A. Mathis, and H. J. M. Linthorst. 1999. Tobraviruses. Encyclopaedia of Virology. In: A. A. Granoff and R. G. Webster (Eds.), London, Academic Press 2nd edn., pp. 1784-1789.

Voinnet, O. 2001. RNA silencing as a plant immune system against viruses. Trends Genet. 17:449-459.

Voinnet, O. 2005. Induction and suppression of RNA silencing: insights from viral infection. Nature Rev. 6:206-220.

Voinnet, O., and D. C. Baulcombe. 1997. Systemic signaling in gene silencing. Nature 389:553.

Voinnet, O., C. Lederer, and D. C. Baulcombe. 2000. A viral movement protein prevents spread of the gene silencing signal in Nicotiana benthamiana. Cell 103:157-167.

Voinnet, O., Y. M. Pinto, and D. C. Baulcombe. 1999. Suppression of gene silencing: A general strategy used by diverse DNA and RNA viruses of plants. Proc. Natl. Acad. Sci. USA 96:14147-14152.

Whitham, S. A., S. P. Dinesh-Kumar, D. Choi, R. Hehl, C. Corr, and B. Baker. 1994. The product of the Tobacco mosaic virus resistance gene $N$ : similarity to Toll and the interleukin-1 receptor. Cell 78:1101-1115.

Xenophontos, S., D. J. Robinson, M. F. B. Dale, and D. J. F. Brown. 1998. Evidence for persistent, symptomless infection of some potato cultivars with Tobacco rattle virus. Potato Res. 41:255-265.

Yelina, N. E., T. N. Erokhina, N. I. Lukhovitskaya, E. A. Minina, M. V. Schepetilnikov, D. E. Lesemann, J. Schiemann, A. G. Solovyev, and S. Y. Morozov. 2005. Localization of Poa semilatent virus cysteine-rich protein in peroxisomes is dispensable for its ability to suppress RNA silencing. J. Gen. Virol. 86:479-489.

Zamore, P. D., T. Tuschl, P. A. Sharp, and D. P. Bartel. 2000. RNAi: double-stranded RNA directs the ATP-dependent cleavage of mRNA at 21 to 23 nucleotides intervals. Cell 101:25-33.

Ziegler-Graff, V., P. J. Guilford, and D. C. Baulcombe. 1991. Tobacco rattle virus RNA-1 $29 \mathrm{~K}$ gene product potentiates viral movement and also affects symptom induction in tobacco. Virology 182:145-155. 


\title{
CHAPTER 2
}

\section{Tobacco rattle virus $29 \mathrm{~K}$ movement protein is the elicitor of extreme and hypersensitive-like resistance in two cultivars of Solanum tuberosum*}

\author{
Walid Ghazala and Mark Varrelmann ${ }^{\dagger}$ \\ University of Göttingen, Department of Crop Sciences, Section Plant Virology, , \\ Grisebachstr. 6, 37077 Göttingen, Germany
}

${ }^{\dagger}$ Both authors contributed equally to this work

\begin{abstract}
Leaf infection experiments were used to analyze the host responses of Solanum tuberosum cultivars, known to be resistant or susceptible to natural, nematode-mediated infection of tubers and necrosis induction ("spraing") by tobacco rattle virus isolate PpK20 (TRVPpK20). Extreme and hypersensitive-like resistance (ER and HR-like), as well as spreading veinal necrosis and systemic infection were observed. Agroinfection of leaves with a DsRed expressing TRV cDNA clone revealed ER to function on the single-cell level, inhibiting virus replication and possessing the potential to initiate a cell death response. HR-like necrosis was characterized by initial virus replication and cell-to-cell movement, before the onset of necrosis. Transient agroexpression and potato virus X (PVX)-mediated expression assays demonstrated that the $29 \mathrm{~K}-\mathrm{PpK} 20$ movement protein (MP) can elicit ER and HR-like celldeath. A TRV isolate, PpO85M, known to overcome the resistance to spraing in plants that are resistant to TRV-PpK20 encoded a variant $29 \mathrm{~K}$ protein which did not elicit HR in PpK20HR plants. Our results show that the TRV MP is the elicitor of both ER and HR-like celldeath, that no other TRV encoded proteins or RNA replication are required for its elicitor activity and that the host reactions are likely to be controlled by single dominant resistance genes.
\end{abstract}

Additional keywords: avirulence gene, gene-for-gene, resistance-breaking, Tobravirus

* This paper is accepted for publication in Molecular Plant-Microbe Interactions. 


\section{INTRODUCTION}

Tobacco rattle virus (TRV), genus Tobravirus, is able to infect a broad range of plant species, possesses worldwide distribution and naturally infects a very large number of plant species (Harrison and Robinson 1978). The virus consists of two RNA species. Genome organization, expression strategy, and variability of strains are summarized by MacFarlane (1999). RNA-1, highly conserved between different isolates, encodes four non-structural proteins, 134-kDa methyltransferase-helicase and 194-kDa RNA-dependent RNA polymerase (read-through of the 134-kDa ORF) both of which are believed to be involved in virus replication (Hamilton and Baulcombe 1989). The 29-kDa size protein (29K), translated from a subgenomic (sg) RNA, represents the viral movement protein (MP), which is also involved in virus accumulation in Nicotiana tabacum (Ziegler-Graff et al. 1991). The RNA-1 3'proximal encoded $16-\mathrm{kDa}$ cysteine-rich protein $(16 \mathrm{~K})$ functions as a pathogenicity factor and suppressor of RNA silencing (Liu et al. 2002a; Reavy et al. 2004; Ghazala et al. unpublished data). RNA-2, possessing higher variability between isolates than RNA-1 encodes the coat protein (CP) and in some isolates, other non-structural proteins responsible for vector transmission by plant parasitic nematodes in the genera Trichodorus and Paratrichodorus (trichodorids) (Hernández et al. 1997; MacFarlane et al. 1995, 1996; Ploeg et al. 1993). TRV can cause two types of infection: a multiplying infection (M-type) in which both RNAs are present and the virus produces nucleoprotein particles (Cadman and Harrison 1959), and a non-multiplying infection (NM-type) where only uncapsidated RNA-1 is present and the virus spreads in the complete absence of RNA-2 (MacFarlane 1999).

TRV can induce a disease called "spraing" in potato tubers, which has significant economic implications. Tuber spraing is induced when TRV is transmitted by nematodes to potato roots or tubers (Cadman 1959; Eibner 1959; Walkinshaw and Larson 1959; summarized in Robinson 2004) and can be characterized by arcs and/or flecks of brown corky tissue present in the tuber flesh or on the surface of infected tubers. These tuber defects may render the tubers unsaleable even at relatively low levels of symptom expression. Chemical control of soil-borne vector nematodes is difficult (Harrison and Robinson 1978), does not allow for specific targeting and is therefore prohibited in most countries. Virus testing is not reliable since antisera against CP do not recognize NM-type isolates (Harrison and Robinson 1978). Therefore, in addition to certification schemes in seed potato production and diagnosis based on viral nucleic acid detection, natural virus resistance is the only 
available and probably the most satisfactory measure for TRV control in the field (SolomonBlackburn and Barker 2001b; Valkonen 1994).

Barker and Dale (2006) reported that resistance to TRV appears to be controlled by a single resistance gene in some potato genotypes. Resistance assessment in naturally infected soils or in the greenhouse in pots with tested soil inhabiting viruliferous trichodorid nematodes by scoring of tuber symptoms have been described (Dale and Solomon 1988). However, such resistance assessment suffers significantly from the drawback of uneven vector distribution and uneven weather conditions in field trials. It is generally believed that spraing represents a hypersensitive resistance reaction (HR). This is because only few plants derived from spraing-affected tubers develop systemic "stem mottle" symptoms (Harrison 1968) and it is difficult to isolate TRV from necrotic tuber tissues (Xenophontos et al. 1998). Although experimental evidence for this idea is lacking, it is notable that susceptible cultivars undergoing compatible interactions with TRV exhibit few if any spraing symptoms in the tuber flesh (Dale et al. 2000; Xenophontos et al. 1998). However, clones or cultivars exist that are thought to react with extreme resistance to attempted infection of tubers with TRV since it is impossible to subsequently re-isolate TRV from them (Robinson and Dale 1994). Cultivar Russet Burbank, for example, exhibits spraing in response to nematode-mediated infection with TRV (Mojtahedi et al. 2001). In contrast, cv. Bintje is generally considered to be resistant to infection (Harrison 1968; Mojtahedi et al. 2001; Xenophontos et al. 1998). Engsbro (1973) suggested that resistance in cv. Bintje is a kind of hypersensitivity, limiting nematode-borne TRV to a few cells at the inoculation site. In addition, cv. Saturna is described as TRV-resistant by an unknown mechanism (Barker and Dale 2006; Robinson 2004; Robinson and Dale 1994). However, the experimental proof is missing as to whether spraing represents a hypersensitive host reaction and whether resistance to TRV infection fits into the classical categories of incompatible host resistance response in potato to virus infection. Recently a mild RNA-1 variant of a TRV M-type isolate (TRV PpO85M) from the Netherlands, was found to induce symptoms of spraing disease, when naturally transmitted, in tubers of two out of five resistant cultivars tested, including cv. Bintje but not in that of cv. Saturna (Robinson 2004).

According to Cooper and Jones (1983), Valkonen (1994), Valkonen et al. (1996), Solomon-Blackburn and Barker (2001a), Hull (2002) and Kang et al. (2005), host responses to virus in plants, including potato, can be categorized in different reactions. A non-host plant cannot be infected and displays immunity. Infectible hosts may display ER and/or HR or 
susceptibility, including susceptibility to systemic virus movement. Susceptible plants may show severe disease or they may be tolerant and undergo a latent, symptomless infection. In all cases of ER and HR in potato to virus infection described so far, the resistance is monogenic based on dominant $R$-genes (Kang et al. 2005; Solomon-Blackburn and Barker 2001a). In order to activate $R$-gene-mediated defense response, which confines the virus to the point of entry, or at least inhibits the spread of the virus throughout the plant, the invading virus needs to encode a matching avirulence ( $a v r$ ) gene, encoding an elicitor (HammondKosack and Jones 1996; Nimchuk et al. 2003). Several such plant virus genes possessing elicitor functions have been described (Culver 1997; Hull 2002).

However, gaining clear experimental evidence for different resistance reactions in potato against TRV infection is still a challenge. Moreover, it is not known whether the resistance reaction of potato tubers to nematode-mediated infection correlates with resistance to mechanical leaf infection. To characterize these complex TRV-host interactions, we used potato cultivars that show tuber spraing (Mojtahedi et al. 2001), ER and HR (Robinson 2004) in response to nematode-mediated TRV infection in order to investigate the host response to mechanical leaf-inoculation with the TRV isolate PpK20. We detected different host reactions fitting nicely into the categories of "Spreading necrosis", ER and HR, suggesting that spraing and resistance to spraing is not determined by the mode of inoculation, vectored or artificial. This prompted us to identify the viral avr-gene for ER and HR. We were able to show that the RNA-1 encoded 29K MP is responsible for the elicitation of both types of resistance in potato.

\section{RESULTS}

\section{Mechanical and Agrobacterium-mediated leaf inoculation of potato with TRV-PpK20 reveals three classical host reaction types.}

Potato cvs. Russet Burbank, Bintje and Saturna were tested for their host reaction to mechanical leaf infection with a DsRed-tagged derivative of TRV isolate PpK20 (TRVDsRed).. TRV PpK20 cDNA clones of RNA-1 (pTRV1) and RNA-2 expressing the DsRed fluorescent marker protein (pTRV2-DsRed) instead of 2b and 2c ORFs were agroinoculated and propagated in N. benthamiana plants. Leaf sap was used for mechanical inoculation of potato cultivars and $N$. benthamiana. Host responses were monitored at 3, 5 and 7 dpi (Fig. 1A, host response shown at 7 dpi). Leaves of cv. Russet Burbank displayed cell-death in 
response to TRV inoculation, but the necrotic lesions enlarged and surrounding leaf tissue displayed yellowing. The spreading necrosis reached the main leaf vein at $7 \mathrm{dpi}$. The inoculated leaf died a few days after the virus had reached the veins and the infection progressed into non-inoculated tissue. Epifluorescence microscopy (FM) examinations revealed RNA-2 encoded DsRed fluorescence in the tissue surrounding the necrotic leaf area (Fig. 1B), and in upper non-inoculated leaves at 30 dpi (data not shown). TRV RNA-1 was detectable in both inoculated and in non-inoculated leaves using RT-PCR amplification of the 29K gene (Fig. 2 and RNA-2 data not shown). This finding suggests a hypersensitive-like host reaction without the ability to limit the virus spread. The systemically infected leaves of cv. Russet Burbank, however, displayed no necrosis but only slight mosaic (data not shown). Interestingly, inoculated "Bintje" leaves displayed necrotic lesions, but these lesions did not enlarge (Fig. 1A, host response shown at 7 dpi). Replication of RNA-2 was not detected via FM monitoring of DsRed expression outside the necrotic lesions (Fig. 1B). RNA-1 was detected via RT-PCR amplification reproducible only up to 5 dpi in inoculated leaves but never in non-inoculated tissue (Fig. 2). Therefore, the resistance reaction observed was classified as HR-like necrosis. In contrast, leaves of cv. Saturna did not show any host reaction, nor was TRV infection detected in the inoculated tissue using RT-PCR and FM analysis. This non-host reaction gave a first indication for the existence of ER in cv. Saturna.

Subsequently, leaf-agroinfection of TRV-DsRed (pTRV1 + pTRV2-DsRed) was carried out to confirm the HR-like and spreading necrosis observed using mechanical inoculation. "Saturna" plants reacting with ER were tested to see whether constitutive expression of viral RNAs could induce a host reaction and whether virus replication (via RNA-2 encoded DsRed detection) would occur at all. To exclude the possibility of interference with the host resistance reaction by Agrobacterium tumefaciens, bacteria harboring an empty binary plant expression plasmid (pBIN61S) were infiltrated at different densities $\left(8 \times 10^{6}\right.$ cells $/ \mathrm{ml}\left[\mathrm{OD}_{600}=1\right]$ to $1.6 \times 10^{4}$ cells $/ \mathrm{ml}$ in steps of dilution factor 2$)$. An $A$. tumefaciens suspension with a density of $3.2 \times 10^{4}$ cells $/ \mathrm{ml}$ (corresponding to 250 -fold dilution of $\mathrm{OD}_{600}=1$ ) induced no visible host reaction within $10 \mathrm{dpi}$ and was used for all subsequent infiltrations (data not shown). Additionally 35S-DsRed was transiently agroexpressed in leaf 
(A)
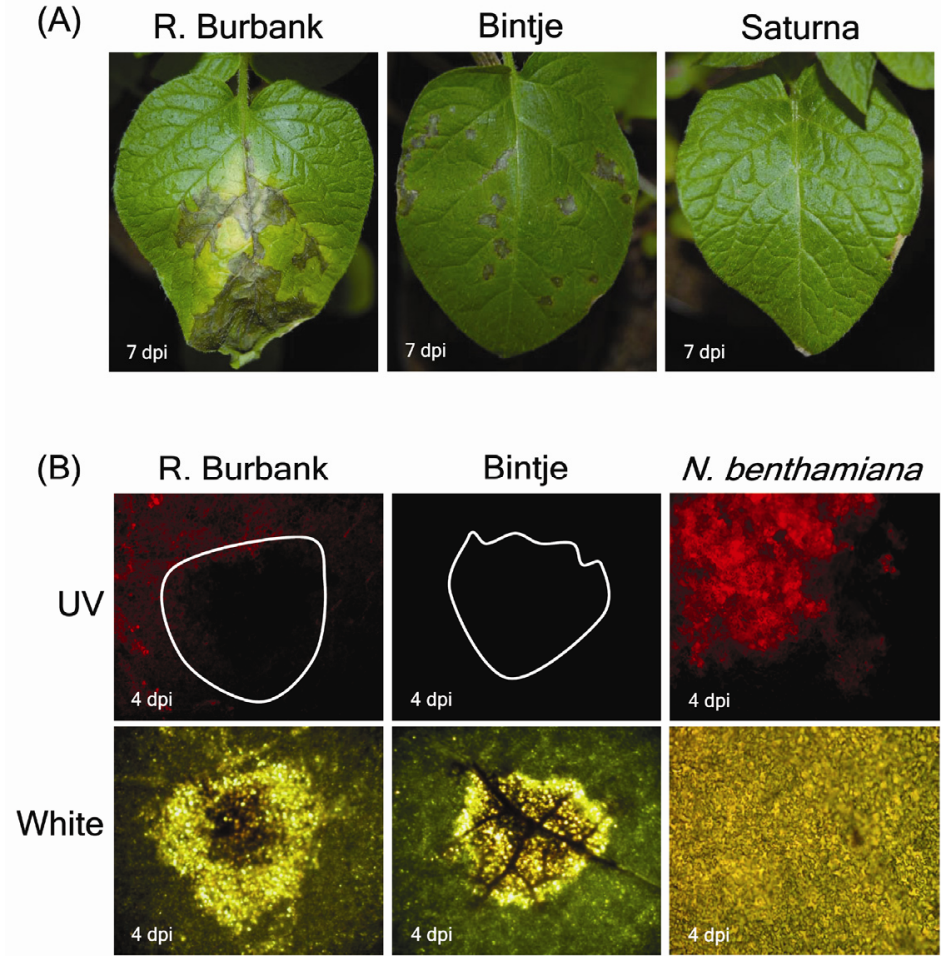

Fig. 1. Mechanical inoculation of "Russet Burbank", "Bintje" and "Saturna" leaves with TRV-DsRed (isolate PpK20) infected N. benthamiana leaf-sap. A, Host response at 7 dpi. B, White light microscopy photos and FM DsRed-analysis of "Russet Burbank" and "Bintje" leaf tissue respectively at $25 \mathrm{x}$ magnification in comparison with inoculated $N$. benthamiana leaf tissue at $100 \mathrm{x}$ magnification. White drawing-lines indicate the border of the dying and already necrotic leaf area shown in corresponding white-light microscopy photos. "Russet Burbank" leaves display necrosis (white light) unable to limit the virus movement as indicated by the TRV encoded DsRed expression outside the developing necrotic area (UV light). "Bintje" leaves show HR-like cell death and no virus spread outside the necrotic area, respectively.

tissue of all three cultivars and DsRed expression was detectable even at 10 dpi, verifying the survival of agroinfiltrated tissue (data not shown). The host reaction and TRV-DsRed spread observed in cvs. Russet Burbank and Bintje following agroinfection was identical to that observed following mechanical infection (Fig. 3A). Analysis of infiltrated "Bintje" leaf tissue at 4 dpi revealed DsRed fluorescence in several cells, indicating initial TRV replication before cell death occurred (Fig. 3B). In contrast, no DsRed-expression could be observed at any time after TRV-DsRed agroinfiltration in "Saturna" leaves. The infiltrated leaf tissue displayed necrosis and cell death at 7 dpi (Fig. 3A). This demonstrated that in "Saturna" constitutive expression of both viral RNAs in a multitude of leaf cells induced HR-like tissue necrosis in addition to the ER reaction. 

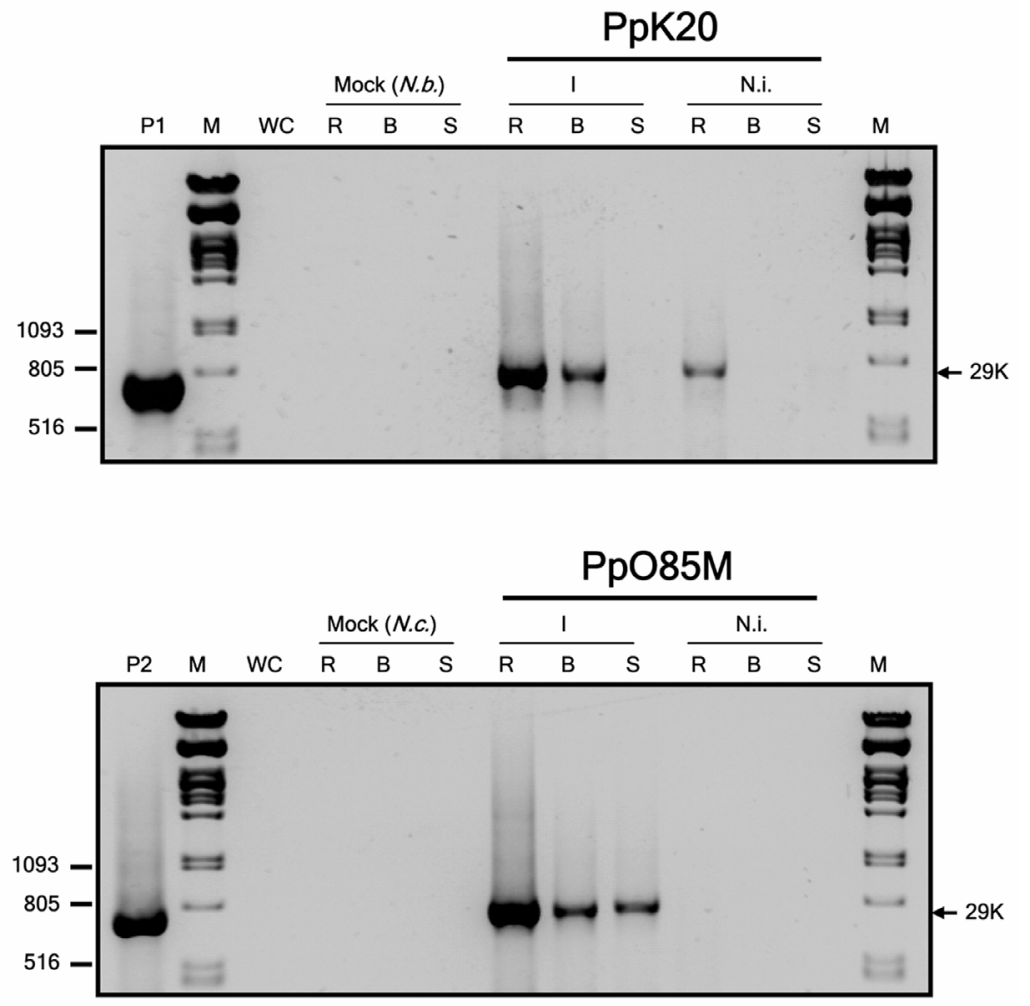

Fig. 2. RT-PCR detection of RNA-1 in mechanically inoculated leaves at 4 dpi (I) and non-inoculated leaves at 30 dpi (N.i.) of potato cvs. Russet Burbank (R), Bintje (B), and Saturna (S) with TRV isolate PpK20 (upper panel) and PpO85M (lower panel) using 29K ORF specific primers. Total RNA from systemic PpK20-infected N. benthamiana (P1) and PpO85M-infected N. clevelandii leaves (P2) were used as positive controls. N.b. and N.c. are RNA samples from non-inoculated N. benthamiana and N. clevelandii leaves respectively. WC: water control. The expected position for $29 \mathrm{~K}$ amplification product $(756 \mathrm{bp}$ ) is indicated..

tissue of all three cultivars and DsRed expression was detectable even at $10 \mathrm{dpi}$, verifying the survival of agroinfiltrated tissue (data not shown). The host reaction and TRVDsRed spread observed in cvs. Russet Burbank and Bintje following agroinfection was identical to that observed following mechanical infection (Fig. 3A). Analysis of infiltrated "Bintje" leaf tissue at 4 dpi revealed DsRed fluorescence in several cells, indicating initial TRV replication before cell death occurred (Fig. 3B). In contrast, no DsRed-expression could be observed at any time after TRV-DsRed agroinfiltration in "Saturna" leaves. The infiltrated leaf tissue displayed necrosis and cell death at 7 dpi (Fig. 3A). This demonstrated that in "Saturna" constitutive expression of both viral RNAs in a multitude of leaf cells induced HRlike tissue necrosis in addition to the ER reaction. 


\section{K-PpK20 is the elicitor of ER- and HR-mediated TRV resistance in potato.}

The results described above led to the hypothesis that the resistance is inherited monogenically and therefore one viral gene should represent the elicitor of these two newly identified resistance responses to mechanical TRV infection in "Bintje" and "Saturna". In order to allocate the elicitor gene to one of the two TRV genome segments, we repeated the agroinfection only with pTRV1 and observed similar host reaction in all three cultivars (data not shown). Thus, the number of possible candidates could be reduced to the four RNA-1 encoded genes. Initially TRV RNA-1 with a deleted silencing suppressor gene (pTRV1$\Delta 16 \mathrm{~K})$ was produced and used for agroinfection. From the work of Liu et al. (2002a) it was known that without the silencing suppressor protein, GFP expressing TRV replicates poorly and is unable to produce infection foci visible under UV-illumination in N. tabacum plants. However, it was anticipated that the virus helicase and polymerase proteins were translated and that initial replication and the production of subgenomic 29K RNA started before RNA silencing shuts off, or at least down-regulates the replication. Initially pTRV1- $\Delta 16 \mathrm{~K}$ was used together with pTRV2-DsRed (TRV- $\Delta 16 \mathrm{~K}-\mathrm{DsRed}$ ) for agroinfection of 4-week old $N$. benthamiana in direct comparison with TRV-DsRed. DsRed-fluorescence was observed in FM (Fig. 3B). As expected, the deletion of $16 \mathrm{~K}$ led to retarded movement and DsRed fluorescence could be detected in only a few connected cells until 5 dpi. Strong decrease of fluorescence was monitored at 7-9 dpi, suggesting that RNA silencing down-regulates virus replication (data not shown). As expected, leaf infiltration with TRV- $\Delta 16 \mathrm{~K}-\mathrm{DsRed}$ did not induce strong necrotic host reaction compared to infection with wild-type RNA-1 in cv. Russet Burbank. Only single weakly red fluorescing cells were detectable in the agroinfiltrated leaf tissue at 4 dpi (Fig. 3B), demonstrating virus replication (RNA-1 and -2). In contrast, TRV- $\Delta 16 \mathrm{~K}-\mathrm{DsRed}$ agroinfection in "Saturna" and "Bintje" respectively both resulted in hypersensitive host response leading to dead necrotic tissue clearly visible at $7 \mathrm{dpi}$ (Fig. 3A). DsRed fluorescence, however, was seen only in "Bintje" leaf tissue at 4 dpi (before cell death occurred), but not in "Saturna" (Fig. 3B), giving another indication for the ER resistance hypothesis. As a control, single agroinfiltration with pTRV2-DsRed alone did not show any fluorescence, indicating that 35S-transcripts of RNA-2 are not translated in detectable quantities of DsRed without the presence of RNA-1 (data not shown).

Subsequently pTRV1- $\Delta 29 \mathrm{~K}$ was generated and used for agroinfection together with pTRV2-DsRed (TRV- $\Delta 29$ K-DsRed) initially in N. benthamiana. Fluorescence of only single cells, produced by RNA-2 encoded DsRed expression (Fig. 3B) and the lack of viral spread 
suggested that the movement function was strongly reduced if not completely inhibited. In leaves of all three cultivars, viral replication was detected within 5 dpi but restricted to several single cells in the infiltrated patch (Fig. 3B). The $29 \mathrm{~K}$ deletion allowed the virus to replicate even in cells of cv. Saturna. The non-occurrence of necrotic host response in each cultivar tested gave strong evidence for $29 \mathrm{~K}$ elicitor function in both resistant cultivars (Fig.3A), but the possibility that other viral factors are necessary for the $29 \mathrm{~K}$ elicitor function could not be excluded.

Therefore, two additional experimental approaches were used to demonstrate that the movement protein of TRV PpK20, without the presence of other TRV encoded proteins and in absence of virus replication, represents the elicitor in potato cvs. Bintje and Saturna. First, agroinfiltration was used for 35S-driven expression of the single $29 \mathrm{~K}$ ORF in potato leaf tissue. For this purpose the PpK20 29K ORF was PCR amplified, cloned in pBIN61S under control of cauliflower mosaic virus $35 \mathrm{~S}$ promoter $(35 \mathrm{~S}-29 \mathrm{~K})$ and used in a transient agroexpression assay to test its ability to induce HR-like cell death or ER. As control constructs, 35S-empty and $35 \mathrm{~S}-16 \mathrm{~K}$ were used. As expected from the deletion mutants analysis, leaf tissue necrosis was observed in "Bintje" and "Saturna" leaves but not in "Russet Burbank" leaves at 5 dpi only when 35S-29K was infiltrated, while no necrosis could be observed with either $35 \mathrm{~S}$-empty or $35 \mathrm{~S}-16 \mathrm{~K}$ in any of the three cultivars used (Fig. 4A). A non-translatable $29 \mathrm{~K}$ gene (35S-29K-ntr), which did not induce necrosis in any of the tested cultivars by means of agroexpression (Fig. 4A), was used to show that $29 \mathrm{~K}$ protein - not the mRNA - is necessary for this function. RT-PCR detection of 29K-ntr in total nucleic acid extracts from agroinfiltrated leaf patches, pre-treated with DNase I, was carried out to prove that transcripts were produced (data not shown).

Subsequently, plant viral expression vector based on Potato virus $X$ (PVX) was used to express 29K-PpK20. To test susceptibility of all three cultivars to PVX, PVX expressing DsRed (pPVX201-optRed, kindly supplied by E. Maiss) was propagated in N. benthamiana plants and infected leaf sap was mechanically inoculated to potato leaves. At $10 \mathrm{dpi}$, the inoculated leaf was removed and examined for DsRed expression using FM. In all three cultivars, strong DsRed fluorescence could be detected and no resistance host reaction was observed indicating infection with PVX (data not shown). Subsequently, 35S-PVX in binary vector (pGr106, kindly supplied by D. Baulcombe) was used for the generation of 35S-PVX$29 \mathrm{~K}$ and used for agroinoculation of potato cultivars. At 5 dpi HR-like necrosis was observed 


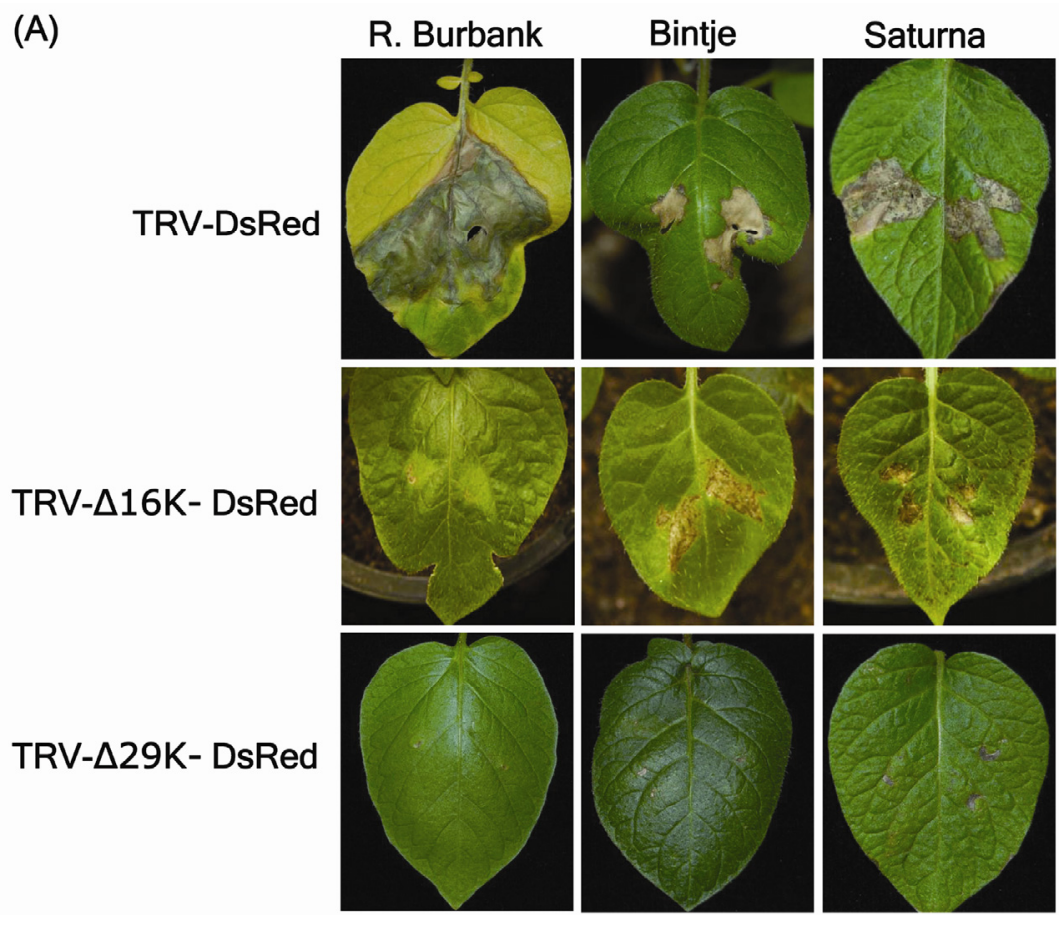

(B)

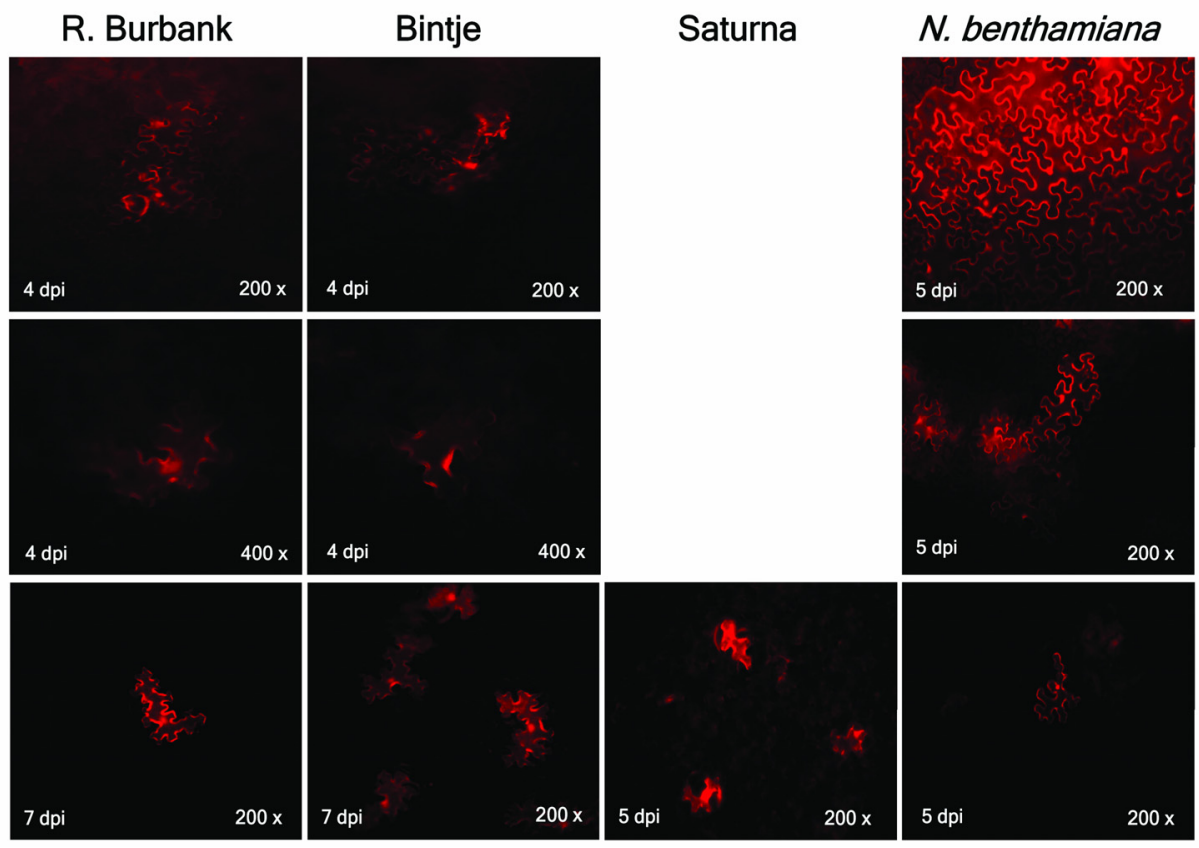

Fig. 3. Leaf-agroinfection of potato cvs. Russet Burbank, Bintje and Saturna. A, Host response of leaf tissue (7 dpi) agroinfected with TRV-DsRed, $-\Delta 16 \mathrm{~K}-D s R e d$, and $-\Delta 29 \mathrm{~K}-D s R e d . \quad$ B, Corresponding photos of FM DsRed analysis in comparison to agroinfiltrated leaves of $N$. benthamiana. A. tumefaciens cultures were infiltrated at cell density of $3.2 \times 10^{4}$ cells $/ \mathrm{ml}$. 
in the infiltrated leaves of both cvs. Bintje and Saturna, but not in cv. Russet Burbank (Fig. 4B), showing that HR-like necrosis is elicited by TRV 29K-PpK20 expressed from another potato infecting virus. PVX-replication (35S-PVX and 35S-PVX-29K) was proven by immunodetection of PVX encoded CP in "Russet Burbank" leaves (Supplementary Figure 1).

(A)

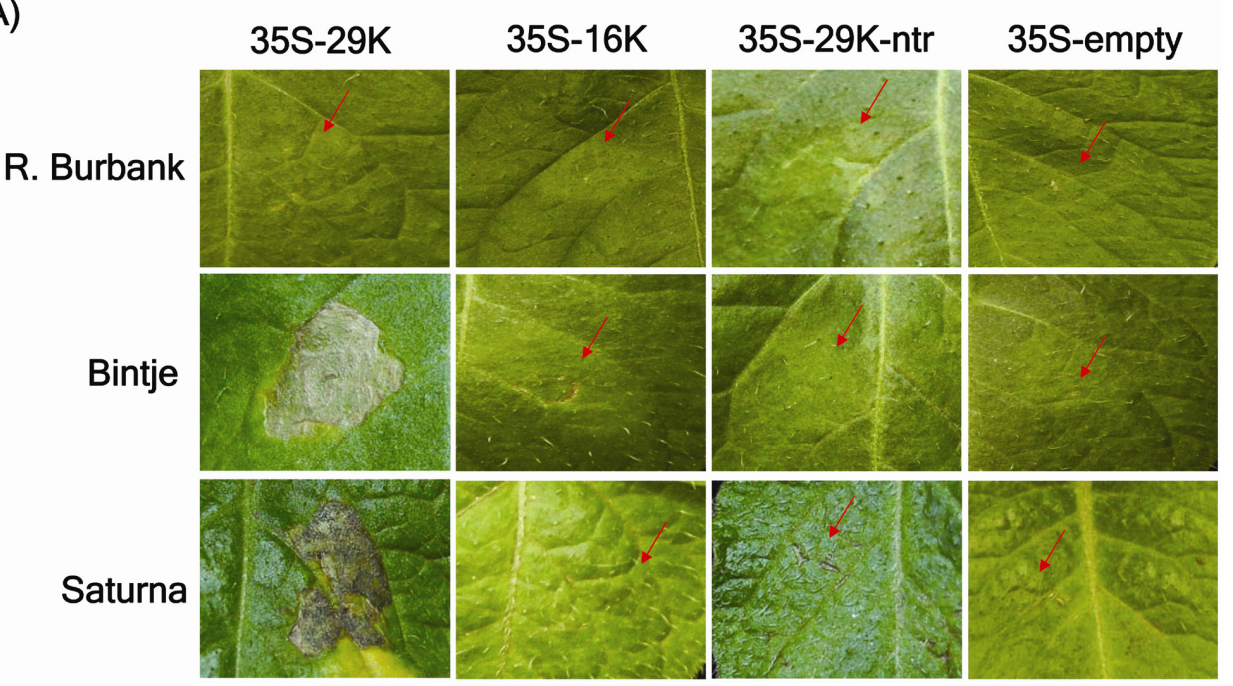

(B)

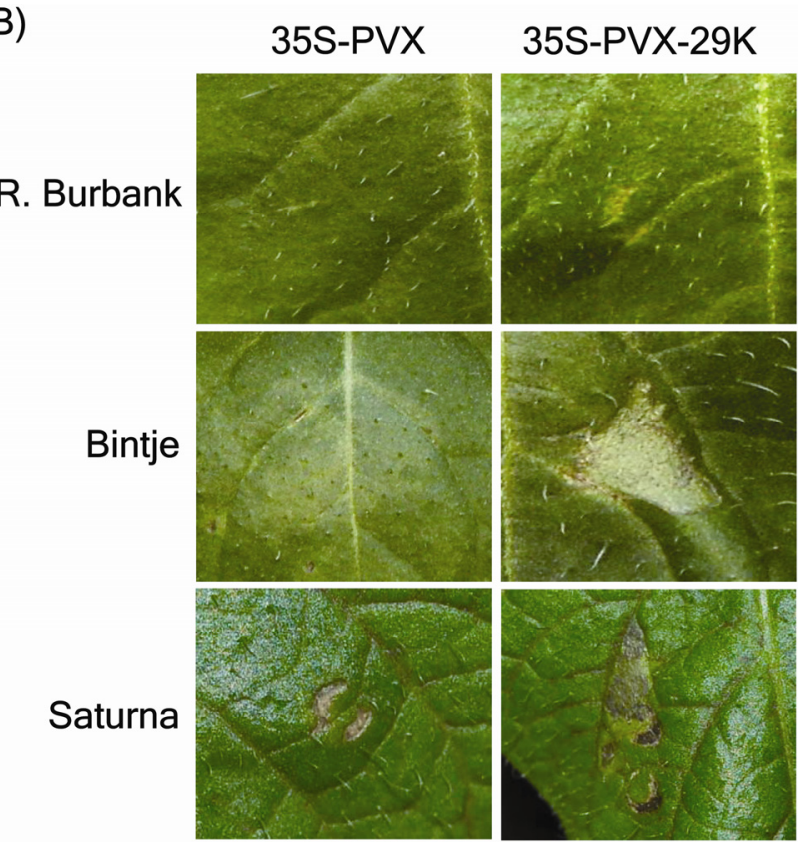

Fig. 4. TRV-PpK20 29K elicits HR and ER resistance response without other TRV encoded proteins or replication. Leaf sections of potato cvs. Russet Burbank, Bintje and Saturna infiltrated with A. tumefaciens $\left(3.2 \times 10^{4}\right.$ cells $\left./ \mathrm{ml}\right)$ transiently expressing A, 35S-29K, 35S-16K, 35S-29K-ntr or 35Sempty control; B, PVX-29K (pGr106-29K) or pPVX (pGr106). Photographs in A and B were taken at 7 dpi. 


\section{Mechanical inoculation of TRV isolate PpO85M induces cell-death in cv. Saturna.}

Recently, Robinson (2004) reported the occurrence of a TRV isolate (PpO85M) which was able to overcome the spraing resistance in "Bintje" but not in "Saturna" by means of nematode-mediated infection. This prompted us to analyze the host reaction of the different resistance sources following mechanical infection with PpO85M (kindly provided by D.J. Robinson). TRV PpO85M (RNA-1 and -2) was used for mechanical inoculation of leaves of all three potato cultivars. The host reaction obtained in PpO85M infected "Russet Burbank" leaves was comparable to PpK20 infection (Fig. 5A). Interestingly, RNA-1 and -2 could not be detected by means of RT-PCR in non-inoculated leaves within 45 dpi (Fig. 2 and RNA-2 data not shown), suggesting that cv. Russet Burbank limited or at least delayed the spread of this isolate. The host reaction observed in PpO85M inoculated "Bintje" leaves was comparable to the HR-like observed after PpK20 infection. We expected that an isolate which can induce tuber spraing should be able to spread from the infection site but neither enlargement of the necrotic lesions nor systemic infection (RT-PCR) were detected in PpO85M infected "Bintje" plants (Fig. 5A and Fig. 2). Although PpO85M induced HR-like cell-death in cv. Saturna and both RNA-1 and -2 could be detected by RT-PCR in inoculated leaves, systemic spread was not observed (Fig. 2 and RNA-2 data not shown). As viral spread and expression of HR-like response did not seem to correlate with the findings of spraing induction in host-pathogen interaction "Russet Burbank"-PpK20 and "Bintje"-PpO85M, these findings prompted us to analyze the avirulence gene functions of isolate PpO85M.

\section{Transient agroexpression of 29K-PpO85M does not induce cell death in "Bintje" leaves.}

PpO85M 29K ORF was cloned into pBIN61S to produce 35S-29K-PpO85M. The subsequent transient expression in leaves of all three cultivars analyzed in this study led to the following observations. As expected, agroexpression of 35S-29K-PpO85M did not induce cell death in either cv. Bintje nor in cv. Russet Burbank (Fig. 5B). In cv. Saturna, however, an HR-like response comparable to constitutive $29 \mathrm{~K}-\mathrm{PpK} 20$ expression could be observed.

\section{Evidence for expression TRV 29K protein in agroinfiltrated leaf tissue.}

To demonstrate the expression of 29K-PpK20 and -PpO85M, both ORFs were translationally fused at the C-terminus with haemagglutinin (HA) tag, cloned into pBIN61S 
(35S-29K-HA-PpK20 and -PpO85M respectively) and used for transient agroexpression $\left(\mathrm{OD}_{600}=1\right)$ in $N$. benthamiana leaf tissue. At 4 dpi total protein extracts were separated by gel electrophoresis and subjected to immunodetection of HA (Fig. 5C). The expression of HA-tagged $29 \mathrm{~K}$ from each isolate was clearly visible compared to protein extracts from untreated and empty vector infiltrated $N$. benthamiana leaf tissue. In order to prove that the 29K HA tag had no influence on the host reaction in the bioassay, 35S-29K-HA-PpK20 and -PpO85M were both used for transient agroexpression in leaves of the three potato cultivars analyzed. Phenotypes were indistinguishable from those induced by untagged $29 \mathrm{~K}$ variants (data not shown).

\section{Sequence comparison of $29 \mathrm{~K}$ proteins encoded by different TRV isolates.}

To date four different isolates of TRV RNA-1 have been sequenced entirely (TRV PpK20: Acc. no. AF406990; TRV PpO85M: Acc. no. AJ586803; TRV SYM: Acc. no. D00155 and TRV ORY: Acc. no. AF034622). From TRV isolate PSG, only the 3' approximate 2077 bp are available, containing the 29K ORF (TRV PSG: Acc. no. X03685). These nucleotide sequences display high sequence homology varying between $92-99 \%$ (data not shown). In order to relate differences in $29 \mathrm{~K}$ recognition as avr-gene from isolates PpK20 and PpO85M to sequence variability on the amino acid level, all available TRV $29 \mathrm{~K}$ sequences were used for ClustalX based alignment (Supplementary Figure 2). The detected sequence homology varied between 95-100\%. 29K-PpO85M displayed the highest sequence divergence of the five isolates (95-98\%) as demonstrated by the outgrouping in the phylogenetic tree (Supplementary Figure 2). Remarkably, the variable amino acids are spread randomly over the $29 \mathrm{~K}$ ORF with one cluster in the central region of the protein between aa position 100114. Direct comparison between $29 \mathrm{~K}-\mathrm{PpK} 20$ and 29K-PpO85M showed difference in 10 amino acid positions, namely V7A, V29M, K54M, D100E, K109R, R112K, K114M, K149R, $\mathrm{P} 225 \mathrm{H}$, and N247K. 

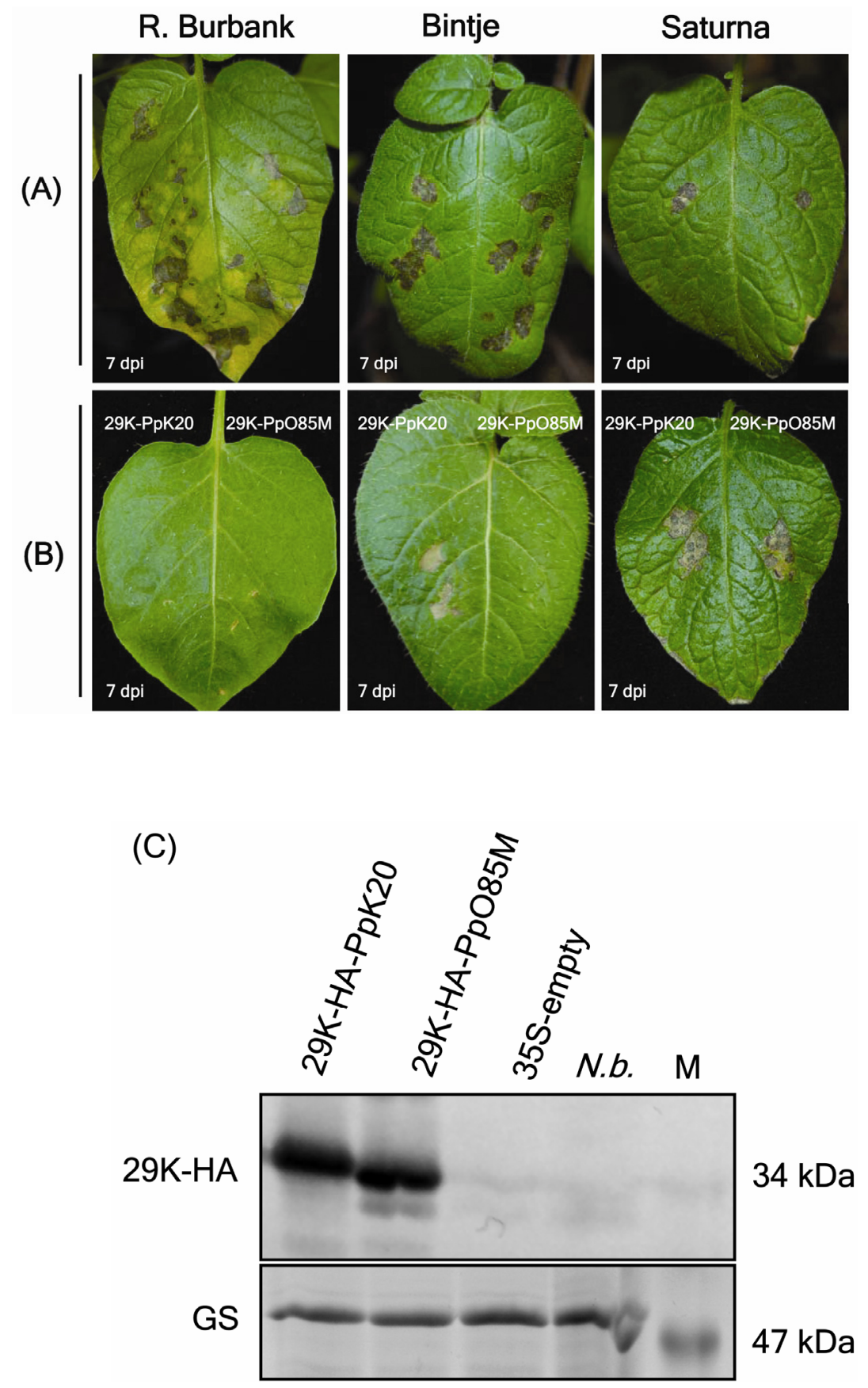

Fig. 5. Host response of "Russet Burbank", "Bintje" and "Saturna" leaves mechanically inoculated with TRV isolate PpO85M and following agroexpression of 29K-PpO85M. A, Leaf host response at 7 dpi following mechanical inoculation with TRV PpO85M infected $N$. clevelandii leaf sap. B, Host response of leaves (7 dpi) agroinfected with 29K-PpO85M ORF (right leaf half) compared to agroinfiltration with 29K-PpK20 (left leaf half). C, 29K-HA: HA immunodetection of TRV 29K in total protein extracts of $N$. benthamiana leaf tissue (4 dpi) infiltrated with $35 \mathrm{~S}$-driven constructs, transiently expressing HA-tagged 29K of isolate PpK20 (29K-HA-PpK20) and isolate PpO85M (29KHA-PpO85M). Untreated (N.b.) and pBIN61S empty vector infiltrated leaf tissue (35S-empty) served as controls, GS: gel staining, M: marker proteins of 34 and $47 \mathrm{kDa}$ respectively. 


\section{DISCUSSION}

To date there have been no clear reports about resistance reactions in potato against TRV which fit into the standard classification of resistance types (Cooper and Jones 1983; Hull 2002) or the nomenclature for potato virus resistance proposed by Valkonen et al. (1996). In a study on susceptibility and resistance of different potato cultivars to infection with two different TRV isolates, we have described for the first time, host reactions which can be assigned to the categories ER, HR-like and spreading necrosis, respectively. In addition to mechanical leaf infection, agroinfection using infectious TRV cDNA clones containing 16K and 29K ORF deletions and expressing a fluorescent marker gene (DsRed) allowed us to study the possible underlying pathogen recognition mechanism by comparing the visual and microscopic observations to known examples of plant virus resistance from similar categories. In general host reaction in potato to virus infection may be temperature-dependent or influenced by other environmental conditions. This has been shown in a temperaturedependent HR response to ER resistance against PVX (Adams et al. 1986a) and HR resistance to PVY (Valkonen 1997). In the experiments carried out here, the inoculated plants were kept under constant temperature of $20-22^{\circ} \mathrm{C}$. Whether host responses in the different cultivars vary with temperature remain to be investigated.

"Russet Burbank" plants reacted with lesions and necrosis spreading to the veins when mechanically infected with TRV-PpK20. Under the environmental conditions applied, the plant was unable to prevent systemic infection, as was demonstrated by DsRed fluorescence around the borders of the spreading lesion and later in non-inoculated leaves. The results of RT-PCR detection of RNA-1 and -2 were in accordance with this finding. The observed phenotype strongly resembled the spreading necrosis observed when TRV is mechanically inoculated on N. tabacum (var. White Burley) (Harrison 1970; Harrison and Robinson 1986). Remarkably, the "Russet Burbank" leaves systemically infected with TRVPpK20 did not show necrosis like the inoculated leaf, but displayed only a slight mosaic. Infection with only RNA-1 was ruled out, since RNA-2 was detectable by RT-PCR. To our knowledge, there is no host reaction to a virus infecting potato described comparable to the reaction we observed in the system TRV-PpK20 vs. "Russet Burbank". However, a similar host reaction was observed by Vidal et al. (2002), who transformed potato with $Y-1$ and obtained a phenotype to mechanical infection with PVY consisting of spreading necrosis and systemic mosaic. The constitutive expression of both genome parts in "Russet Burbank" plants by agroinfection led to a comparable but slightly stronger reaction and faster tissue 
death, which could be explained by the higher inoculum density applied and higher number of initially infected cells.

The observed host reaction following mechanical inoculation of TRV-PpK20 to leaves of cv. Bintje was similar to HR observed in well known monogenic antiviral resistance responses in potato species, i.e. $N b$ and $N x$, both conferring HR to PVX (Cockerham 1970) and HR against several potyviruses (Valkonen 1997). The observation of TRV replication (RT-PCR detection and RNA-2 encoded DsRed fluorescence) in inoculated leaf tissue within 5 dpi before occurrence of visible cell death and lesion formation, as well as, the lack of systemic virus movement supports the hypothesis of HR-like resistance response in cv. Bintje.

The observed lack of virus accumulation without the visible formation of lesions or localized cell death (following mechanical inoculation) in the interaction between TRVPpK20 and plants of the cultivar Saturna strongly resembled the ER observed in potato carrying the monogenic dominant resistance against PVX (Rx1 and Rx2) (Köhm et al. 1993; Ritter et al. 1991). Rxl has been shown to reduce PVX replication strongly on the protoplast level, also affecting the accumulation of co-infecting viruses (Adams et al. 1986b; Bendahmane et al. 1995). Additionally Gilbert et al. (1998) found evidence that the underlying mechanism might suppress the viability of cells. Our observation of TRV-PpK20 rapid arrest supported by the inability to detect RNA-1 and -2 by RT-PCR and to detect RNA-2 encoded-DsRed fluorescence is in full agreement with this typical form of virus resistance in potato (Barker 1996, 1997). Even the observation that $R x 1$ mediated resistance is able to induce secondary HR when the coat protein elicitor of PVX is constitutively expressed (Bendahmane et al. 1999) could be reproduced in our system by transient Agrobacterium-mediated pTRV1 inoculation or expression (transient or virus vector based) of the PpK20 elicitor molecule 29K. This demonstrates that like Rxl the TRV resistance in cv. Saturna possesses the potential to induce secondary HR. It may be concluded that constitutive agroexpression allows replication and subgenomic RNA synthesis to a level sufficient to translate $29 \mathrm{~K}$ in quantities required for visible cell death elicitation.

Our observation of resistance reaction in cv. Saturna, however, contrasts to the reaction observed in PVY inoculated potatoes carrying the $R y_{\text {sto }}$ gene (Ross 1986), despite the fact that $R y_{\text {sto }}$ is classified into the ER category too (Valkonen 1994). In that system, PVY is able to replicate in initially infected cells and move to adjacent cells before cell death and virus spread is stopped (Hinrichs et al. 1998), indicating a resistance mechanism different 
from Rxl and TRV resistance in "Saturna" plants. The finding that "Saturna" reacts to the mechanical PpK20 infection with ER response despite producing HR-like necrotic lesions when leaves are mechanically inoculated with the isolate PpO85M is remarkable and unprecedented. However, the resistance in "Saturna" seems to be able to limit both isolates, PpK20 to the initially infected cell and PpO85M after having spread to several layers of parenchyma cells, as supported by the results of RT-PCR RNA-1 detection. To our knowledge, this is the first report of a resistance response in potato displaying isolate-specific ER and HR-like respectively, giving additional support for a connection of these two resistance classes. In the case of $R x 1$, only a resistance breaking PVX isolate HB has been reported (Kavanagh et al. 1992) but no isolate which induces HR. In soybean a single dominant resistance $R s v-1$ to Soybean mosaic virus (SMV) has been reported, which reacts isolate-specific with ER or spreading necrosis (Hajimorad and Hill 2001; Lim 1985).

Our goal was to identify the avr-gene product of TRV-PpK20 in two potato cultivars displaying resistance responses and inhibiting virus replication ("Saturna”) or restricting virus movement ("Bintje") through the construction and agroinfection of TRV- $\Delta 16 \mathrm{~K}-\mathrm{DsRed}$ and $\Delta 29 \mathrm{~K}-\mathrm{DsR}$ ed. Remarkably, the pTRV- $\Delta 16 \mathrm{~K}$ mutant induced no necrosis in "Russet Burbank" leaves, indicating that the spreading necrosis observed following TRV-1 wild-type might be induced by non-silencing-affected replication and/or significant virus movement. The non-occurrence of necrosis in TRV- $\Delta 29 \mathrm{~K}$-DsRed agroinoculated "Russet Burbank" leaves, together with the finding that transient $29 \mathrm{~K}$ expression provokes no visible host reaction, leads to the conclusion that the spreading necrosis may be induced by the moving virus, probably as ribonucleoprotein (virus RNA in association with 29K). Single cell DsRed expression observed in "Bintje" following infiltration with the $16 \mathrm{~K}$-deletion mutant virus was comparable to that observed in N. benthamiana and the HR-like host reaction was not as pronounced as when induced by wild-type PpK20 infection. Possibly due to RNA silencing, the $29 \mathrm{~K}$ elicitor expression level was impaired which might have affected the strength and speed of the host reaction. Thus, in all three host genotypes, $16 \mathrm{~K}$ was excluded as an elicitor candidate.

The observation of TRV- $\Delta 29 \mathrm{~K}-\mathrm{DsRed}$ replication and non-occurrence of cell death in both resistant cultivars Bintje and Saturna leaves is an indication that $29 \mathrm{~K}$ exhibits the function as an elicitor and was consistent to the observation of cell-death following constitutive $29 \mathrm{~K}$ agroexpression and PVX-based expression. Therefore, the results provide strong evidence that the TRV-29K protein represents the elicitor protein of incompatible 
interactions in the system TRV-PpK20 - "Bintje", TRV-PpK20 - "Saturna" and TRVPpO85M - "Saturna" respectively. The function of $29 \mathrm{~K}$ in the TRV life-cycle is to mediate movement in compatible interactions (Ziegler-Graff et al. 1991). Our results obtained through agroinfection experiments using TRV- $\Delta 29 \mathrm{~K}-\mathrm{DsRed}$ in $N$. benthamiana showed that TRV encoded fluorescence was restricted to single cells, supporting the previous finding of TRV $29 \mathrm{~K}$ movement requirement. At present we do not know whether the genetic basis for resistance in cvs. Bintje and Saturna is inherited by the same factor(s) possibly with different allelic composition(s) leading to a variable gene dosage effect, or by different genes. Therefore, we cannot state whether the $29 \mathrm{~K}$ is the elicitor of one single or two different resistances. Solely the finding that $29 \mathrm{~K}$ proteins from isolates PpK20 and PpO85M, analyzed in this study both trigger HR-like cell-death in cv. Saturna but in contrast only PpK20 encoded $29 \mathrm{~K}$ elicits cell death in $\mathrm{cv}$. Bintje, providing a first indication that the resistance factors might be different. The differences between PpO85M and PpK20 29K comprise 10 amino acid exchanges uniformly distributed throughout the protein sequence, but until now none of these changes can be attributed to the different biological effects observed. Thus, we cannot state whether it is only a domain or the entire protein that is necessary to trigger the host resistance response.

Cultivars with known reaction in respect to spraing have been chosen in this study to elucidate if there is any correlation between the resistance to spraing by natural nematode-mediated infection and the host resistance type(s) induced through leaf-inoculation with TRV. Robinson (2004) investigated nematode-mediated infection of the cultivars Bintje and Saturna (used in our study) with PpK20 and PpO85M, and in the case of PpK20 did not observe the occurrence of spraing..We initially assumed that the spreading necrosis in leaves of cv. Russet Burbank might correlate with the observation of necrotic rings and arcs in the tuber flesh. This presumption was not applicable to the leaf reaction elicited by isolate PpO85M. However, we observed a negative correlation of the cultivars ability to recognize the $29 \mathrm{~K}$ of a particular isolate as avr-gene (when constitutively expressed) and to induce HRlike cell-death, with Robinson's spraing observations following natural nematode-mediated infection. To finally prove the hypothesis that resistance to spraing requires the recognition of the avirulence gene product, it will be necessary to construct PpK20 and PpO85M 29Kchimeras and apply them in nematode-mediated infection experiments. Nevertheless, the ER resistance detected in cv. Saturna seems to be of high practical value to control TRV, because of its effectivity against two isolates displaying highly variable $29 \mathrm{~K}$ elicitor proteins. It 
remains to be tested whether the resistance is elicited by $29 \mathrm{~K}$ proteins derived from other known TRV isolates. Agrobacterium-mediated transient expression of the resistance-elicitor will provide an excellent tool to screen crossing populations as it will yield more reliable information about the susceptibility of breeding lines against TRV infection than resistance assessment in the field in natural infested soils much faster.

\section{MATERIALS AND METHODS}

\section{Growth and propagation of plant material.}

Potato cultivars Russet Burbank, Bintje (Bioplant, Ebstorf, Germany) and Saturna (Saka-Ragis, Windeby) were propagated in vitro following Hussey and Stacey (1981) and Zobayed et al. (2001), except that $0.02 \mathrm{M}$ silver thiosulfate solution (STS) was added to the agar medium to reduce the effect of ethylene. Cultures were kept in a growth chamber at $20^{\circ} \mathrm{C}$ under cool-white fluorescent lamps (photosynthetic photon flux $=100 \mu \mathrm{E} \mathrm{s}^{-1} \mathrm{~m}^{-2}$ ) on a $16 \mathrm{~h}$ photoperiod, acclimatized as described (Valkonen et al. 1991). Plants were transferred into 15-cm-diameter plastic pots, and kept in a growth chamber set for a $16-\mathrm{h}$ day, with a light intensity of $150 \mu \mathrm{E} \mathrm{s}^{-1} \mathrm{~m}^{-2}$ at $20-22^{\circ} \mathrm{C}$, and humidity between $60-70 \%$. Two weeks later, plants were transferred into a glasshouse with day length of $14 \mathrm{~h}$ supplemented with artificial light.

\section{Virus isolates.}

An M-type TRV isolate PpO85M (RNA-1 Acc. no. AJ586803) (Overloon, Netherlands) (Robinson 2004). was propagated on N. clevelandii. DsRed expressing TRV (TRV-DsRed) for mechanical inoculation was obtained from pTRV1 plus pTRV2-DsRed agroinfected N. benthamiana plants.

\section{Viral full-length clones.}

The $2 \times 35 \mathrm{~S}$ promoter driven infectious full-length cDNA clone of TRV RNA-1 isolate PpK20 (complete virus sequence Acc. no. AF406990) in a binary vector for use in agroinfection (pTRV1) and the RNA-2 based virus induced gene silencing vector pTRV2 (pYL156) were first described in Liu et al. (2002b). Plasmid pK20GFPc was described by MacFarlane and Popovich (2000). The binary 35S-PVX plant expression vector (pGr106) has been described 
(Angell and Baulcombe 1997; Lu et al. 2003). PVX vector expressing DsRed (pPVX201optRed) has been described previously (Dietrich and Maiss 2002).

\section{Construction of TRV mutants.}

Standard recombinant DNA techniques used were performed according to Sambrook et al. (1989). pTRV1- $\Delta 16 \mathrm{~K}$ was constructed by deleting the $16 \mathrm{~K}$ ORF from pTRV1 as described previously (Liu et al. 2002a). To generate 35S driven cDNA clone of TRV RNA-2 expressing the CP ORF and DsRed-1 under control of the subgenomic promoter (sgPr) of PEBV CP-gene for agroinfection experiments, an AatII-KpnI fragment containing sgPr, GFP and part of the TRV 3' noncoding region from plasmid pK20GFPc was cloned into pYL156, replacing the MCS of the virus induced gene silencing vector. Thereby, the T7 was replaced by a $2 \times 35 \mathrm{~S}$ promotor and the cDNA clone was rendered suitable for agroinfection experiments. This intermediate plasmid (pYL156-GFP) was tested for infectivity and GFP expression together with pTRV1. Since GFP-expression in potato leaves was low (data not shown), DsRed-1 (pDsRed-C1, Clontech) coding sequence was PCR reamplified, and BspHI and EcoRI flanking restriction sites were introduced. The GFP ORF in pYL156-GFP was replaced using $N c o$ I and EcoRI. The resulting plasmid pTRV2-DsRed together with pTRV1 was tested for infectivity and DsRed fluorescence by means of leaf agroinfiltration in $N$. benthamiana plants. In order to delete the 29K ORF from the RNA-1 cDNA clone, an AvrII (nt. 3234) -SnaBI (nt. 6774) subclone had to be generated from pTRV1. In this subclone, the 29K ORF (nt. 5328-6083) was almost completely removed by digestion with BstEII (nt. 5346) and NarI (nt. 5871), followed by Klenow fill-in reaction and subsequent re-ligation. Back-cloning of $A v r I I-S n a$ BI fragment resulted in pTRV1- $\Delta 29 \mathrm{~K}$. This led to a shortened $29 \mathrm{~K}$ ORF, consisting of seven $29 \mathrm{~K}$ derived amino acids plus seven non-viral amino acids, resulting from the introduced frame shift.

\section{pGr106-29K-PpK20}

For PVX mediated expression of 29K of TRV-PpK20, the 29K ORF was PCR amplified, supplied with flanking restriction sites ClaI and SalI and cloned into pGr106 under control of the doubled sgPr of PVX CP-gene (pGr106-29K-PpK20), and the insert was sequence verified. 


\section{Plasmids for transient agroexpression.}

TRV encoded proteins and DsRed-1 were agroexpressed from pBIN61S (Silhavy et al. 2002) under control of $2 \times 35 \mathrm{~S}$ promoter and polyA-terminator after RT-PCR-reamplification from cDNA clones or total RNA preparations (RNeasy, QIAGEN) from N. benthamiana and N. clevelandii leaves infected with TRV isolates PpK20 and PpO85M, respectively. DsRed-1 ORF was PCR reamplified from pDsRed-C1, cloned, and produced 35S-DsRed. All virus genes were PCR or RT-PCR amplified: PpK20-16K ORF was PCR-supplied with flanking restriction sites (SacI-XbaI) and cloned into pBIN61S (35S-16K). 29K-PpK20 and -PpO85M (756 bps; nt. 5328-6083 in Acc. no. AF406990, nt. 5154-5909 in Acc. no. AJ586803) cloned into pBIN61S were named 35S-29K-PpK20 and 35S-29K-PpO85M. A non-translatable variant of $29 \mathrm{~K}-\mathrm{PpK} 20$ was generated by digesting the $29 \mathrm{~K}$ ORF with $B s t$ EII with subsequent Klenow fill-in and religation, leading to a frame-shift at amino acid (aa) 8 and a stop codon at aa 10. To exclude the translation of a shortened protein translated from internal initiation of the ribosomes, the $29 \mathrm{~K}$ ORF internal XhoI was cut, filled and religated leading to an additional frame-shift at aa 122 and an additional stop codon at aa 127. Backcloning of this non-translatable $29 \mathrm{~K}$ mutant gene into pBIN61S led to 35S-29K-ntr-PpK20. All inserts in clones of TRV-derived PCR fragments were sequence verified using standard primers. Sequencing reactions were carried out by MWG, Martinsried, Germany. For 29K immunodetection, 29K-PpK20 and -PpO85M were C-terminally fused with haemagglutinin (HA) affinity tag (YPYDVPDYA). This was achieved by inserting the HA coding sequence into the lower $29 \mathrm{~K}$ PCR-primer in frame with $29 \mathrm{~K}$ specific nucleotides. The resulting binary vectors were named 35S-29K-HA-PpK20 and -PpO85M respectively. For agroinfection of viral full-length clones and Agrobacterium-mediated transient expression assays, $A$. tumefaciens strains C58C1 (pGV2260) for TRV clones and LBA4404 (pAL4404) for PVX clones were applied, respectively, as described by Voinnet et al. (2000) at a cell density of $3.2 \times 10^{4}$ cells $/ \mathrm{ml}\left(1 / 250\right.$ dilution of $\left.\mathrm{OD}_{600}=1\right)$. For TRV infections, separated cultures containing pTRV1 and pTRV2-DsRed or its derived mutants were mixed in a 1:1 ratio (Ratcliff et al. 2001).

\section{Mechanical inoculation with viruses.}

Systemically infected tobacco leaf-samples with TRV-DsRed and TRV-PpO85M were collected in liquid $\mathrm{N}_{2}$, and stored at $-80^{\circ} \mathrm{C}$ as inoculum source for potato inoculation. For 
mechanical infection of leaves of 4 weeks-old potato plants, plant sap 1/25 diluted in HEPES $(0,03 \mathrm{M}, \mathrm{pH} 7.0)$ was used.

\section{Immunodetection of 29K-HA.}

Total leaf protein extracts from agroinfiltrated leaf patches were obtained by grinding $100 \mathrm{mg}$ $\mathrm{N}_{2}$-frozen leaf-samples with $300 \mu \mathrm{l}$ sample buffer (4 M urea, 4\% SDS, $0.2 \mathrm{M}$ DTT, 20\% glycerol, $0.2 \mathrm{M}$ Tris/HCl [pH 6.8], 0.04 bromophenolblue). Extracted samples ( $5 \mu 1$ each) were separated by SDS-PAGE and electroblotted on PVDF membrane (Roche). Membrane was incubated overnight at $4^{\circ} \mathrm{C}$ in blocking buffer (TBS, $0.1 \%$ Tween-20, 2\% skimmed milk) and washed (TBS, 0.1\% Tween-20). 29K-HA was probed with rat monoclonal antibodies (anti-HA high affinity, Roche, 1:800) and anti-rat IgG alkaline phosphatase (AP) conjugate (Sigma,1:7.000). Detection was performed using chromogenic substrates BCIP (5-bromo-4chloro-3-indolyphosphate, p-toluidine salt) and NBT (nitro blue tetrazolium chloride) reagents (Applichem).

\section{RT-PCR detection of TRV in infected potato leaf tissue.}

Total RNA preparations (RNeasy, QIAGEN) from TRV infected potato leaves were used for RT-PCR detection of RNA-1. Specific primers were designed to amplify the 29K ORF (756 bp). In order to detect RNA-2, CP gene specific primers derived from PpK20 sequence were used, amplifying the exact 621 bp ORF. For 29K-ntr transcript detection in transient agroexpression assays, total RNA preparations were digested with DNase (RQ1, Promega) following the manufacturers instructions before $29 \mathrm{~K}$ specific primers were used in RT-PCR reactions as described above.

\section{Epifluorescence microscopy.}

Spread of TRV expressing DsRed was detected by epifluorescence microscopy (Leica DMR) using specific DsRed filters (Emitter HQ 620/60, Beamsplitter Q 585 LP, Exciter HQ 565/30). Photographs were taken using Leica DFC camera, DFC300 FX. 


\section{ACKNOWLEDGMENTS}

We are grateful to D. J. Robinson for providing TRV isolate PpO85M, and S. A. MacFarlane for the gift of plasmid pK20GFPc. We acknowledge S. P. Dinesh-Kumar for providing pTRV1 and pTRV2 vectors. We thank R. Schuchmann (Bioplant GmbH, Ebstorf, Germany) and SAKA-Ragis Pflanzenzucht GbR (Windeby, Germany) for providing the potato cultivars used in this study. Finally we would like to acknowledge D. Baulcombe for providing PVX plant expression vector pGR106 and E. Maiss for the DsRed-1 expressing PVX variant pPVX201-optRed. This work has been supported by the Scholarship Merit Program, Islamic Development Bank (IDB).

\section{LIETRATURE CITED}

Adams, S. E., Jones, R. A. C., and Coutts, R. H. A. 1986a. Effect of temperature on Potato virus $X$ infection in potato cultivars carrying different combinations of hypersensitivity genes. Plant Pathol. 35:517-526.

Adams, S. E., Jones, R. A. C., and Coutts, R. H. A. 1986b. Expression of Potato virus X resistance gene $R x$ in potato leaf protoplasts. J. Gen. Virol. 67:2341-2345.

Angell, S. M., and Baulcombe, D. C. 1997. Consistent gene silencing in transgenic plants expressing a replicating Potato virus $X$ RNA. EMBO J. 16:3675-3684.

Barker, H. 1996. Inheritance of resistance to Potato viruses $Y$ and $A$ in progeny obtained from potato cultivars containing gene $R y$ : evidence for a new gene for extreme resistance to PVA. Theor. Appl. Genet. 93:710-716.

Barker, H. 1997. Extreme resistance to Potato virus $V$ in clones of Solanum tuberosum that are also resistant to Potato viruses $Y$ and $A$ : evidence for a locus conferring broad-spectrum potyvirus resistance. Theor. Appl. Genet. 95:1258-1262.

Barker, H., and Dale, M. F. B. 2006. Resistance to viruses in potato. Pages 341-366 in: Natural Resistance Mechanisms of Plants to Viruses. G. Loebenstein, and J. P. Carr, eds. Springer, The Netherlands.

Bendahmane, A., Kanyuka, K., and Baulcombe, D. C. 1999. The $R x$ gene from potato controls separate virus resistance and cell death responses. Plant Cell 11:781-791. 
Bendahmane, A., Köhm, B. A., Dedi, C., and Baulcombe, D. C. 1995. The coat protein of Potato virus $X$ is a strain-specific elicitor of $R x 1$-mediated virus resistance in potato. Plant $\mathrm{J}$. 8:933-941.

Cadman, C. H. 1959. Potato stem-mottle disease in Scotland. Eur. Potato J. 2:165--175.

Cadman, C. H., and Harrison, B. D. 1959. Studies on the properties of soil-borne viruses of the Tobacco rattle type occurring in Scotland. Ann. Appl. Biol. 47:542-556.

Cockerham, G. 1970. Genetical studies on resistance to Potato viruses $X$ and $Y$. Heredity 25:309-348.

Cooper, J. I., and Jones, A. T. 1983. Responses of plants to viruses: proposals for the use of terms. Phytopathol. 73:127-128.

Culver, J. N. 1997. Viral avirulence genes. Pages 196-219 in: Plant-Microbe Interactions Vol. 2. G. Stacey, and N. T. Keen, eds. Chapman and Hall, New York.

Dale, M. F. B., Robinson, D. J., Griffiths, D. W., Todd, D., and Bain, H. 2000. Effects of tuber-borne M-type strain of Tobacco rattle virus on yield and quality attributes of potato tubers of the cultivar Wilja. Eur. J. Plant Pathol. 106:275-282.

Dale, M. F. B., and Solomon, R. M. 1988. A glasshouse test to assess the sensitivity of cultivars to Tobacco rattle virus. Ann. Appl. Biol. 112:225-229.

Dietrich, C., and Maiss, E. 2002. Red fluorescent protein DsRed from Discosoma sp. as a reporter protein in higher plants. Biotechniques 32:286-293.

Eibner, R. 1959. Untersuchungen über die 'Eisenfleckigkeit' der Kartoffel. Doctoral dissertation, Justus-Liebig-Universität, Giessen, Germany.

Engsbro, B. 1973. Undersoegelser og forsoeg vedrorende jordbarne vira: I. Rattle-virus, fortsatte undersoegelser i kartofler. Tidsskr. PlAvl. 77:103-117.

Gilbert, J., Spillane, C., Kavanagh, T. A., and Baulcombe, D. C. 1998. Elicitation of $R x$ mediated resistance to PVX in potato does not require new RNA synthesis and may involve a latent hypersensitive response. Mol. Plant-Microbe Interact. 11:833-835.

Hajimorad, M. R., and Hill, J. H.. 2001. Rsvl-mediated resistance against Soybean mosaic virus $-\mathrm{N}$ is hypersensitive response-independent at inoculation site, but has the potential to initiate a hypersensitive response-like mechanism. Mol. Plant-Microbe Interact. 14:587-598. 
Hamilton, W. .D .O., and Baulcombe, D. C. 1989. Infectious RNA produced by in vitro transcription of a full-length Tobacco rattle virus RNA-1 cDNA. J. Gen. Virol. 70:963-968.

Hammond-Kosack, K. E., and Jones, J. D. G. 1996. Resistance gene-dependent plant defense responses. Plant Cell 8:1773-1791.

Harrison, B. D. 1968. Reactions of some old and new British potato cultivars to Tobacco rattle virus. Eur. Potato J. 11:165-176.

Harrison, B. D. 1970. Tobacco rattle virus. CMI/AAB Descr. Pl. Viruses, No. 12, 4 pp.

Harrison, B. D., and Robinson, D. J. 1978. The Tobraviruses. Adv. Virus Res. 23:25-77.

Harrison, B. D., and Robinson, D. J. 1986. Tobraviruses. Pages 339-369 in: The Plant Viruses Vol. 2. M. H. V. van Regenmortel, and H. Fraenkel-Conrat, eds. Plenum Press, New York.

Hernández, C., Visser, P. B., Brown, D. J. F., and Bol, J. F. 1997. Transmission of Tobacco rattle virus isolate $\mathrm{PpK} 20$ by its nematode vector requires one of the two non-structural genes in the viral RNA 2. J. Gen. Virol. 78:465-467.

Hinrichs, J., Berger, S., and Shaw, J. G. 1998. A hypersensitive response-like mechanism is involved in resistance of potato plants bearing the $R y_{\text {sto }}$ gene to the potyviruses Potato virus $Y$ and Tobacco etch virus. J. Gen. Virol. 79:167-176.

Hull, R. 2002. Matthews' Plant Virology. $4^{\text {th }}$ ed. Academic Press, San Diego, CA.

Hussey, G., and Stacey, N. J. 1981. In vitro propagation of potato (Solanum tuberosum L.). Ann. Bot. 48:787-796.

Kang, B.-C., Yeam, I., and Jahn, M. M. 2005. Genetics of plant virus resistance. Annu. Rev. Phytopathol. 43: 581-621.

Kavanagh, T., Goulden, M., Cruz, S. S., Chapman, S., Barker, I., and Baulcombe, D. 1992. Molecular analysis of a resistance-breaking strain of Potato virus X. Virology 189: 609-617.

Köhm, B. A., Goulden, M. G., Gilbert, J. E., Kavanagh, T. A., and Baulcombe, D. C. 1993. A Potato virus $X$ resistance gene mediates an induced, nonspecific resistance in protoplasts. Plant Cell 5:913-920.

Lim, S. M., 1985. Resistance to Soybean mosaic virus in soybeans. Phytopathol. 75:199-201. 
Liu, H., Reavy, B., Swanson, M., and MacFarlane, S. A. 2002a. Functional replacement of the Tobacco rattle virus cysteine-rich protein by pathogenicity proteins from unrelated plant viruses. Virology 298:232-239.

Liu, Y., Schiff, M., Marathe, R., and Dinesh-Kumar, S. P. 2002b. Tobacco Rarl, EDS1 and NPR1/NIM1 like genes are required for $N$-mediated resistance to Tobacco mosaic virus. Plant J. 30:415-429.

Lu, R., Malcuit, I., Moffett, P., Ruiz, M. T., Peart, J., Wu, A. J., Rathjen, J. P., Bendahmane, A., Day, L., and Baulcombe, D. C. 2003. High throughput virus-induced gene silencing implicates heat shock protein 90 in plant disease resistance. EMBO J. 22:5690-5699.

MacFarlane, S. A. 1999. Molecular biology of the tobraviruses. J. Gen. Virol. 80:2799-2807.

MacFarlane, S. A., Brown, D. J. F., and Bol, J. F. 1995. The transmission by nematodes of tobraviruses is not determined exclusively by the virus coat protein. Eur. J. Plant Pathol. 101:535-539.

MacFarlane, S. A., and Popovich, A. H. 2000. Efficient expression of foreign proteins in roots from tobravirus vectors. Virology 267:29-35.

MacFarlane, S. A., Wallis, C. V., and Brown, D. J. F. 1996. Multiple virus genes involved in the nematode transmission of Pea early browning virus. Virology 219:417-422.

Mojtahedi, H., Crosslin, J. M., Santo, G. S., Brown, C. R., and Thomas, P. E. 2001. Pathogenicity of Washington and Oregon isolates of Tobacco rattle virus on potato. Am. J. Potato Res. 78:183-190.

Nimchuk, Z., Eulgem, T., Holt III, B. F., and Dangl, J. L. 2003. Recognition and response in the plant immune system. Annu. Rev. Genet. 37:579-609.

Page, R. D. 1996. TreeView: an application to display phylogenetic trees on personal computers. Comput. Appl. Biosci. 12:357-358.

Ploeg, A. T., Robinson, D. J., and Brown, D. J. F. 1993. RNA-2 of Tobacco rattle virus encodes the determinants of transmissibility by trichodorid vector nematodes. J. Gen. Virol. 74:1463-1466.

Ratcliff, F. G., Hernandez, A. M. M., and Baulcombe, D. C. 2001. Tobacco rattle virus as a vector for analysis of gene function by silencing. Plant J. 25:237-245. 
Reavy, B., Dawson, S., Canto, T., and MacFarlane, S. A. 2004. Heterologous expression of plant virus genes that suppress post-transcriptional gene silencing results in suppression of RNA interference in Drosophila cells. BMC Biotechnol. 4:18.

Ritter, E., Debener, T., Barone, A., Salamini, F., and Gebhardt, C. 1991. RFLP mapping on potato chromosomes of two genes controlling extreme resistance to Potato virus $X$ (PVX). Mol. Gen. Genet. 227:81-85.

Robinson, D. J. 2004. Identification and nucleotide sequence of a Tobacco rattle virus RNA1 variant that causes spraing disease in potato cv. Bintje. J. Phytopathol. 152:286-290.

Robinson, D. J., and Dale, M. F. B. 1994. Susceptibility, resistance and tolerance of potato cultivars to Tobacco rattle virus infection and spraing disease. Aspects Appl. Biol. 39:61-66.

Ross, H. 1986. Potato breeding - problems and perspectives. in: Advances in Plant Breeding. J. Brandes, R. Bartels, J. Völk, and C. Wetter, eds. J. Plant Breed. 13 (suppl.), Pual Parey, Berlin and Hamburg, Germany.

Sambrook, J., Fritsch, E. F., and Maniatis, T. 1989. Molecular cloning: A Laboratory Manual, Cold Spring Harbor Laboratory, Cold Spring Harbor, NY, U.S.A.

Silhavy, D., Molnar, A., Lucioli, A., Szittya, G., Hornyik, C., Tavazza, M., and Burgyán, J. 2002. A viral protein suppresses RNA silencing and binds silencing-generated, 21- to 25nucleotide double-stranded RNAs. EMBO J. 21:3070-3080.

Solomon-Blackburn, R. M., and Barker, H. 2001a. A review of host major-gene resistance to potato viruses $X, Y, A$ and $V$ in potato: genes, genetics and mapped locations. Heredity 86:816.

Solomon-Blackburn, R. M., and Barker, H. 2001b. Breeding virus resistant potatoes (Solanum tuberosum): a review of traditional and molecular approaches Heredity 86:17-35.

Thompson, J. D., Gibson, T. J., Plewniak, F., Jeanmougin, F., and Higgins, D. G. 1997. The CLUSTAL_X windows interface: flexible strategies for multiple sequence alignment aided by quality analysis tools. Nucleic Acids Res. 25:4876-4882.

Valkonen, J. P. T. 1994. Natural genes and mechanisms for resistance to viruses in cultivated and wild potato species (Solanum spp.). Pl. Breeding 112:1-16. 
Valkonen, J. P. T. 1997. Novel resistances to four potyviruses in tuber-bearing potato species, and temperature-sensitive expression of hypersensitive resistance to Potato virus $Y$. Ann. Appl. Biol. 130:91-104.

Valkonen, J. P. T., Jones, R. A. C., Slack, S. A., and Watanabe, K. N. 1996. Resistance specificities to viruses in potato: Standardisation of nomenclature. P1. Breeding 115:433-438. Valkonen, J. P. T., Pehu, E., Jones, M. G. K., and Gibson, R. W. 1991. Resistance in Solanum brevidens to both Potato virus $Y$ and Potato virus $X$ may be associated with slow cell-to-cell spread. J. Gen. Virol. 72:231-236.

Vidal, S., Cabrera, H., Andersson, R. A., Fredriksson, A., and Valkonen, J. 2002. Potato gene $Y-1$ is an $N$ gene homology that confers cell death upon infection with Potato virus $Y$. Mol. Plant-Microbe Interact. 15:717-727.

Voinnet, O., Lederer, C., and Baulcombe, D. C. 2000. A viral movement protein prevents spread of the gene silencing signal in Nicotiana benthamiana. Cell 103:157-167.

Walkinshaw, C. H., and Larson, R. H. 1959. Corky ringspot of potato: a soil-borne virus disease. University of Wisconsin, Agricultural Experiment Station Research Bulletin 217, 31 pp.

Xenophontos, S., Robinson, D. J., Dale, M. F. B., and Brown, D. J. F. 1998. Evidence for persistent, symptomless infection of some potato cultivars with Tobacco rattle virus. Potato Res. 41:255-265.

Ziegler-Graff, V., Guilford, P. J., and Baulcombe, D. C. 1991. Tobacco rattle virus RNA-1 $29 \mathrm{~K}$ gene product potentiates viral movement and also affects symptom induction in tobacco. Virology 182:145-155.

Zobayed, S. M. A., Armstrong, J., and Armstrong, W. 2001. Micropropagation of potato: evalualtion of closed, diffusive and forced ventilation on growth and tuberization. Ann. Bot. 87:53-59. 


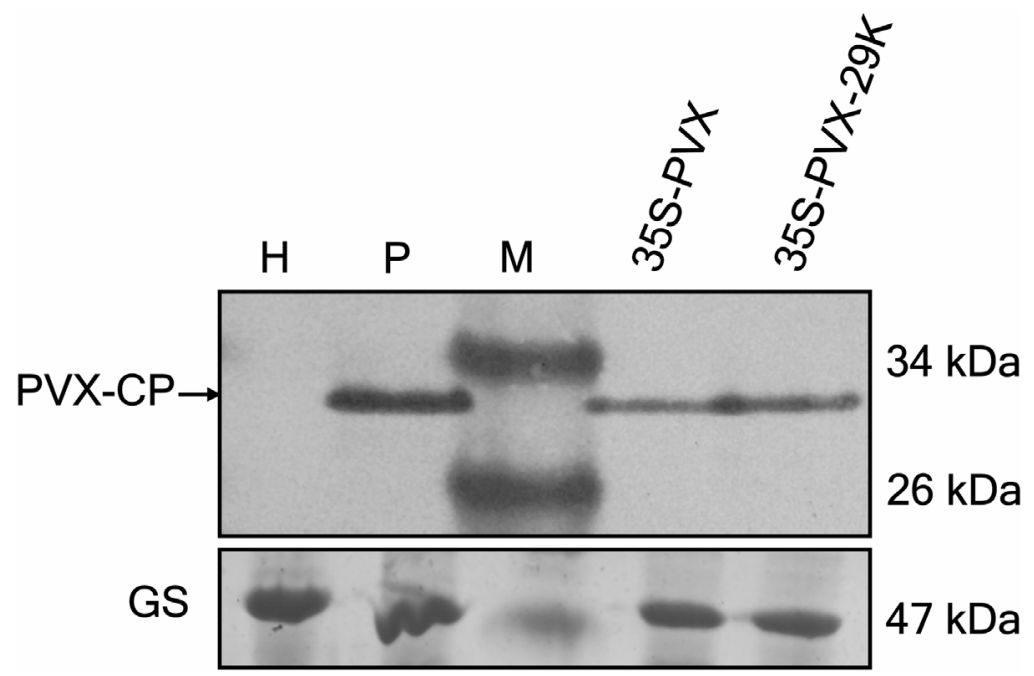

\section{Supplementary Figure 1.}

Immunodetection of $35 \mathrm{~S}-\mathrm{PVX}$ and $35 \mathrm{~S}-\mathrm{PVX}-29 \mathrm{~K}$ encoded $\mathrm{CP}$ in "Russet Burbank" and $N$. benthamiana leaves ( $7 \mathrm{dpi})$. Agroinfection, total protein extraction, separation and immunoblotting was carried out as described in materials and methods. Membrane was probed with PVX-CP specific IgG, and immunodetection carried out as described. H: untreated "Russet Burbank" leaf sample, P: systemic $N$. benthamiana leave sample infected with 35S-PVX served as a positive control; M: prestained marker protein of 34 and $26 \mathrm{kDa}$ respectively. The expected size of PVX-CP is approximately $25.2 \mathrm{kDa}$. GS: gel staining including $47 \mathrm{kDa}$ marker protein. 


\section{(A)}

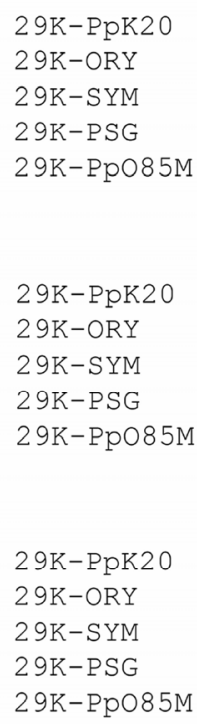

\section{MEDKSLVTLKKKTEEVSKF SNLGAIELE \\ MEDKSLVTLKKKTE EVSKF SNLGAIELE \\ MEDKSLVTLKKKTE EVSKE SNLGAIELE \\ MEDKSL \\ MEDKSL \\ TLKKKTF EVSKF SNLGATELF}

DKRYYF HRRE TVLNHVGG

DGRRKR PKYF HRRRETVLNHVGGK

DGRR KR PKYF HR RRE TVLNHVGGK

GRRKR PKYF HRRRE TVLNHVGGKI

A

80

100

* $\quad 120$

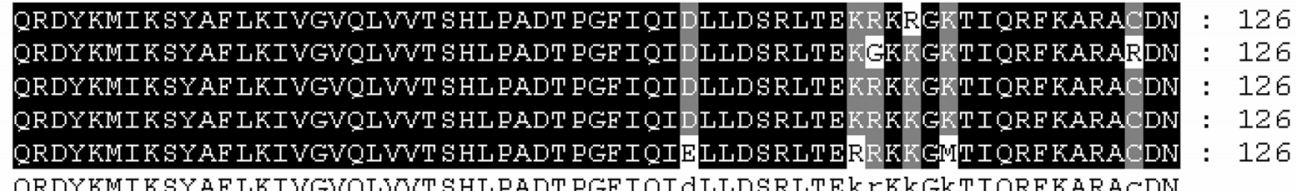

QRDYKMIKSYAF LKIVGVQLVVT SHL PADT PGE IQI dLLDSRLTEKEKKGKTIQRE KARA.CDN

$$
\begin{array}{lllll}
* & 140 & * & 160 & *
\end{array}
$$

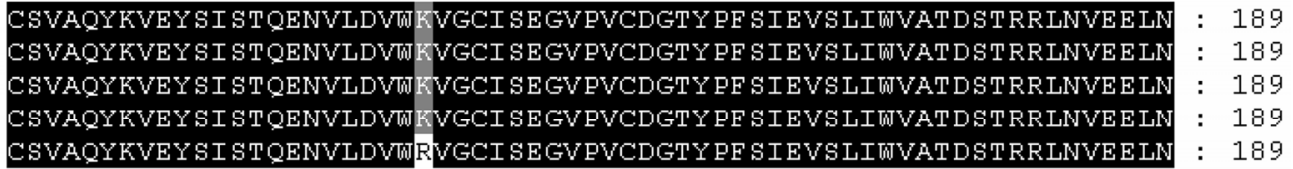

CSVAQYKVEYSISTQENVLDVTKVGCISEGVPVCDGTYPE IEVSLIWVATDSTRRLNVEELN

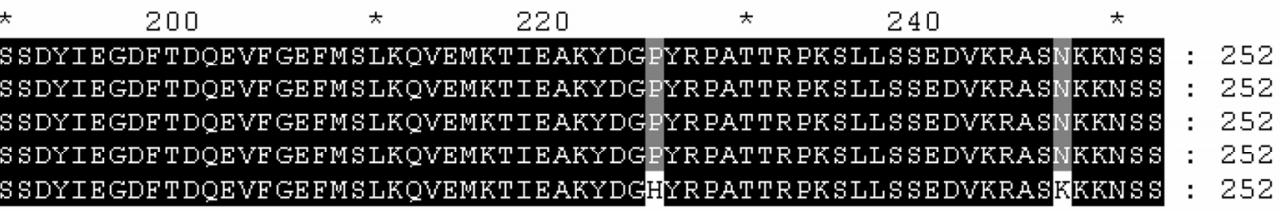

SSDYIEGDETDQEVEGEEMSLKQVEMKTIEAKYDGPYRPATTREKSLLSSEDVKRASnKKNSS

(B)

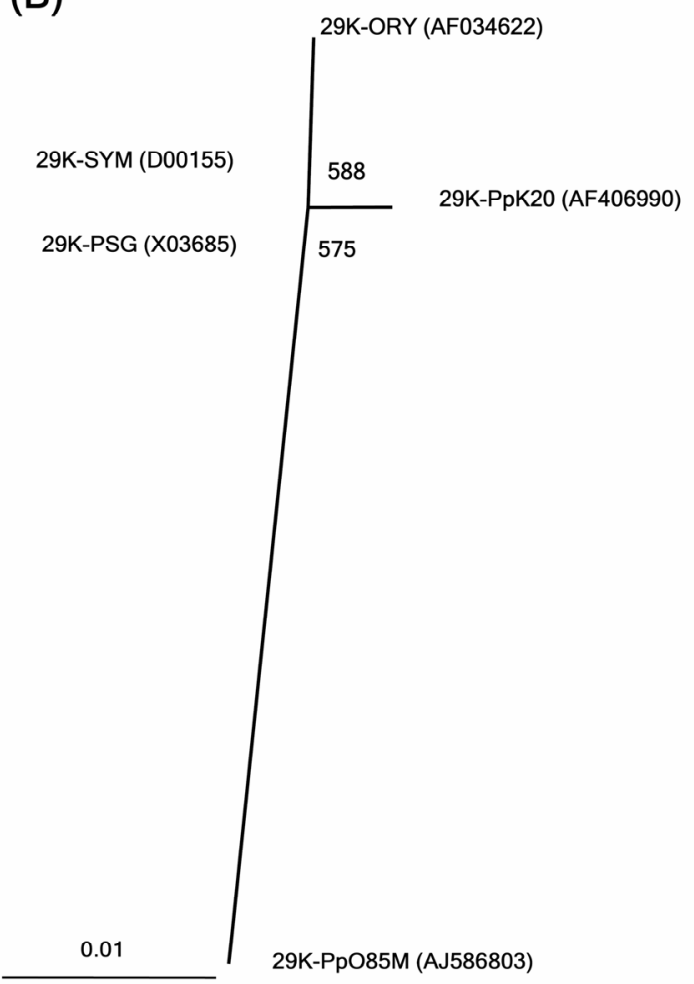

\section{Supplementary Figure 2.}

A, ClustalX alignment (Thompson et al. 1997) of the $29 \mathrm{~K}$ amino acid sequence from 5 different TRV isolates: TRV-PpK20 (Acc. no. AF406990), TRVORY (Acc. no. AF034622), TRV-SYM (Acc. no. D00155), TRV-PSG (Acc. no. X03685) and TRVPpO85M (Acc. no. AJ586803). Gray-colored columns indicate invariant residues between PpK20 and PpO85M isolates. B, Unrooted tree, visualized using the TreeView program (Page 1996), showing the phylogenetic relationships between the aa sequences of the five different $29 \mathrm{~K}$ amino acid sequences. Bootstrap values were calculated from 1000 replicates and are indicated at each node. The scale bar indicates $0.01 \%$ substitution per aa site. 


\title{
CHAPTER 3
}

\section{Functional characterization and subcellular localization of the $16 \mathrm{~K}$ cysteine-rich suppressor of gene silencing protein of Tobacco rattle virus*}

\author{
Walid Ghazala ${ }^{1}$, Angelika Waltermann ${ }^{2}$, Ruth Pilot ${ }^{1}$, Stephan Winter $^{3}$ and Mark Varrelmann ${ }^{1}$ \\ ${ }^{1}$ Department of Crop Sciences, Section Plant Virology, University of Göttingen, \\ Grisebachstraße 6, D-37077 Göttingen, Germany \\ ${ }^{2}$ Institute of Plant Diseases and Plant Protection, Leibniz University of Hannover, \\ Herrenhaeuser Str. 2, D-30419 Hannover, Germany \\ ${ }^{3}$ Plant Virus Department, German Collection of Microorganisms and Cell Cultures (DSMZ), \\ Mascheroder Weg 1b, D-38124 Braunschweig, Germany
}

\section{SUMMARY}

The pathogenicity determinant 16K small cysteine-rich protein (CRP) encoded by RNA-1 of tobacco rattle virus (TRV) is known to partially suppress RNA silencing in Drosophila cells. We show in this study that $16 \mathrm{~K}$ suppresses RNA silencing in green fluorescent protein (GFP)-transgenic Nicotiana benthamiana plants using an Agrobacterium-mediated transient assay. The 16K protein slightly reduced the accumulation of short interfering RNAs (siRNA) of GFP, suggesting that $16 \mathrm{~K}$ may interfere with the initiation and/or maintenance of RNA silencing. Differential analysis of both $\mathrm{N}$ - and C-terminal regions of the protein indicated that the entire 16K open reading frame (ORF) is necessary for the silencing suppression function. Pentapeptide insertion scanning mutagenesis (PSM) revealed that only two short regions of 16K tolerated 5 extra amino acid (aa) insertions without significant reduction in its silencing suppression function. The tolerant regions coincide with sequence variability between tobravirus CRPs, indicating for a strong functional and/or structural conservation of TRV 16K. Confocal laser scanning microscopy (CLSM) analysis of transiently expressed 16K fusions to red fluorescent protein revealed that the full-length $16 \mathrm{~K}$, in addition to cytoplasmic localization, was able to traffic into the nucleus and nucleolus of $N$. benthamiana cells. $16 \mathrm{~K}-$ C-terminal fusion was localized exclusively into the nucleus. In contrast, expression of $16 \mathrm{~K}$ $\mathrm{N}$-terminal region resulted in cytoplasmic retention/nuclear exclusion, indicating that $16 \mathrm{~K}$ possesses two counteracting domains. Analysis of peptide fusions demonstrated that 16K-Cterminal region contains at least two functional bipartite nuclear localization signals (NLSs) which were independently capable of targeting fusions exclusively into the nucleus.

\footnotetext{
* This paper is submitted for publication in Journal of General Virology.
} 


\section{INTRODUCTION}

RNA silencing in higher plants represents a natural host defence response which selectively degrades invading virus RNAs (Voinnet, 2001; Moissiard \& Voinnet, 2004). Replicating plant RNA viruses generate replicative intermediates which temporarily form doublestranded RNAs (dsRNA). These dsRNA molecules are the key trigger molecules of virus induced RNA silencing (Bass, 2000) and processed by an RNase III-type DICER endonuclease (Bernstein et al., 2001) into 21-26 nt double-stranded fragments; the short interfering RNAs (siRNAs) (Hamilton \& Baulcombe, 1999; Elbashir et al., 2001). A multicomponent RNase, the RNA-induced silencing complex (RISC) is guided by the incorporated siRNAs and specifically cleaves complementary single-stranded RNA (ssRNA) (Hammond et al., 2000). Following the local induction of RNA silencing, two different spatial spreadings of the silenced state can be observed: short-distance movement to a limited number of adjacent cells and long-distance movement across the whole plant (Voinnet \& Baulcombe, 1997; Klahre et al., 2002; Himber et al., 2003). Cell-autonomous silencing inactivates genes in cells with accumulated dsRNA, while in non-cell-autonomous silencing a mobile silencing signal is generated that activates or potentiates suppression of homologous mRNAs in cells which are located away from the initiation zone (Voinnet \& Baulcombe, 1997; Palauqui et al., 1997; Mlotshwa et al., 2002; Baulcombe, 2004; Voinnet, 2005).

To counteract this resistance mechanism, plant viruses have evolved proteins that suppress RNA silencing at different stages (Moissiard \& Voinnet, 2004; Silhavy \& Burgyán, 2004; Voinnet, 2005). To date plant virus silencing suppressors are identified from viruses of 23 different genera and with high genetic diversity (Li \& Ding, 2006). The current knowledge on silencing suppressor proteins and the molecular mechanisms of silencing suppression was recently summarized (Moissiard \& Voinnet, 2004; Silhavy \& Burgyán, 2004; Li \& Ding, 2006). The molecular basis for suppressor activity was described for few viruses. Recently siRNA sequestration and dsRNA binding was found as a common mode of action of several suppressor proteins from different plant virus families (Lakatos et al., 2006; Mérai et al., 2006).

Tobacco rattle virus (TRV) is a bipartite positive-sense, single-stranded RNA virus forming rod-shaped particles (MacFarlane, 1999). RNA-1 encodes the 134- and 194-kDa replicase proteins from the genomic RNA, a 29-kDa movement protein (MP) (Ziegler-Graff et al., 1991) and a 16-kDa protein expressed from subgenomic (sg)RNAs. RNA-1 is conserved in size and gene content between isolates and virus species in the genus 
Tobravirus. In contrast RNA-2 displays a high variation between different isolates (MacFarlane, 1999). In nature, TRV is transmitted by soil-inhabiting nematodes (Taylor \& Brown, 1997). The 3'-proximal RNA-1 encodes a cysteine-rich (CRP) 16-kDa protein (16K) with the cysteine-rich region at the $\mathrm{N}$-terminus of the protein, while the $\mathrm{C}$-terminus proves rich in basic residues (MacFarlane, 1999). A general feature of plant RNA virus CRPs (genera Hordeivirus, Furovirus, Pecluvirus, Benyvirus and Tobravirus) is the presence of characteristic sequence motifs including conserved cysteine residues (Morozov et al., 1989; Koonin et al., 1991; Savenkov et al., 1998; Diao et al., 1999; Te et al., 2005). In barley stripe mosaic virus (BSMV) CRP $\gamma b$, two clusters of N-terminal cysteine residues represent zincbinding motifs (Bragg et al., 2004) while the TRV 16K cysteine residues also show some homology to "zinc-finger" proteins (MacFarlane et al., 1989). Some CRPs are involved in seed transmission (Edwards, 1995; Wang et al., 1997) and for a number of CRPs a pathogenicity function and suppressors of gene silencing was demonstrated (Donald \& Jackson, 1994; Dunoyer et al., 2002; Liu et al., 2002a; Yelina et al., 2002; Reavy et al., 2004; Yelina et al., 2005). Another indication for common functions is provided by the functional interchangeability of CRPs between different genera: Hordeivirus, Tobravirus and Furovirus (Liu et al., 2002a; Yelina et al., 2002).

TRV 16K protein is known to be required for efficient replication in $N$. benthamiana protoplasts and enhances potato virus X (PVX) symptoms when expressed from an expression vector (Liu et al., 2002a). TRV was previously shown to suppress transgene silencing in plants in the reversal of silencing assay (Voinnet et al., 1999). Later, TRV 16K was demonstrated to be a pathogenicity determinant (Liu et al., 2002a), and to possess suppressor of gene silencing function in Drosophila cells despite its inability to prevent the accumulation of siRNAs (Reavy et al., 2004). In initial study on $16 \mathrm{~K}$ subcellular localization in tobacco protoplasts it was shown that the protein accumulated in a high-molecular-weight complex, either as a multimer or in association with host proteins (Angenent et al., 1989). Another study demonstrated the localization of $16 \mathrm{~K}$ to be mainly in the nucleus but also in the cytoplasm of TRV infected tobacco cells (Liu et al., 1991).

Our study aimed to determine the silencing suppression function of TRV 16K in planta. Mutagenesis was carried out to relate the cysteine residues, conserved among CRPs, to silencing suppression and to characterize functional domains. Pentapeptide insertion scanning mutagenesis (PSM) (Haapa et al., 1999; Hayes, 2003) was chosen for this purpose, since it has been demonstrated to be a fast and powerful tool for functional characterization 
of plant virus proteins (Varrelmann et al., 2007). Confocal laser scanning microscopy (CLSM) was used to determine the subcellular localization of $16 \mathrm{~K}$ in transient expression assays.

\section{METHODS}

Molecular biology techniques. All recombinant plasmid manipulations were performed as described previously (Sambrook et al., 1989) unless otherwise specified. The identities of all clones obtained were confirmed by sequencing (MWG Biotech AG, Martinsried, Germany).

Clones and infectious transcripts. The binary vector pBIN61S (Silhavy et al., 2002), a derivative of pBIN19 containing an enhanced CaMV 35S-promotor and polyA-terminator cassette was used for transient expression studies. pBIN61S-GFP (35S-GFP) contains the $m g f p 4$ variant with ER targeting signal cloned into in the expression cassette (Haseloff et al., 1997). pBIN61S-tnos-rev is a derivative of pBIN61S obtained by inserting a PCR-amplified nopaline synthase terminator sequence (tnos) in antisense orientation into the EcoRI-site downstream to the polyA-terminator. pBIN61S-GFP-tnos-rev represents the corresponding gfp expressing variant (35S-GFP-tnos-rev). All three plasmids were kindly provided by D. Silhavy. pTRV1 full-length cDNA clone of TRV RNA-1 isolate Ppk20 (GenBank Acc. No. AF406990) under control of the enhanced 35S-promotor and thos in a binary vector was kindly supplied by S. P. Dinesh-Kumar (Liu et al., 2002b). Oligonucleotide primers, used to construct the different plant expression plasmids are shown in Table 1. To generate 35S-16K, the 16K PpK20 141 amino acids (aa) ORF (nt 6111-6536) was PCR amplified from pTRV1 using primers 16K-ORF-5' and -ORF-3', subcloned, sequence verified and cloned into pBIN61S-tnos-rev. In order to express N-terminal aa 1-68 and C-terminal aa 69-141,16Kdeletion mutants under control of the enhanced 35S, the 5' 204 bp of 16K-ORF and the 3' 219 bp respectively, were PCR-amplified using primers $16 \mathrm{~K}-\mathrm{N}-5$ ' and $-\mathrm{N}-3$ ', and 16K-C-5' and $-\mathrm{C}-3$ ' respectively. The $16 \mathrm{~K}$ fusion constructs for subcellular localization were assembled as follows. Initially, the DsRed-ORF was PCR amplified from pDsRed-C1 (Clontech) using primers DsRed1-5' and DsRed1-3', and cloned under control of 35S into binary vector pBIN61S-tnos-rev to give 35S-DsRed-no-stop. Subsequently, 16K-ORF, 16K-N-terminus and $16 \mathrm{~K}$-C-terminus (mentioned above) were cloned into 35S-DsRed-no-stop resulting in 35S-DsRed-16K, $-16 \mathrm{~K}-\mathrm{N}$ and $-16 \mathrm{~K}-\mathrm{C}$, respectively. The coding sequence for three different 
peptides [16K aa 42-51, aa 92-101, SV40 T antigen NLS (Kalderon et al., 1984), see Table 2] were incorporated into the lower primer for DsRed amplification using the upper primer DsRed1-5' in combination with each of the lower primers DsRed-contr-N-3', -contr-C-3' and -SV40-3' respectively. Subsequently, the mutated DsRed amplification products were cloned into pBIN61S-tnos-rev. In order to fuse the peptides coding for 15-17 aa (16K aa 27-41, aa 75-91 and aa 112-128) in frame with DsRed, oligos (NLS1-5' and -3', NLS2-5' and -3', and NLS3-5' and -3', respectively) were hybridised, digested and subsequently cloned into pBIN61S-DsRed-no-stop to yield the plasmids named in Table 2. Monomeric red fluorescent protein (mRFP) (Campbell et al., 2002) was reamplified from pCB-ER-mRFP (kindly provided by J. Carrington) using primers mRFP-5' and mRFP-3' and used to replace DsRed in 35S-DsRed, 35S-DsRed-16K, $-16 \mathrm{~K}-\mathrm{N}$ and -16-C. A summary of fusion constructs generated for subcellular localization experiments is shown in Table 2.

Subcellular localization studies and confocal laser scanning microscopy (CLSM). All 16K fusion constructs were transformed to Agrobacterium tumefaciens C58C1 (pGV2260) and subjected to agro-expression studies. For background visualisation of the cell, all fusion constructs were infiltrated into leaves of transgenic $N$. benthamiana plants (line 16c) expressing endoplasmic reticulum-targeted GFP (GFP-ER) (Brigneti et al., 1998). Confocal imaging of GFP- and DsRed-expressing leaf tissues was performed using a Leica (Heidelberg, Germany) TCS SP2 confocal imaging system with excitation/emission wavelengths (488/510-515 nm) for GFP and (543/600-610 nm) for both DsRed and mRFP respectively.

\section{Random insertion scanning mutagenesis, mapping of the insertion and sequencing.} Generation of a 16K PSM library was carried out using the "Mutation Generation System" F701 MGS $^{\mathrm{TM}}$ (Finnzymes) in a pGEM7ZF(+) (Promega) SacI-XbaI 16K clone, essentially as described by Varrelmann et al. (2007). 16K mutants were cloned into pBIN61S-tnos-rev and the exact position of the pentapeptide insertion of each mutant determined by sequencing.

Plant material and Agrobacterium infiltration. Transgenic N. benthamiana line 16c was used for A. tumefaciens infiltration studies as described previously (Voinnet et al., 2000). For co-infiltrations, equal volumes of both Agrobacterium cultures $\left(\mathrm{OD}_{600}=1\right)$ were mixed prior to infiltration. For single infiltrations, cultures were diluted $1 / 2$ with infiltration buffer. 
Table 1. Oligonucleotide primers used in this study

\begin{tabular}{|c|c|c|}
\hline Name & Sequence $\left(5^{\prime}-3^{\prime}\right)^{*}$ & Introduced sites \\
\hline 16K-ORF-5' & TAAGGTACCATGACGTGTGTACTCAAGGG & KpnI \\
\hline 16K-ORF-3' & ATTCTAGATCAAAAAGCAAACAAACGAT & $X b a \mathrm{I}$ \\
\hline $16 \mathrm{~K}-\mathrm{N}-5$ & TAAGGTACCATGACGTGTGTACTCAAGGG & KpnI \\
\hline $16 k-N-3$ & ATTCTAGAaTCAACGGCCACAACAATTATACA & $X b a \mathrm{I}$ \\
\hline 16K-C-5' & TAAGGTACCATGAGTCACCTTGAAAAGTGTCG & KpnI \\
\hline 16K-C-3' & ATTCTAGAaTCAAAAAGCAAACAAACGAT & $X b a \mathrm{I}$ \\
\hline DsRed1-5' & ATGAGCTCATGGTGCGCTCCTCCAAGAAC & SacI \\
\hline DsRed1-3' & ATGAGCTCCAGGAACAGGTGGTGGCGG & $\mathrm{SacI}$ \\
\hline DsRed-contr-N-3' & $\begin{array}{l}\text { ATTCTAGATCAGACAAACCATCCACAATTATTTTCCGCA } \\
\text { CACAGGAACAGGTGGTGGCGG }\end{array}$ & $X b a \mathrm{I}$ \\
\hline DsRed-contr-C-3' & $\begin{array}{l}\text { ATTCTAGATCAAGCTGTCGCAGACATGTTTTCAGCTTGA } \\
\text { TTCAGGAACAGGTGGTGGCGG }\end{array}$ & $X b a \mathrm{I}$ \\
\hline DsRed-SV40-3' & $\begin{array}{l}\text { ATTCTAGATCAAACCTTTCTTTTCTTTTTTGGCAGGAACA } \\
\text { GGTGGTGGCGG }\end{array}$ & $X b a \mathrm{I}$ \\
\hline NLS1-5 & $\begin{array}{l}\text { TAAGGTACCAAATTGCGAAAGCAAGTTGCTGACATGGTT } \\
\text { GGTGTCACACGTAGGTGATTCTAGAAT }\end{array}$ & $K p n \mathrm{I}, X b a \mathrm{I}$ \\
\hline NLS1-3' & $\begin{array}{l}\text { ATTCTAGAaTCACCTACGTGTGACACCAACCATGTCAGCA } \\
\text { ACTTGCTTTCGCAATTTGGTACCTTA }\end{array}$ & $X b a \mathrm{I}, K p n \mathrm{I}$ \\
\hline NLS2-5 & $\begin{array}{l}\text { TAAGGTACCAAGTGTCGTAAACGTGTTGAAACAAGAAA } \\
\text { TCGAGAAATTTGGAAACAAATTCGACGATGATCTAGAAT }\end{array}$ & $X b a \mathrm{I}, K p n \mathrm{I}$ \\
\hline NLS2-3' & $\begin{array}{l}\text { ATTCTAGAaTCATCGTCGAATTTGTTTCCAAATTTCTCGA } \\
\text { TTTCTTGTTTCAACACGTTTACGACACTT } \underline{\text { GTACCTTA }}\end{array}$ & $X b a \mathrm{I}, K p n \mathrm{I}$ \\
\hline NLS3-5' & $\begin{array}{l}\text { TAAGGTACCAAGAAGAAATTCAAAGAGGACAGAGAATT } \\
\text { TGGGACACCAAAAAGATTTTTAAGATGATTCTAGAAT }\end{array}$ & $X b a \mathrm{I}, K p n \mathrm{I}$ \\
\hline NLS3-3' & $\begin{array}{l}\text { ATTCTAGAaTCATCTTAAAAATCTTTTTGGTGTCCCAAAT } \\
\text { TCTCTGTCCTCTTTGAATTTCTTCTT } \underline{\text { GTACCTTA }}\end{array}$ & $X b a \mathrm{I}, K p n \mathrm{I}$ \\
\hline mRFP-5' & ATGAGCTCATGGTGCGCTCCTCCAAGAAC & SacI \\
\hline mRFP-3' & ATGAGCTCCAGGAACAGGTGGTGGCGG & $\mathrm{SacI}$ \\
\hline
\end{tabular}

*Introduced restriction sites are underlined and introduced ATG- and stop-codons are italicised. Lowercase nucleotides indicate additional non-target sequence nucleotides. 
Table 2. Fusion constructs assembled for subcellular localization experiments

\begin{tabular}{lll}
\hline Construct name & 16K aa numbers applied & Amino acid (aa)-sequence \\
\hline 35S-DsRed & n.a. & n.a. \\
35S-DsRed-NLS-SV40 & n.a. & PKKKRKV \\
35S-DsRed-16K-75-91 & $16 \mathrm{~K}-75-91$ & ${ }^{75}$ RKRVETRNREIWKQIRR \\
35S-DsRed-16K-112-128 & $16 \mathrm{~K}-112-128$ & ${ }^{112}$ KKFKEDREFGTPKRFLR $^{128}$ \\
35S-DsRed-16K-27-41 & $16 \mathrm{~K}-27-41$ & ${ }^{27}$ KLRKQVADMVGVTRR $^{41}$ \\
35S-DsRed-16K-42-51 & $16 \mathrm{~K}-42-51$ & ${ }^{42}$ CAENNCGWFV $^{51}$ \\
35S-DsRed-16K-92-101 & $16 \mathrm{~K}-92-101$ & ${ }^{92}$ NQAENMSATA $^{101}$ \\
35S-DsRed-16K & $16 \mathrm{~K}-1-141$ & $1-141$ \\
35S-DsRed-16K-N & $16 \mathrm{~K}-1-68$ & $1-68$ \\
35S-DsRed-16K-C & $16 \mathrm{~K}-69-141$ & $69-141$ \\
35S-mRFP & n.a. & n.a. \\
35S-mRFP-16K & $16 \mathrm{~K}-1-141$ & $1-141$ \\
35S-mRFP-16K-N & $16 \mathrm{~K}-1-68$ & $1-68$ \\
35S-mRFP-16K-C & $16 \mathrm{~K}-69-141$ & $69-141$ \\
\hline
\end{tabular}

n.a: not applicable

\section{Transient silencing suppression assay, GFP visualization and RNA gel blot analysis.}

Transient silencing suppression assay and northern blot analysis of GFP-mRNA and GFPspecific siRNA were performed as described previously (Varrelmann et al., 2007).

Sequence analysis. Sequence alignment was carried out using the neighbour joining algorithms in the ClustalX version 1.83 program (Thompson et al., 1997).

16K antiserum production. 16K ORF was PCR amplified from pTRV1 and cloned into the pET28a(+) vector (Novagen) using introduced flanking sites SacI and HindIII in frame with the N-terminal 6x histidin-tag sequence. This resulted in 38 additional N-terminal amino acids increasing the $16 \mathrm{~K}$ size to a calculated molecular weight of $20.3 \mathrm{kDa}$. Expression of the $16 \mathrm{~K}$ protein in E. coli BL21 (DE3) cells showed the His-tagged fused $16 \mathrm{~K}$ protein to be in the insoluble cytoplasmic fraction from where it was subsequently purified using the BugBuster ${ }^{\circledR}$ (Novagen) reagent. The recombinant fusion protein was purified under denaturing conditions by affinity chromatography using the Ni-NTA HisBind ${ }^{\circledR}$ Resin (Novagen) and finally dialyzed against 1x PBS. For immunization, $50 \mu \mathrm{g}$ of the purified 16K protein was emulsified with an equal volume of Freund's incomplete adjuvans (Sigma), prior to 3 intramuscular injections at two-week intervals. After a booster, 4 weeks after the last injection, blood was taken from the lateral ear vein at two-week intervals. From the resulting antiserum, IgG antibodies were purified on protein A columns (HI Trap protein A HP, GE Healthcare, Munich, Germany). This purified $\mathrm{IgG}$ was used for western blot analysis. 
Protein extraction and immunoblot analysis. Total plant proteins from agroinfiltrated $N$. benthamiana patches were extracted under denaturing conditions essentially as described (Albrecht et al., 1988). Extracted samples were separated by 15\% SDS-PAGE and electroblotted on nitrocellulose membranes (Protran, Schleicher and Schuell) as previously described (Towbin et al., 1979). TRV 16K was probed with anti-16K rabbit polyclonal antiserum $(2 \mathrm{mg} / \mathrm{ml} \mathrm{IgG})$ which was subsequently detected using a goat anti-rabbit alkaline phosphatase conjugated polyclonal antibody (Sigma) at a 1:10.000 (v/v) dilution). Chromogenic detection was performed as described (Varrelmann et al., 2007).

\section{RESULTS}

TRV 16K suppresses RNA silencing in the transient silencing suppression assay in GFPtransgenic $N$. benthamiana. The TRV $16 \mathrm{~K}$ gene cloned in a binary plant expression vector (pBIN61S-tnos-rev, see comment for this vector below in the MGS library section) was used in the silencing suppression assay (35S-16K + 35S-GFP) using parallel infiltrated 35S-GFP and $35 \mathrm{~S}-16 \mathrm{~K}$ for GFP-fluorescence control. Agroinfiltration of 35S-GFP led to a visible increase of GFP expression at 3 dpi followed by silencing of the GFP transgene induced at 5 dpi, leading to strong reduction of green fluorescence inside the infiltrated areas and cellautonomous RNA silencing represented by a red ring of GFP-silenced cells around coinfiltrated patches (Voinnet \& Baulcombe, 1997) (Fig.1a). At 3 dpi, GFP-specific siRNAs were detectable and their concentration increased until 7 dpi, while GFP mRNA accumulation in the infiltrated areas was reduced at 5 dpi (Fig.1b). In 35S-16K + 35S-GFP co-infiltrated patches, both GFP fluorescence and mRNA expression remained more or less stable at a high level up to 7 and 5 dpi respectively, indicating that $16 \mathrm{~K}$ prevented GFP mRNA degradation. Northern blot analysis of 21-25 bp GFP specific siRNAs showed a reduction of GFP siRNA accumulation compared to 35S-GFP (Fig. 1b). Gene silencing of GFP and characteristic red-rings around infiltrated patches was observed not earlier than 10 dpi (data not shown). GFP-expression was not altered by 35S-16K expression and there were no changes found in the transgenic GFP mRNA level and accumulation of GFP siRNA, thus served as a control to monitor basal GFP expression. To prove expression of $16 \mathrm{~K}$, protein samples were extracted at 3, 5 and $7 \mathrm{dpi}$, separated by SDS-PAGE and used for $16 \mathrm{~K}$ detection in immunoblot analysis with $16 \mathrm{~K}$ specific antiserum (Fig. 1c). Subsequently, we aimed to define regions or domains in the TRV $16 \mathrm{~K}$ protein necessary for silencing suppression; hence 16K-N-terminal and C-terminal deletion mutants were transiently 
expressed in GFP-transgenic $N$. benthamiana plants, as described above. In both cases, UVmonitoring at 3 and 5 dpi revealed cell-autonomous and non-autonomous RNA silencing. Analysis of GFP-mRNA and -siRNA accumulation showed that expression of both N- and Cterminus did not increase GFP mRNA and had no influence on the occurrence of siRNAs (data not shown). Therefore, PSM was applied as an alternative mutagenesis approach.
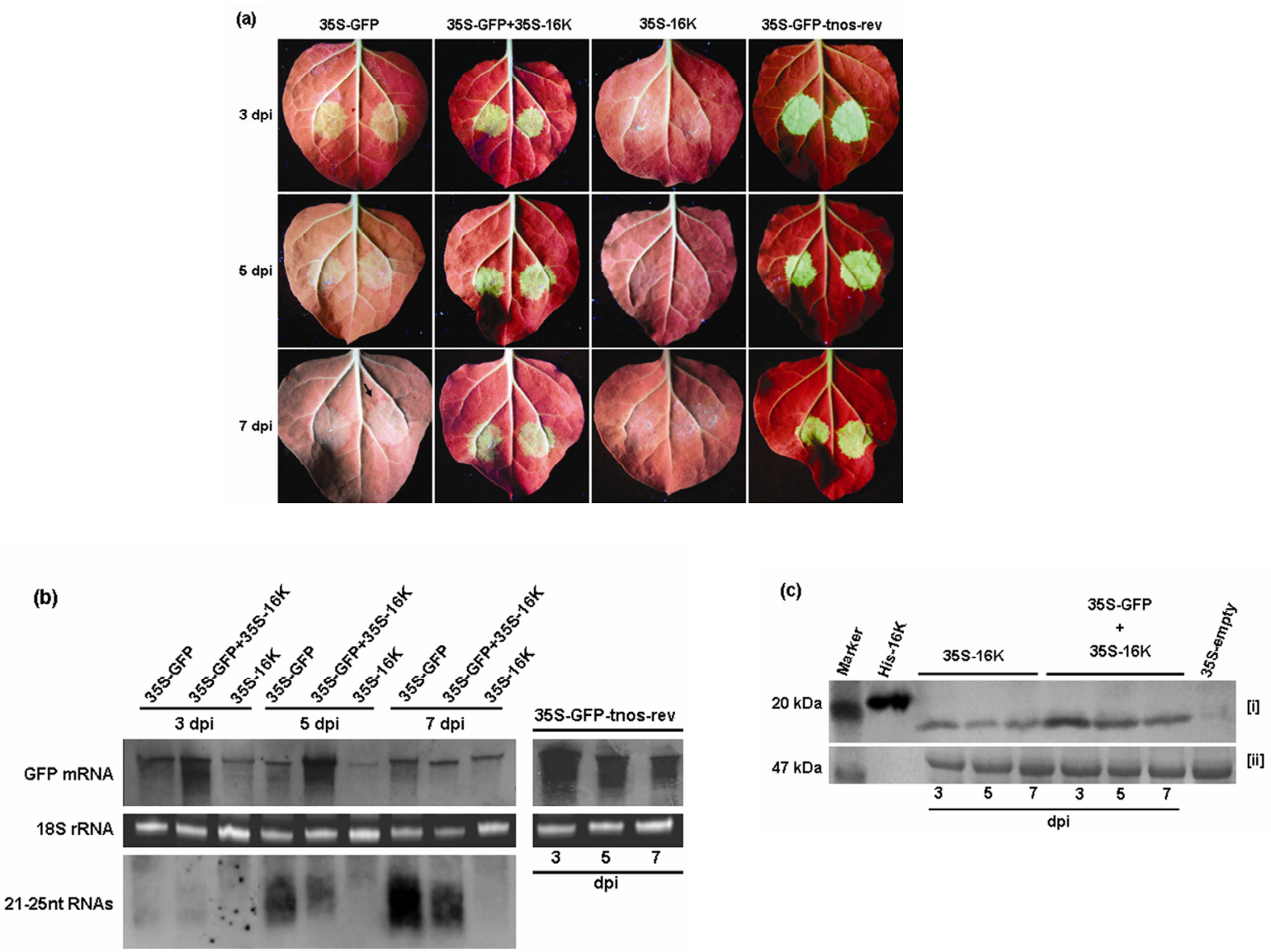

Fig. 1. Effect of TRV 16K on transgene-induced RNA silencing in GFP-transgenic N. benthamiana line $16 \mathrm{c}$ plants. (a) Leaves were infiltrated with $35 \mathrm{~S}-\mathrm{GFP}$, co-infiltrated with $35 \mathrm{~S}-\mathrm{GFP}+35 \mathrm{~S}-16 \mathrm{~K}$, 35S-16K and 35S-GFP-tnos-rev respectively. GFP expression under UV-illumination is shown at 3, 5 and $7 \mathrm{dpi}$. Local silencing of GFP is manifested in reduction of transient additional fluorescence in the patch. Thin red line without fluorescence (black arrow) outside the infiltrated area indicates cell-tocell RNA silencing. (b) Northern analysis showing GFP-mRNA and -siRNA (21-25 bps) accumulation in infiltrated leaf areas. 35S-16K infiltration shows transgenic GFP-mRNA without induction of local RNA silencing. Only slight reduction of GFP-mRNA was observed in 35S-GFP-tnos-rev patches compared to 35S-GFP. Equal loading of the gel was verified by ethidium bromide staining of $18 \mathrm{~S}$ RNA. (c) Immunodetection of TRV $16 \mathrm{~K}$ protein with antiserum raised against bacterial expressed protein in infiltrated leaf areas [i], and corresponding PAGE loading control [ii]. 35S-empty: infiltration with pBIN61S; His-16K: bacterially expressed and column chromatography purified TRV 16K N-terminal 6x Histidin-tagged (calculated size: 20.39-kDa). 
PSM based construction of a linker scanning library of TRV 16K. To analyse 16K for specific domains involved in silencing suppression, a library of random pentapeptide insertions in the TRV PpK20 16K gene was constructed to test the tolerance of the silencing suppressor function of the $16 \mathrm{~K}$ protein to 5 aa insertions at random positions. As a result of the mutagenesis reaction 100 transformants were isolated, pooled and cloned into pBIN61Stnos-rev. This plasmid was chosen to prevent that defective silencing suppression PS proteins are themselves targeted by RNA silencing. Kertesz et. al. (unpublished data) have shown that agroinfiltration mediated transgene-induced silencing can be prevented if the transgene is expressed from a binary vector having double-terminator sequences (a sense $35 \mathrm{~S}$ polyA and an antisense oriented nos terminator). To prove this vector ability, a pBIN61S-tnos-rev expressing GFP (35S-GFP-tnos-rev) was agroinfliltrated into GFP-transgenic $N$. benthamiana plants and resulted in strong GFP fluorescence (Fig. 1a) with strong GFP mRNA expression level up to 7 dpi (Fig. 1b) demonstrating its suitability to serve for the expression of the PS library mutants. Evaluation of the entranceposon footprint permitted the selection of 58 clones with insertions randomly spread over the $16 \mathrm{~K}$ ORF. Sequence evaluation (Table 3) showed that 30 of the 58 sequenced PSM mutants represented independent isolations with 28 mutants isolated twice from the initial library. Moreover, the 15 nucleotide entranceposon footprint at different nucleotide positions in the $16 \mathrm{~K}$ gene led to pentapeptide insertions in 2 cases at the identical amino acid position with varying composition (41::AAATR and CGRTR, 56::CGRII and AAAVI). Since 30 different mutants were selected from the initial $16 \mathrm{~K}$ mutant library, an average of one insertion per 4.7 aa was generated.

Transient silencing suppression assay of $16 \mathrm{~K}$ PS mutants. A transient silencing suppression assay was conducted for the 30 independent mutants in three repetitions using two plants for each experiment. Transient GFP fluorescence was monitored under UV-light at 3, 5 and 7 dpi and compared to parallel infiltrated TRV 16K wild-type (35S-16K + 35S-GFP) and silencing of GFP-transgenic $N$. benthamiana infiltrated with 35S-GFP. Non-functional 16K PS mutants with no detectable silencing suppression activity, i.e. strong reduction of GFP-fluorescence in the infiltrated area at 5 dpi were grouped into Class III; 16K PS mutants with restricted functionality (increased GFP-fluorescence) were assigned to Class II, and PS mutants with strong GFP-fluorescence similar to wild-type fluorescence were grouped into Class I (Table 3). 
Table 3. Effect of entranceposon insertion mutations in TRV $16 \mathrm{~K}$ on silencing suppression ability in transgene-induced RNA silencing assay

\begin{tabular}{|c|c|c|c|}
\hline $\begin{array}{c}16 K \\
\text { mutant no. }\end{array}$ & $\begin{array}{l}\text { TRV } 16 \mathrm{~K} \text { aa followed by } \\
\text { inserted pentapeptide }\end{array}$ & Inserted pentapeptide & Mutant class \\
\hline 1 & 1 & MRPQL & II \\
\hline 2 & 7 & VRPHK & III \\
\hline 3 & 8 & AAAQG & III \\
\hline 4 & 13 & AAAEV & I \\
\hline 5 & 16 & AAAVL & I \\
\hline 6 & 20 & CAAAT & II \\
\hline 7 & 21 & AAATC & III \\
\hline 8 & 22 & CGRSS & III \\
\hline 9 & 24 & CGRIG & III \\
\hline 10 & 25 & CGRSH & III \\
\hline 11 & 29 & LRPQL & III \\
\hline 12 & 31 & AAAQV & III \\
\hline 13 & 38 & AAAVG & III \\
\hline 14 & 41 & AAATR & III \\
\hline 15 & 41 & CGRTR & III \\
\hline 16 & 42 & CGRSR & III \\
\hline 17 & 44 & VRPHA & III \\
\hline 18 & 53 & AAAVC & III \\
\hline 19 & 54 & CGRSV & III \\
\hline 20 & 56 & CGRII & III \\
\hline 21 & 56 & AAAVI & III \\
\hline 22 & 57 & AAAIN & III \\
\hline 23 & 69 & MRPHR & III \\
\hline 24 & 76 & MRPHR & III \\
\hline 25 & 93 & CGRRN & I \\
\hline 26 & 99 & VRPQS & I \\
\hline 27 & 100 & CGRTA & II \\
\hline 28 & 102 & AAATA & II \\
\hline 29 & 110 & SAAAT & I \\
\hline 30 & 135 & AAAFG & III \\
\hline
\end{tabular}

To test if PSM interfered with protein stability, total protein was extracted (5 dpi) from agroinfiltrated patches of all 30 35S-16K PS mutants and 35S-16K + 35S-GFP and subjected to immunoblot analysis as described above. Expression of $16 \mathrm{~K}$ protein was proven for all mutants tested, independent of their silencing suppression activity (Fig. 2).

Effect of different TRV 16K PS mutants on the GFP-mRNA accumulation. 10 PS mutants (16K amino acid position followed by pentapeptide insertion (13::AAAEV, 16::AAAVL, 20::CAAAT, 29::LRPQL， 31::AAAQV， 57::AAAIN， 76::MRPHR, 93::CGRRN, 99::VRPQS and 110::SAAAT) were chosen for a more detailed analysis and tested for their effect on accumulation of GFP-mRNA and to verify the results of the UVmonitoring (displayed in Table 3). Slight differences between mRNA level and visual observation of GFP expression level were observed (Fig. 3a, b), which was probably due to 
variation within the assay as shown in the independent repetitions (data not shown). Mutants displaying a Class II phenotype maintained GFP-mRNA levels at 5 dpi higher than the control infiltrations with $35 \mathrm{~S}-\mathrm{GFP}$ but in most cases lower than the $16 \mathrm{~K}$ wild-type control. 16K Class III mutants did not influence GFP-mRNA level at 5 dpi and were similar to 35S-GFP.

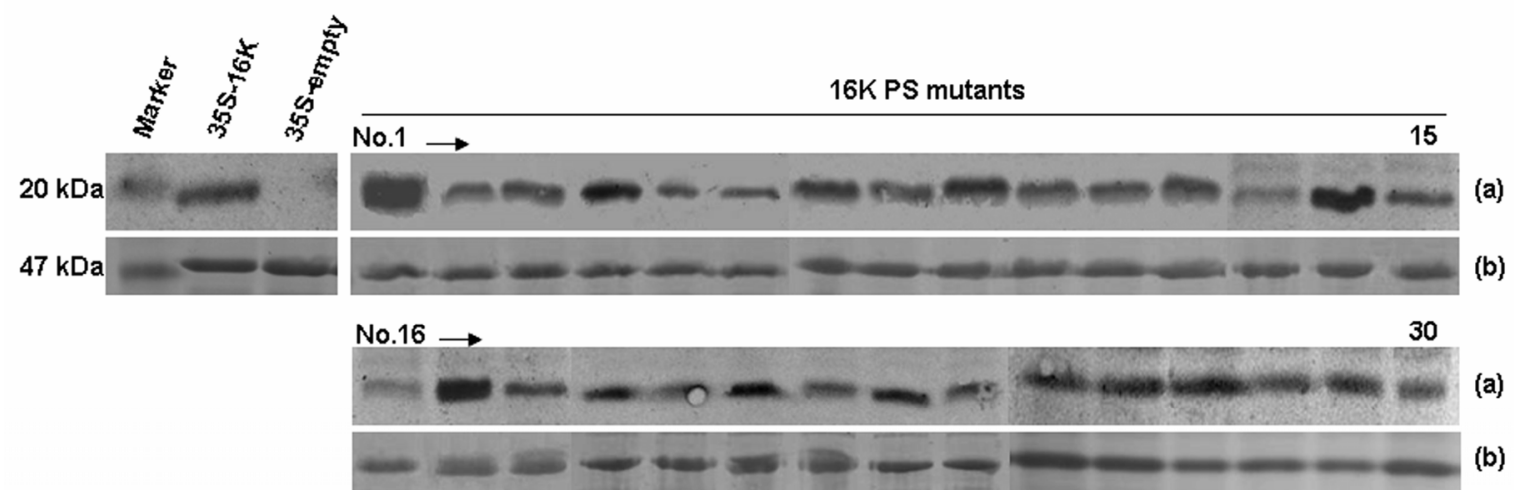

Fig. 2. Expression analysis of the 30 TRV 16K PS mutants co-infiltrated with 35S-GFP in transgenic $16 \mathrm{c}$ plants. (a) Immunodetection of $16 \mathrm{~K}$ in total protein extracts (5 dpi) using polyclonal antiserum. 35S-16K and 35S-empty (pBIN61S) infiltrated leaves served as positive and negative control, respectively. (b) PAGE loading control.

Construction of a functional map of TRV $16 \mathrm{~K}$ for silencing suppression motifs. Since visual examination of GFP expression and mRNA-levels of the 10 mutants analysed correlated well, the UV-examination results of the remaining 22 mutants were included to map the effect of $16 \mathrm{~K}$ ORF pentapeptide insertions on suppression of transgene-induced RNA silencing (Fig.3c; Table 3). 5 of the PS-mutants revealed similar expressions than the wild-type $16 \mathrm{~K}$ protein (Class I), 4 mutants were assigned to Class II and 21 showed no silencing suppression function at all (Class III). Remarkably, mutants which retained at least some silencing suppression ability were detected only in two regions of the protein namely in the region covering aa 13-20 (1::MRPQL, 13::AAAEV, 16::AAAVL, 20::CAAAT) and aa 93-110 (93::CGRRN, 99::VRPQS, 100::CGRTA, 102::AAATA, 110::SAAAT), labelled as "+" in Fig. 4. The remaining parts of the protein including cysteine, glycine and histidine residues conserved in CRPs (Savenkov et al., 1998) (aa position 42, 47, 48, 66, 67 and 70, labelled in Fig. 4) were functionally intolerant for pentapeptide insertions. 
(a)

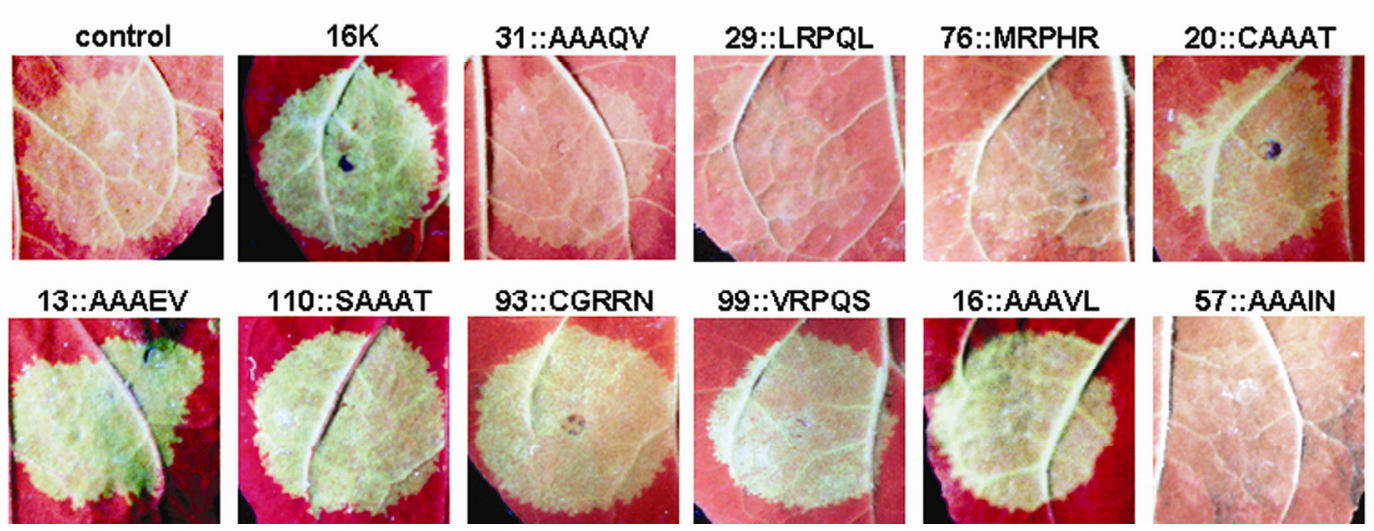

(b)

\begin{tabular}{|c|c|c|c|c|c|c|c|c|c|c|c|}
\hline \multirow[b]{2}{*}{ 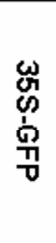 } & \multirow[b]{2}{*}{ 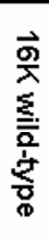 } & \multicolumn{10}{|c|}{ 35S-GFP + 35S-16K PS mutants } \\
\hline & & 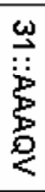 & 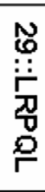 & 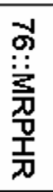 & $\begin{array}{l}\stackrel{N}{0} \\
\stackrel{\leftrightarrow}{8} \\
\stackrel{8}{8}\end{array}$ & 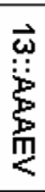 & 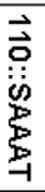 & 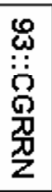 & 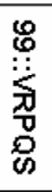 & & \\
\hline & & III & & III & $\|$ & & 1 & & & & \\
\hline
\end{tabular}

mRNA

18S RNA

(c)
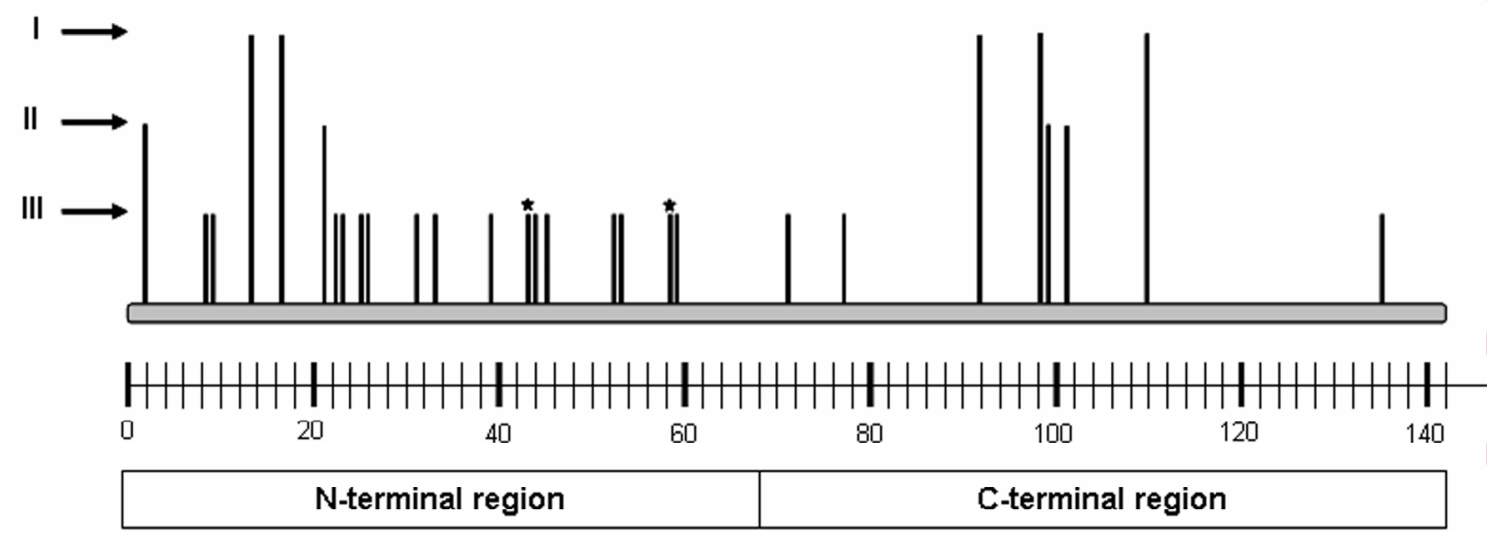

Fig.3. (a) GFP expression in 35S-GFP co-infiltrated GFP-transgenic $N$. benthamiana line $16 \mathrm{c}$ leaves with 10 selected 16K PS mutants under UV-illumination (5 dpi), compared to $35 \mathrm{~S}-16 \mathrm{~K}$ wild-type (16K) and 35S-GFP alone (control). (b) GFP-mRNA accumulation at 5 dpi. (c) Functional map of TRV 16K isolate PpK20. 16K PS mutants created in this study displaying different levels of silencing-suppressor ability (classes I-III: see, descriptions in the text and Table 3). ( $\star$ ) indicates for two independent insertion mutants at the same amino acid position with varying composition. 


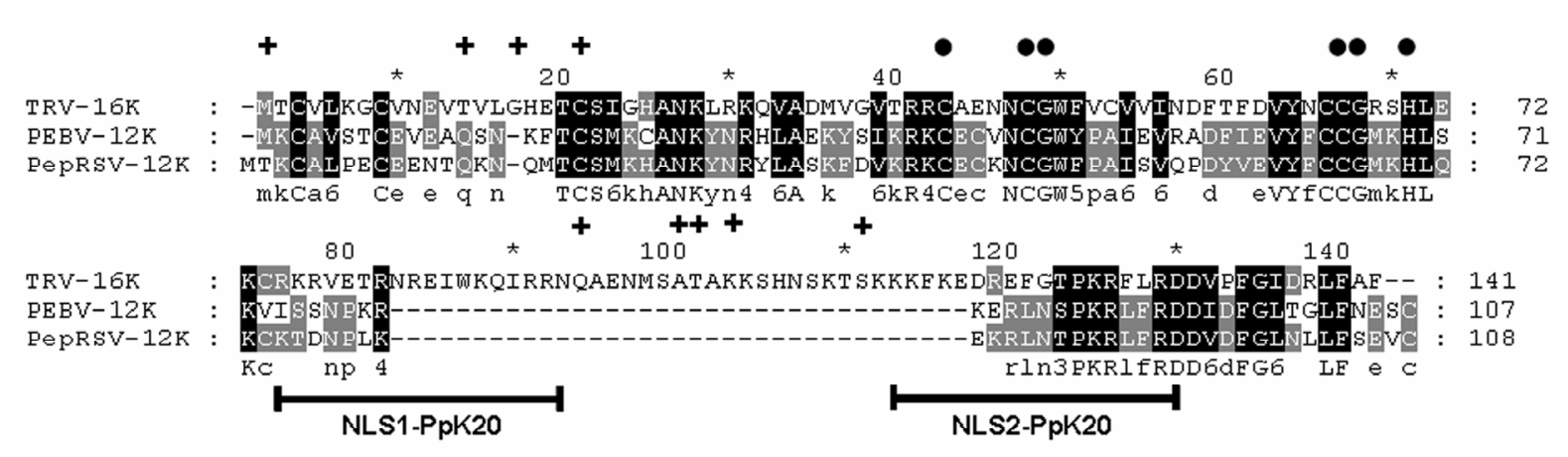

Fig. 4. ClustalX alignment of amino acid sequences of CRPs of members the genus Tobravirus. Different grades of aa conservation are reflected by shading at four levels. Two NLS in the C-terminal half identified in this study are indicated as bars. "+" display amino acid positions of 16K PpK20 PS mutants displaying tolerance (Class I and II mutants) to pentapeptide insertions in silencing suppression ability. (๑) represent 16K residues highly conserved between CRPs derived from different virus genera (Morozov et al., 1989; Savenkov et al., 1998; Diao et al., 1999; Te et al., 2005). TRV 16K-PpK20 (Acc. no. AAM50511), PEBV 12K (Acc. no. NC_002036), PepRSV 12K (Acc. no. NC_003669).

Subcellular localization of TRV 16K. Initially, we carried out a computational prediction of 16K subcellular localization using PSORT (http://www.psort.org) (Nakai \& Kanehisa, 1991). This resulted in the prediction of nuclear localization with an accuracy of 0.880 (Robbins score) and the prediction of two bipartite nuclear localization signals (NLSs) (Robbins et al., 1991) (aa positions 75-91 and 112-128) present within the C-terminal region of $16 \mathrm{~K}$ protein. To identify which of these two predicted NLSs is functional, 35S driven DsRed C-terminal fusions in binary vectors were constructed (Table 2). Construct 35S-DsRed-16K-27-41, a peptide rich in basic residues but not fitting to an NLS consensus sequence, was tested to determine whether other unrecognized NLS might be present in the protein. Constructs 35SDsRed-16K-42-51 and -16K-92-101 both represent peptides, lacking any basic residues typical of nuclear targeting domains, and therefore served as negative controls. Finally, the SV40 NLS was fused to DsRed (35S-DsRed-NLS-SV40) and used as positive control. For better cell background visualisation of both the nucleus and cytoplasm, all constructs were agroinfiltrated in transgenic $N$. benthamiana leaves (line 16c) and the intercellular localization of peptide fusions was determined at 4 dpi by CLSM (Fig. 5a). As 16c plants used in this study express GFP targeted to the endoplasmic reticulum, only the cytoplasm and the nuclear envelope of the cell were visualized, while GFP fluorescence was neither seen in 
the nucleus nor in the nucleolus (data not shown). 35S-DsRed was distributed diffusely throughout the cytoplasm and nucleus but not the nucleolus of epidermal cells, whereas 35SNLS-SV40 re-localized DsRed fluorescence exclusively into the nucleus and nucleolus, proving the suitability of the experimental approach (Fig. 5a). Compared to the two control constructs (35S-DsRed-16K-42-51 and -16K-92-101), which both did not influence the subcellular distribution of DsRed, both the computer-predicted NLSs (35S-DsRed-16K-75-91 and -112-128) were independently capable of targeting DsRed into the nucleus and nucleolus, similar to NLS-SV40. The peptide fusion 35S-DsRed-16K-27-41 did not significantly affect the DsRed distribution in $N$. benthamiana cells too, indicating that this sequence is not a functional NLS, however, a slightly increased fluorescence in the nucleus and nucleolus was detectable. Taken together, this demonstrated that the two predicted 16K NLSs were likely to be functional.

To investigate the influence of the two identified NLSs on $16 \mathrm{~K}$ subcellular localization, the complete $16 \mathrm{~K}$ ORF, N-terminal and C-terminal parts were translationally fused to $35 \mathrm{~S}-\mathrm{DsRed}$ (35S-DsRed-16K, $-16 \mathrm{~K}-\mathrm{N}$ and $-16 \mathrm{~K}-\mathrm{C}$ respectively), and used in transient agroexpression, as described above. CLSM examination (Fig. 5b) revealed that the C-terminal part mediated a nuclear localization of DsRed supporting the findings obtained with detached NLSs. In contrast, the N-terminal region unexpectedly directed the DsRed fluorescence to aggregates in the cytoplasm. Similar cytoplasmic aggregation patterns were also observed with the complete 16K ORF (35S-DsRed-16K) in most of the examined cells; however, in few cells the DsRed fluorescent was found to be directed to the nucleus too (Fig.5a, 35S-DsRed-16K [i] and [ii] respectively). DsRed-1 (Matz et al., 1999) displays obligate tetramerization (Baird et al., 2000) and has been shown by different authors to display the tendency to form intracellular aggregates (Lauf et al., 2001; Mizuno et al., 2001). To exclude the possibility that oligomerization of DsRed-1 might have an influence on subcellular distribution of our target, we cloned mRFP, a variant of DsRed known to form true monomers, under 35S-control (35S-mRFP) and subsequently fused the fragments (examined above) to the mRFP C-terminus (35S-mRFP-16K, $-16 \mathrm{~K}-\mathrm{N}$ and $-16 \mathrm{~K}-\mathrm{C}$ in analogy to the DsRed-fusions described above, Table 2). Agroinfiltration followed by CLSM analysis (Fig. 5c) showed that 35S-mRFP was uniformly distributed throughout the cell, and freely diffuses from cytoplasm to the nucleus like its parental protein DsRed-1. 35S-mRFP-16K-C was only detected in the nucleus and nucleolus comparable to the DsRed-1 fusion construct, whereas 35S-mRFP-16K-N was freely distributed in the cytoplasma. Only in few cells very 

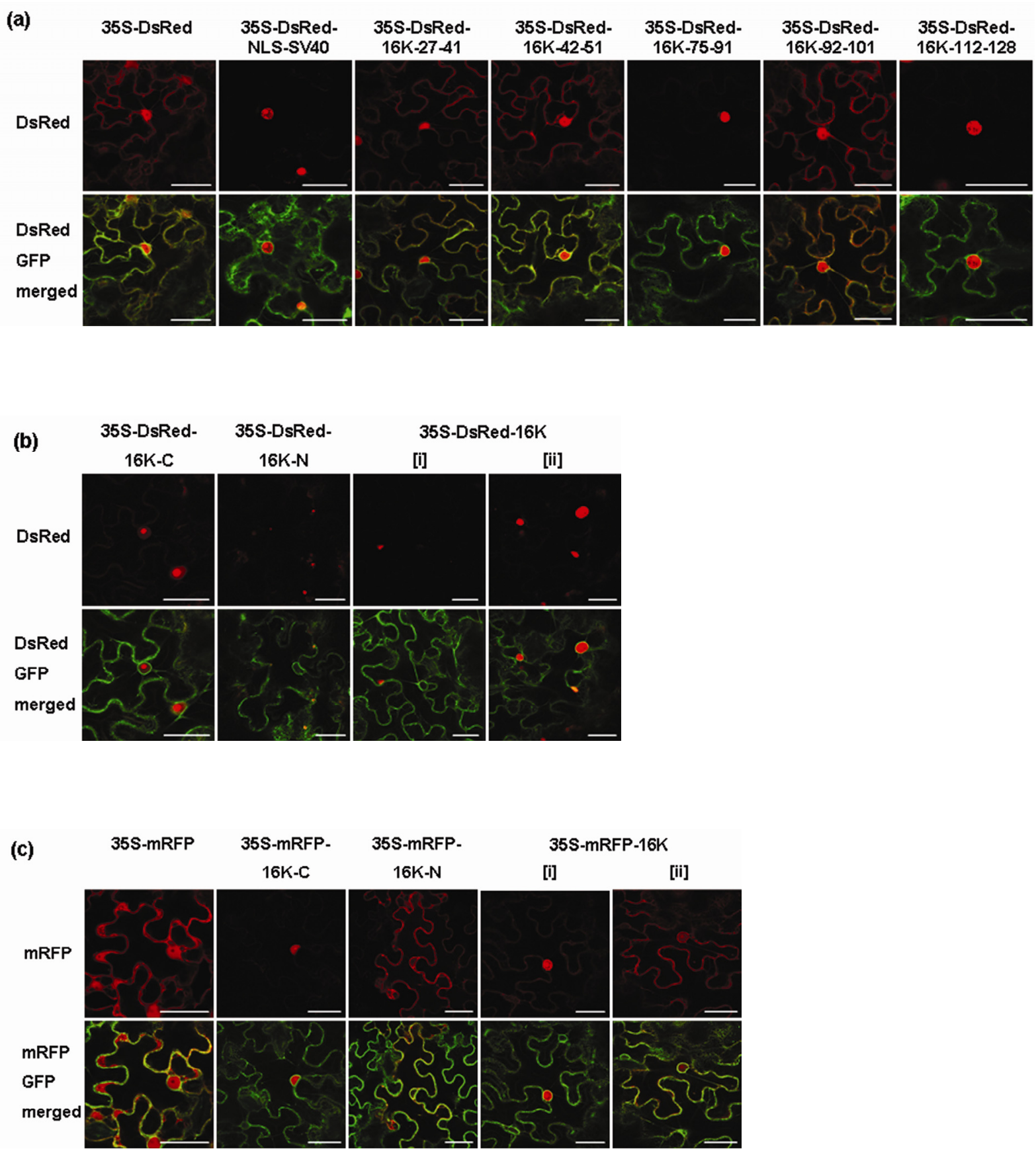

Fig. 5. Intracellular distribution of $35 \mathrm{~S}$ driven constructs displaying fusions to the C-terminus of DsRed and mRFP respectively. All constructs were transiently agroexpressed in GFP-transgenic $N$. benthamiana (line 16c) parenchyma cells and analysed under CLSM. Scale bar, $40 \mu \mathrm{m}$.

weak fluorescence was observed in the nucleus, distributed like unfused mRFP. Parenchyma cells expressing mRFP-16K varied in their fluorescence pattern. All cells displayed fluorescence in the cytoplasm but in 3/100 cells randomly counted in Epi-FM, additional strong fluorescence in the nucleus was observed (Fig. 5c, 35S-mRFP-16K [i]). 34/100 cells displayed moderate to weak nuclear fluorescence [ii]. In the remaining 63 cells, the red 
fluorescence was uniformly distributed in the cytoplasm, and excluded from the nucleus (data not shown). Combined, our data indicated that TRV 16K, in addition to the two NLSs, possesses a strong signal in the N-terminal 68 aa which may retain the fusion protein in the cytoplasm or mediate active nuclear export.

\section{Sequence comparison of $16 \mathrm{~K}$ with related CRPs and those from other tobravirus}

members. The amino acid sequence of several CRPs, possessing silencing suppression ability (BSMV and poa semilatent virus (PSLV) $\gamma \mathrm{b}$, beet necrotic yellow vein virus (BNYVV) P14, peanut clump virus (PCV) P15, soilborne wheat mosaic virus (SBWMV) 19K, PEBV and PepRSV 12K, and TRV 16K), were used for ClustalX alignment. The observed sequence homology of TRV $16 \mathrm{~K}$ to other than tobraviral CRPs was relatively low, ranging from only 8.5-10.6\% (data not shown). In contrast, CRPs from closely related tobravirus members PEBV and PepRSV 12K proteins (MacFarlane, 1999) possess sequence homology of $64.5 \%$ to each other and display $27.7 \%$ (PEBV 12K) and 31.9\% (PepRSV 12K) homology to TRV $16 \mathrm{~K}$ respectively. This is mainly caused by the smaller size of $12 \mathrm{~K}$ leading to a gap in the alignment between $16 \mathrm{~K}$ aa position $83-117$ (Fig. 5). When these additional $16 \mathrm{~K} 35$ aa are not considered in the alignment, the homology increases to 41.3 and $47.7 \%$ respectively. Since this gap is affecting both NLSs identified in 16K, additional computational prediction of nuclear localization was carried out for both $12 \mathrm{~K}$ proteins and resulted in a certainty of only 0.300 for PEBV and 0.000 for PepRSV respectively. PSORT only predicted one monopartite NLS at amino acid position 74 (PKRK) of PEBV 12K. Moreover, the first 20 aa in the N-terminal region also displayed higher sequence diversity between the two $12 \mathrm{~K}$ proteins. Interestingly, the variable $\mathrm{N}$-terminal region and the 35 aa gap in this alignment coincide with the regions in $16 \mathrm{~K}$ displaying tolerance to pentapeptide insertions.

\section{DISCUSSION}

In this study, we have found evidence that TRV 16K CRP suppresses transgene-induced RNA silencing. This finding represents the first in planta proof of function and supports previous descriptions of this protein as a virus pathogenicity factor in N. tabacum (Liu et al., 2002a). Our results on the noticeable effect of $16 \mathrm{~K}$ on the accumulation of GFP-specific siRNAs in $N$. benthamiana tissue is in contrast to previous report in Drosophila cells (Reavy 
et al., 2004), where a reduction of lacZ specific siRNAs was not found. Thus, it can be concluded that the $16 \mathrm{~K}$ suppression of gene silencing is organism specific, depending on the assay applied. It is well-known from several previous studies that CRPs from different plant RNA viruses possess only distant sequence homology relationships (Koonin et al., 1991; Savenkov et al., 1998; Diao et al., 1999; Te et al., 2005). This homology is mainly restricted to a conserved motif (Cys-Gly..Cys-Gly-X-X-His, see the tobravirus CRP alignment in Fig. 4), which is supposed to have some functional significance. It remains unknown, whether this limited degree of homology is the basis for a putative common CRP function. However, homology of the TRV $16 \mathrm{~K}$ with the $12 \mathrm{~K}$ protein of PEBV and PepRSV was much more extensive. The proteins share several short aa stretches of $100 \%$ sequence homology, indicative as well for functional homology. This suggests that these two proteins may also be silencing suppressors.

The average PS mutant density in the 141 aa $16 \mathrm{~K}$ protein at every 4.7 aa is high. Unfortunately, an unexplained gap of 25 aa in the C-terminus of the protein (between aa 110 and 135) not covered by PS mutants had to be excluded from the functional analysis. The results of the PSM study carried out with 30 independent mutants show that randomly inserted 5 aa do not significantly interfere with $16 \mathrm{~K}^{\prime}$ s stability. This is in agreement to other PSM studies (Poussu et al., 2004; Fransen et al., 2005; Varrelmann et al., 2007). The finding however that only two short aa regions tolerated the pentapeptide insertion and maintained silencing suppression is remarkable. This might indicate for dysfunction as a result of an alteration of the three-dimensional structure of the protein or due to modification of an active site. Interestingly, the sequence variability between TRV $16 \mathrm{~K}$ and the $12 \mathrm{~K}$ proteins from tobravirus PEBV and PepRSV correlate well with tolerance of $16 \mathrm{~K}$ silencing suppression to pentapeptide insertions. This provides evidence that these two parts of $16 \mathrm{~K}$ are not necessary for silencing suppression function. Previous PSM studies of proteins with known threedimensional structure (Hallet et al., 1997; Petyuk et al., 2004; Poussu et al., 2004) have shown that pentapeptide insertions in proximity to an active site of a protein or insertions that disrupt the secondary protein structure have stronger effects on protein functionality than insertions in inter-domain regions or surface loops. This makes PSM useful to identify essential regions in target proteins. The high functional sensitivity in most parts of the protein to PSM proposes strong functional and structural conservation suggesting the complete protein is required for silencing suppression. 
Without any specific targeting signal, proteins below $60 \mathrm{kDa}$, such as DsRed and mRFP, can diffuse freely through the nuclear pore complex (Görlich \& Kutay, 1999; Jach et al., 2001; Dietrich \& Maiss, 2002). Hence, we anticipated that all our constructed fusions are also small enough to diffuse passively between these two compartments. Therefore, our CLSM results demonstrate that mRFP-16K fusion protein is able to target the nucleus including the nucleolus. Furthermore, we were able to show that at least two independent bipartite NLSs (aa 75-91 and 112-128) are responsible for this effect in context of the Cterminal half of the protein as well as in the minimal consensus sequence fused to DsRed. The nucleus and nucleolus targeting effect was comparable to that induced by the SV40 monopartite NLS, demonstrating, that the nucleolar fluorescence is not a specific effect of these two bipartite signals. This is supported by other studies, demonstrating that regions rich in basic residues, lysine and arginine from other plant viral proteins are responsible for nuclear as well as nucleolar localization (Kim et al., 2004; Ryabov et al., 2004; Haupt et al., 2005). The finding that $16 \mathrm{~K}$, despite containing two NLSs, is also present in the cytoplasm is consistent to previous findings (Liu et al., 1991), but in contrast to the study of Angenent et al. (1989) who suggested organelle or membrane targeting, as the protein was found accumulated in high-molecular-weight complexes. In our study, we observed a uniform distribution of the fluorescence when the whole $16 \mathrm{~K}$ was fused to mRFP, however, we cannot exclude organelle or membrane targeting of $16 \mathrm{~K}$. Moreover, we cannot state if other TRV encoded proteins or viral replication might influence the subcellular distribution of $16 \mathrm{~K}$, as mRFP-16K was compromised in silencing suppression ability (data not shown). On the other hand, the partial exclusion of the N-terminus mRFP fusion from the nucleus and the observation that mRFP-16K nuclear targeting was incomplete, suggesting the presence of either a nuclear export signal in the N-terminus or its targeting to or retention in the cytoplasm possibly by cytoplasmic protein interaction or organelle targeting. In contrast to this but unexplained remains the observation of a nuclear fluorescent signal when the N-terminal peptide 27-41 was fused to DsRed. However additional analysis is necessary to identify the exact domain and the underlying mechanism, responsible for this nuclear exclusion. Whether the C-terminal mediated nuclear targeting or an $\mathrm{N}$-terminal driven export from the nucleus of this small protein are involved in silencing suppression can not be confirmed since both were non-functional in this respect.

The results of the sequence analysis and prediction of subcellular localization of tobravirus CRPs, showing absence of the two 16K NLSs in PepRSV and PEBV 12K due to 
the C-terminal gap in these two proteins, is remarkable. If functional homology of tobravirus CRP is assumed, it is tempting to speculate that the two bipartite NLSs of TRV 16K are dispensable for silencing suppression and belong to a secondary $16 \mathrm{~K}$ function. These $16 \mathrm{~K}$ CRP localization elements are unique among plant RNA virus CRPs. PSLV yb (Yelina et al., 2002) and PCV P15 (Dunoyer et al., 2002) CRPs are targeted to peroxisomes via a Cterminal SKL-motif shown to be dispensable for silencing suppression. This is absent in some isolates of BSMV $\gamma \mathrm{b}$ (Gustafson et al., 1987; Kozlov et al., 1989), SBWMV 19K, TRV 16K and BNYVV P14, and indicates for a functional diversity of RNA virus CRPs.

The components of the silencing machinery targeted by TRV 16K, however, remains to be determined. Comparing our TRV findings and results from previous study (Voinnet et al., 1999) with those of CRPs possessing silencing suppression ability supports functional diversity even in this group of related proteins. The observed effect of $16 \mathrm{~K}$ on the accumulation of GFP-specific siRNAs indicates for a protein activity downstream of siRNA production and possibly for an interference with the initiation step of RNA silencing. The reversion of an established RNA silencing with TRV found in earlier studies (Voinnet et al., 1999) supports our conclusion that $16 \mathrm{~K}$ suppresses the initiation and maintenance of transgene-induced RNA silencing. In contrast to this finding and supporting the functional diversity of CRPs, BSMV $\gamma \mathrm{b}$ and PCV P15 CRPs both recently have been identified to bind small dsRNA size selectively (Mérai et al., 2006). In addition, PSLV $\gamma \mathrm{b}$ CRP does not reduce siRNAs (Yelina et al., 2005) but PCV P15 does (Dunoyer et al., 2002). Another indication for a complete different mode of action of these proteins is given by the finding that (in contrast to $16 \mathrm{~K}$ ) both $\gamma \mathrm{b}$ and P15 CRPs possess a coiled-coil sequence in the C-terminal part which is responsible for dimerization and indispensable for silencing suppression (Dunoyer et al., 2002; Bragg et al., 2004). Most of the plant RNA silencing/dsRNA processing machinery seems to be cytoplasmic localized (Moissiard \& Voinnet, 2004), but there are also several indications for nuclear steps. A previous study demonstrated that Arabidopsis thaliana Dicerlike protein DCL1 processes siRNA precursors in the nucleus (Papp et al., 2003). Also, the connection between nuclear and/or nucleolar targeting of $16 \mathrm{~K}$ and its other biological functions (e.g. pathogenicity) remains unknown. Several studies have demonstrated that the nucleolar targeting of the groundnut rosette virus (GRV) ORF3 protein, and its interaction with either nucleus or nucleolus components is required for the systemic infection of the virus (Kim et al., 2004, 2007a \& b). Therefore, our results provide a valuable evidence for further investigation of the $16 \mathrm{~K}$ function in the nucleus, and to elucidate its precise mechanism(s). 


\section{ACKNOWLEDGMENTS}

TRV PpK20 full-length clone was kindly provided by S. P. Dinesh-Kumar, Yale University, New Haven, U.S.A. We are grateful to D. Silhavy, Agricultural Biotechnology Centre, Gödöllõ, Hungary, for providing plasmids pBIN61S, pBIN61S-tnos-rev and pBIN61S-gfp. We thank D. Baulcombe for kindly providing 16c GFP-transgenic N. benthamiana plants. This work was supported by the Scholarship Merit Program. Islamic Development Bank (IDB).

\section{REFERENCES}

Albrecht, H., Geldreich, A., De Murcia, J. M., Kirchherr, D., Mesnard, J. M. \& Lebeurier, G. (1988). Cauliflower mosaic virus gene I product detected in a cell-wallenriched fraction. Virology 163, 503-508.

Angenent, G. C., Verbeek, H. B. M. \& Bol, J. F. (1989). Expression of the $16 \mathrm{~K}$ cistron of Tobacco rattle virus in protoplasts. Virology 169, 305-311.

Baird, G. S., Zacharias, D. A. \& Tsien, R. Y. (2000). Biochemistry, mutagenesis, and oligomerization of DsRed, a red fluorescent protein from coral. Proc Natl Acad Sci USA 97, 11984-11989.

Bass, B. L. (2000). Double-stranded RNA as a template for gene silencing. Cell 101, 235238.

Baulcombe, D. C. (2004). RNA silencing in plants. Nature 431, 356-363.

Bernstein, E., Caudy, A. A., Hammond, S. \& Hannon, G. J. (2001). Role for a bidentate ribonuclease in the initiation step of RNA interference. Nature 409, 363-366.

Bragg, J. N. \& Jackson, A. O. (2004). The C-terminal region of the Barley stripe mosaic virus $\gamma \mathrm{b}$ protein participates in homologous interactions and is required for suppression of RNA silencing. Mol Plant Pathol 5, 465-481.

Bragg, J. N., Lawrence, D. M. \& Jackson, A. O. (2004). The N-terminal 85 amino acids of the Barley stripe mosaic virus $\gamma \mathrm{b}$ pathogenesis protein contain three zinc binding motifs. $J$ Virol 78, 7379-7391. 
Brigneti, G., Voinnet, O., Li, W. -X., Ji, L. -H., Ding, S. -W. \& Baulcombe, D. C. (1998). Viral pathogenicity determinants are suppressors of transgene silencing in Nicotiana benthamiana. EMBO J 17, 6739-6746.

Campbell, R. E., Tour, O., Palmer, A. E., Steinbach, P. A., Baird, G. S., Zacharias, D. A. \& Tsien, R. Y. (2002). A monomeric ref fluorescent protein. Proc Natl Acad Sci USA 99, $7877-7882$.

Diao, A., Chen, J., Ye, R., Zheng, T., Yu, S., Antoniw, J. F. \& Adams, M. J. (1999). Complete sequence and genome properties of Chinese wheat mosaic virus, a new Furovirus from China. J Gen Virol 80, 1141-1145.

Dietrich, C. \& Maiss, E. (2002). Red fluorescent protein DsRed from Discosoma sp. as a reporter protein in higher plants. Biotechniques 32, 286-293.

Donald, R. G. K. \& Jackson, A. O. (1994). The Barley stripe mosaic virus $\gamma \mathrm{b}$ gene encodes a multifunctional cysteine-rich protein that affects pathogenesis. Plant Cell 6, 1593-1606.

Dunoyer, P., Pfeffer, S., Fritsch, C., Hemmer, O., Voinnet, O. \& Richards, K. E. (2002). Identification, subcellular localization and some properties of a cysteine-rich suppressor of gene silencing encoded by Peanut clump virus. Plant J 29, 555-567.

Edwards, M. C. (1995). Mapping of the seed transmission determinants of Barley stripe mosaic virus. Mol Plant Microbe Interact 8, 906-915.

Elbashir, S. M., Lendeckel, W. \& Tuschl, T. (2001). RNA interference is mediated by 21and 22-nucleotide RNAs. Genes Dev 15, 188-200.

Fransen, M., Vastiau, I., Brees, C., Brys, V., Mannaerts, G. P. \& Van Veldhoven, P. P. (2005). Analysis of human Pex19p's domain structure by pentapeptide scanning mutagenesis. J Mol Biol 346, 1275-1286.

Görlich, D. \& Kutay, U. (1999). Transport between the cell nucleus and the cytoplasm. Annu Rev Cell Dev Biol 15, 607-660.

Gustafson, G., Hunter, B., Hanau, R., Armour, S. L. \& Jackson, A. O. (1987). Nucleotide sequence and genetic organization of Barley stripe mosaic virus RNA $\beta$. Virology 158, 384 406. 
Haapa, S., Taira, S., Heikkinen, E. \& Savilahti, H. (1999). An efficient and accurate integration of mini-Mu transposons in vitro: a general methodology for functional genetic analysis and molecular biology applications. Nucleic Acids Res 27, 2777-2784.

Hallet, B., Sherratt, D. J. \& Hayes, F. (1997). Pentapeptide scanning mutagenesis: random insertion of a variable five amino acid cassette in a target protein. Nucleic Acids Res 25, $1866-1867$.

Hamilton, A. J. \& Baulcombe, D. C. (1999). A species of small antisense RNA in posttranscriptional gene silencing in plants. Science 286, 950-952.

Hammond, S. M., Bernstein, E., Beach, D. \& Hannon, G. J. (2000). An RNA-directed nuclease mediates post-transcriptional gene silencing in Drosophila cells. Nature 404, 293296.

Haseloff, J., Siemering, K. R., Prasher, D. C. \& Hodge, S. (1997). Removal of a cryptic intron and subcellular localization of green fluorescent protein are required to mark transgenic Arabidopsis plants brightly. Proc Natl Acad Sci USA 94, 2122-2127.

Haupt, S., Cowan, G. H., Ziegler, A., Roberts, A. G., Oparka, K. J. \& Torrance, L. (2005). Two plant-viral movement proteins traffic in the endocytic recycling pathway. Plant Cell 17, 164-181.

Hayes, F. (2003). Transposon-based strategies for microbial functional genomics and proteomics. Annu Rev Genet 37, 3-29.

Himber, C., Dunoyer, P., Moissiard, G., Ritzenthaler, C. \& Voinnet, O. (2003). Transitivity-dependent and -independent cell-to-cell movement of RNA silencing. EMBO J 22, 4523-4533.

Jach, G., Binot, E., Frings, S., Luxa, K. \& Schell, J. (2001). Use of red fluorescent protein from Discosoma sp. (dsRED) as a reporter for plant gene expression. Plant J 28, 483-491.

Kalderon, D., Roberts, B. L., Richardson, W. D. \& Smith, A. E. (1984). A short amino acid sequence able to specify nuclear location. Cell 39, 499-509.

Kim, S. H., Ryabov, E. V., Brown, J. W. S. \& Taliansky, M. (2004). Involvement of the nucleolus in plant virus systemic infection. Bioch Soc Trans 32, 557-560. 
Kim, S. H., Ryabov, E. V., Kalinina, N. O., Rakitina, D. V., Gillespie, T., MacFarlane, S., Haupt, S., , Brown, J. W. S. \& Taliansky, M. (2007a). Cajal bodies and the nucleolus are required for a plant virus systemic infection. EMBO J 26, 2169-2179.

Kim, S. H., MacFarlane, S., Kalinina, N. O., Rakitina, D. V., Ryabov, E. V., Gillespie, T., Haupt, S., Brown, J. W. S. \& Taliansky, M. (2007b). Interaction of a plant virusencoded protein with the major nucleolar protein fibrillarin is required for systemic virus infection. Proc Natl Acad Sci USA 104, 11115-11120.

Klahre, U., Crété, P., Leuenberger, S. A., Iglesias, V. A. \& Jr., F. M. (2002). High molecular weight RNAs and small interfering RNAs induce systemic posttranscriptional gene silencing in plants. Proc Natl Acad Sci USA 99, 11981-11986.

Koonin, E. V., Boyko, V. P. \& Dolja, V. V. (1991). Small cysteine-rich proteins of different groups of plant RNA viruses are related to different families of nucleic acid-binding proteins. Virology 181, 395-398.

Kozlov, Iu. V., Afanas'ev, B. N., Rupasov, V. V., Golova, Iu. B., Kulaeva, O. I., Dolia, V. V., Atabekov, J. G. \& Baev, A. A. (1989). Primary structure of RNA 3 of Barley stripe mosaic virus and its variability. Mol Biol 23, 1080-1090.

Lakatos, L., Csorba, T., Pantaleo, V., Chapman, E. J., Carrington, J. C., Liu, Y. -P., Dolja, V. V., Calvino, L. F., López-Moya, J. J. \& Burgyán, J. (2006). Small RNA binding is a common strategy to suppress RNA silencing by several viral suppressors. EMBO $J \mathbf{2 5}$, $2768-2780$.

Lauf, U., Lopez, P. \& Falk, M. M. (2001). Expression of fluorescently tagged connexins: a novel approach to rescue function of oligomeric DsRed-tagged proteins. FEBS letters 498, $11-15$.

Li, F. \& Ding, S.-W. (2006). Virus counterdefense: diverse strategies for evading the RNAsilencing immunity. Annu Rev Microbiol 60, 503-531.

Liu, D. H., Robinson, D. J., Duncan, G. H. \& Harrison, B. D. (1991). Nuclear location of the 16K non-structural protein of Tobacco rattle virus. J Gen Virol 72, 1811-1817.

Liu, H., Reavy, B., Swanson, M. \& MacFarlane, S. A. (2002a). Functional replacement of the Tobacco rattle virus cysteine-rich protein by pathogenicity proteins from unrelated plant viruses. Virology 298, 232-239. 
Liu, Y., Schiff, M., Marathe, R. \& Dinesh-Kumar, S. P. (2002b). Tobacco Rar1, EDS1 and NPR1/NIM1 like genes are required for $N$-mediated resistance to Tabacco mosaic virus. Plant J 30, 415-429.

MacFarlane, S. A. (1999). Molecular biology of the Tobraviruses. J Gen Virol 80, 27992807.

MacFarlane, S. A., Taylor, S. C., King, D. I., Hughes, G. \& Davies, J. W. (1989). Pea early browning virus RNA1 encodes four polypeptides including a putative zinc-finger protein. Nucleic Acids Res 17, 2245-2260.

Matz, M. V., Fradkov, A. F., Labas, Y. A., Savitsky, A. P., Zaraisky, A. G., Markelov, M. L. \& Lukyanov, S. A. (1999). Fluorescent proteins from nonbioluminescent Anthozoa species. Nature Biotechnol 17, 969-973.

Mérai, Z., Kerényi, Z., Kertész, S., Magna, M., Lakatos, L. \& Silhavy, D. (2006). Double-stranded RNA binding may be a general plant RNA viral strategy to suppress RNA silencing. $J$ Virol 80, 5747-5756.

Mizuno, H., Sawano, A., Eli, P., Hama, H. \& Miyawaki, A. (2001). Red fluorescent protein from Discosoma as a fusion tag and a partner for fluorescence resonance energy transfer. Biochemstry 40, 2502-2510.

Mlotshwa, S., Voinnet, O., Mette, M. F., Matzke, M., Vaucheret, H., Ding, S. W., Pruss, G. \& Vance, V. B. (2002). RNA silencing and the mobile silencing signal. Plant Cell 14 (Suppl.), S289-S301.

Moissiard, G. \& Voinnet, O. (2004). Viral suppression of RNA silencing in plants. Mol Plant Pathol 5, 71-82.

Morozov, S. Yu., Dolja, V. V. \& Atabekov, J. G. (1989). Probable reassortment of genomic elements among elongated RNA-containing plant viruses. J Mol Evol 29, 52-62.

Nakai, K. \& Kanehisa, M. (1991). Expert system for predicting protein localization sites in gram-negative bacteria. Proteins 11, 95-110.

Palauqui, J. -C., Elmayan, T., Pollien, J. -M. \& Vaucheret, H. (1997). Systemic acquired silencing: transgene-specific post-transcriptional silencing is transmitted by grafting from silenced stocks to non-silenced scions. EMBO J 16, 4738-4745. 
Papp, I., Mette, M. F., Aufsatz, W., Daxinger, L., Schauer, S. E., Ray, A., van der Winden, J., Matzke, M. \& Matzke, A. J. M. (2003). Evidence for nuclear processing of plant micro RNA and short interfering RNA precursors. Plant Physiol 132, 1382-1390.

Petyuk, V., McDermott, J., Cook, M. \& Sauer, B. (2004). Functional mapping of Cre Recombinase by pentapeptide insertional mutagenesis. J Biol Chem 279, 37040-37048.

Poussu, E., Vihinen, M., Paulin, L. \& Savilahti, H. (2004). Probing the alphacomplementing domain of $E$. coli beta-galactosidase with use of an insertional pentapeptide mutagenesis strategy based on Mu in vitro DNA transposition. Proteins 54, 681-692.

Reavy, B., Dawson, S., Canto, T. \& MacFarlane, S. A. (2004). Heterologous expression of plant virus genes that suppress post-transcriptional gene silencing results in suppression of RNA interference in Drosophila cells. BMC Biotechnol 4, 18.

Robbins, J., Dilworth, S. M., Laskey, R. A. \& Dingwall, C. (1991). Two interdependent basic domains in nucleoplasmin nuclear targeting sequence: identification of a class of bipartite nuclear targeting sequence. Cell 64, 615-623.

Ryabov, E. V., Kim, S. H. \& Taliansky, M. (2004). Identification of a nuclear localization signal and nuclear export signal of the umbraviral long-distance RNA movement protein. $J$ Gen Virol 85, 1329-1333.

Sambrook, J., Fritsch, E. F. \& Maniatis, T. (1989). Molecular cloning: a laboratory manual. 2nd edn. New York: Cold Spring Harbor.

Savenkov, E. I., Solovyev, A. G. \& Morozov, S. Yu. (1998). Genome sequences of Poa semilatent and Lychnis ringspot Hordeiviruses. Arch Virol 143, 1379-1393.

Silhavy, D. \& Burgyán, J. (2004). Effects and side-effects of viral RNA silencing suppressors on short RNAs. Trends Plant Sci 9, 76-83.

Silhavy, D., Molnár, A., Licioli, A., Szittya, G., Hornyik, C., Tavazza, M. \& Burgyán, J. (2002). A viral protein suppresses RNA silencing and binds silencing-generated, 21- to 25nucleotide double-stranded RNAs. EMBO J 21, 3070-3080.

Taylor, C. E. \& Brown, D. J. F. (1997). Nematode Vectors of Plant Viruses. New York: CAB International. 
Te, J., Melcher, U., Howard, A. \& Verchot-Lubicz, J. (2005). Soilborne wheat mosaic virus (SBWMV) 19K protein belongs to a class of cysteine-rich proteins that suppress RNA silencing. Virology $J \mathbf{2}, 18$.

Thompson, J. D., Gibson, T. J., Plewniak, F., Jeanmougin, F. \& Higgins, D. G. (1997). The CLUSTAL_X windows interface: flexible strategies for multiple sequence alignment aided by quality analysis tools. Nucleic Acids Res 25, 4876-4882.

Towbin, H., Staehelin, T. \& Gordon, J. (1979). Electrophoretic transfer of proteins from polyacrylamide gels to nitrocellulose sheets: Procedure and some applications. Proc Natl Acad Sci USA 76, 4350-4354.

Varrelmann, M., Maiss, E., Pilot, R. \& Palkovics, L. (2007). Use of pentapeptide insertion scanning mutagenesis for functional mapping of Plum pox virus helper component proteinase suppressor of gene silencing. J Gen Virol 88, 1005-1015.

Voinnet, O. (2001). RNA silencing as a plant immune system against viruses. Trends Genet 17, 449-459.

Voinnet, O. (2005). Induction and suppression of RNA silencing: insights from viral infections. Nature Rev Genet 6, 206-220.

Voinnet, O. \& Baulcombe, D. C. (1997). Systemic signalling in gene silencing. Nature 389, 553.

Voinnet, O., Pinto, Y. M. \& Baulcombe, D. C. (1999). Suppression of gene silencing: A general strategy used by diverse DNA and RNA viruses of plants. Proc Natl Acad Sci USA 96, 14147-14152.

Voinnet, O., Lederer, C. \& Baulcombe, D. C. (2000). A viral movement protein prevents spread of the gene silencing signal in Nicotiana benthamiana. Cell 103,157-167.

Wang, D., MacFarlane, S. A. \& Maule, A. J. (1997). Viral determinants of Pea early browning virus seed transmission in pea. Virology 234, 112-117.

Yelina, N. E., Savenkov, E. I., Solovyev, A. G., Morozov, S. Y. \& Valkonen, J. P. T. (2002). Long-distance movement, virulence, and RNA silencing suppression controlled by a single protein in Hordei- and Potyviruses: complementary functions between virus families. $J$ Virol 76, 12981-12991. 
Yelina, N. E., Erokhina, T. N., Lokhovitskaya, N. I., Minina, E. A., Schepetilnikov, M. V., Lesemann, D. -E., Schiemann, J., Solovyev, A. G. \& Morozov, S. Y. (2005). Localization of Poa semilatent virus cysteine-rich protein in peroxisomes is dispensable for its ability to suppress RNA silencing. J Gen Virol 86, 479-489.

Ziegler-Graff, V., Guilford, P. J. \& Baulcombe, D. C. (1991). Tobacco rattle virus RNA-1 $29 \mathrm{~K}$ gene product potentiates viral movement and also affects symptom induction in tobacco. Virology 182, 145-155. 


\section{CHAPTER 4}

\section{General Discussion}

Virus-resistance responses in potato have been extensively characterized during the last decade for many different viruses (reviewed by Solomon-Blackburn and Barker 2001). However, clear reports on resistance types against TRV in potato are still missing. This is due to the fact that screening for resistance to spraing in potato is based only on exposure to nematode infection in naturally infested soils, since TRV infection in the field requires the transmission of the virus by its vector. This kind of screening is slow and laborious and often yields varying results due to the inconsistent conditions. Therefore, unlike most of other potato viruses, assessments of the sensitivity of potato cultivars against TRV infection have mainly been based on scoring spraing symptoms in progeny tubers resulting from plants grown in naturally infected soils or in the greenhouse in pots with tested soil-inhabiting viruliferous trichodorid nematodes (Dale and Solomon 1988; Harrison 1968). Nevertheless, none of these studies characterizes the types of resistance reactions to TRV induced upon manual leaf-inoculation in relation to the standard classification and nomenclature of resistance types known (Cooper and Jones 1983; Hull 2002; Valkonen et al. 1996). Moreover, it is not known whether the resistance reaction of potato tubers by nematode infection correlates with resistance to mechanical inoculation. Therefore, we aimed to study the host reaction of three potato cultivars, with a well-known reaction against natural nematode infection with TRV-PpK20, to mechanical and Agrobacterium-mediated leaf inoculation with TRV-DsRed. This DsRed expressing TRV cDNA clone enabled us to detect the virus replication in initially inoculated cells and to monitor its movement to noninoculated tissue. In order to maintain a high suitability of this system, we had first to ascertain any possible interfering of the agrobacteria or toxicity of DsRed with the host reaction in potato leaves. The use of an agrobacteria suspension with a density of $3.2 \times 10^{4}$ in all infiltration experiments (which does not induce any host reaction when the empty binary vector is used), and the detection of DsRed fluorescent in all three potato cultivars agroinfiltrated with 35S-DsRed ruled out the effect of these two factors. Moreover, since several studies have shown that host reaction in potato to virus infection may be temperaturedependent or influenced by environmental conditions (Adams et al. 1986; Valkonen 1997), 
maintaining all inoculated potato plants at a constant temperature $\left(20-22^{\circ} \mathrm{C}\right)$ excluded such influence.

Mechanical leaf-inoculation of potato cultivars with TRV-DsRed revealed three distinct host reactions: 'spreading necrosis', HR-like, and ER in cvs. 'Russett Burbank', 'Bintje', and 'Saturna' respectively, suggesting that spraing and resistance to spraing is not determined by factors of the virus vector. These obtained reactions fit nicely into the classical categories of incompatible host resistance response in potato to virus infection. Several reports have stated that ER and HR are the most common reactions observed in virusresistance interactions in potato, and are found to be inherited monogenically (Kang et al. 2005; Valkonen et al. 1996). Recently, Barker and Dale (2006) reported that resistance to TRV appears to be controlled by a single resistance gene in some potato genotypes. The FM analysis of RNA-2 expressing DsRed and the TRV RT-PCR detection in inoculated leaves revealed that the HR-like in cv. 'Bintje' resembled the HR to PVX conferred by the $N b$ and $N x$ genes in potato (Cockerham 1970) and HR against several potyviruses (Valkonen 1997). The ER in cv. 'Saturna' strongly resembled the ER observed in potato carrying the monogenic dominant resistance against PVX $(R x 1$ and $R x 2)$ (Köhm et al. 1993; Ritter et al. 1991). Host reactions upon leaf agroinfiltration of same cultivars with TRV-DsRed were identical to mechanical inoculation, except that a cell death was developed in the ER cv. 'Saturna'. This domenstrates that the TRV resistance in this cultivar possesses the potential to induce secondary HR instead of ER. This is in agreement with the constitutive expression of the PVX CP, the elicitor of ER Rxl-mediated resistance in potato (Bendahmane et al. 1999).

Co-infiltration of TRV RNA-1 deletion mutants (TRV- $\Delta 16 \mathrm{~K}-\mathrm{DsRed}$ and $-\Delta 29 \mathrm{~K}$ DsRed) together with pTRV2-DsRed helped in understanding the possible underlying pathogen recognition mechanism. The findings that $29 \mathrm{~K}$ deletion, and not $16 \mathrm{~K}$ deletion, did not induce necrotic reaction in cvs. 'Bintje' and 'Saturna' concluded that the $29 \mathrm{~K}$ is the avirulence gene product in both host pathogen interactions. Subsequently, Agrobacteriumtransient expression as well as PVX-mediated expression assays demonstrated that the $29 \mathrm{~K}$ gene of TRV-PpK20 is the elicitor of resistance in both the HR-like and ER potato cultivars, and its activity requires no other TRV encoded proteins or RNA replication. RT-PCR analysis revealed that the protein, and not the mRNA, is the inducer of this resistance. However, two points should be taken into consideration. First, we cannot ignore other factors that are necessary for the $29 \mathrm{~K}$ elicitor function. Second, despite the fact that the involvement of the $16 \mathrm{~K}$ suppressor of RNA silencing in HR-like induction has been ruled out, the role of 
silencing in strength and speed of the host reaction still needs to be investigated, since both the plant host resistance and the RNA silencing pathways has been previously suggested to be more or less linked together (Soosaar et al. 2005; Voinnet 2005).

The use of selected potato cultivars with well-known reactions to spraing by natural nematode infection allowed us to search for a correlation between the resistance to spraing by natural nematode infection and the host resistance type(s) induced upon leaf-inoculation with TRV. 'Russet Burbank' is considered as a susceptible spraing cultivar (Harrison 1968; Mojtahedi et al. 2001). Both 'Bintje' and 'Saturna' cultivars were found to be resistant to TRV PpK20 nematode infection (Robinson et al. 2004). Robinson (2004) has reported the occurrence of an isolate of TRV (PpO85M) able to overcome the spraing resistance in cv. 'Bintje' but not in cv. 'Saturna' by means of nematode infection. It is important to mention here that, up to this point, there is no experimental evidence on the mechanism of how spraing is induced in tubers of infected plants. Initial studies on resistance assessment to spraing symptoms found that leaves of resistant cultivars are susceptible to manual inoculation, although no correlation to resistance to spraing in the tubers could be observed (Harrison 1968; Harrison and Cooper 1974). However, our results of constitutive expression of $29 \mathrm{~K}$ of either PpK20 or PpO85M isolate are in contrast to Robinson's spraing observations, concluding that resistance to spraing may require the recognition of the avirulence gene product. To prove this hypothesis, it would be necessary to construct PpK20 and PpO85M 29K-chimeras and apply them in nematode infection experiments.

With our basis on the 'gene-for-gene' model, we assumed that in the susceptible cv. Russet Burbank no recognition of resistance would occur. In our study, both RT-PCR test and FM analysis of mechanically inoculated and non-inoculated 'Russet Burbank' leaves with TRV-DsRed suggested that the spreading necrosis is likely to be a hypersensitive-like host reaction, where this kind of resistance is inable to stop the virus spread. Moreover, analysis of pTRV1 deletion mutants presented a strong indication that the spreading necrosis might be induced by the moving virus, probably as ribonucleoprotein (virus RNA in association with $29 \mathrm{~K}$ ); however, experimental proof is missing. Both PpK20 and PpO85M isolates accumulated in inoculated leaves of the susceptible and HR cvs. 'Russet Burbank' and 'Bintje', respectively. On the other hand, only PpO85M isolate was found to be accumulated in inoculated leaves of the ER cv. 'Saturna', although the virus could not establish a systemic infection in any of the three cultivars. In comparison, both the avirulent and the resistancebreaking isolates of PVX were accumulated in the susceptible and HR $(N x)$ potato cultivars, 
while only in the ER $(R x l)$ cultivar was the breaking-resistance isolate accumulated along with the establishment of a systemic infection (Kavanagh $\boldsymbol{e t}$ al. 1992). However, in contrast to our expectations, PpO85M did not establish a systemic infection in any of the three cultivars. It is known that resistance-breaking isolates are less fit than those of the wild type (Harrison 2002). Also, it cannot be anticipated if the inability to establish a systemic infection is due to the low accumulation of RNA or other reasons. This would be well worth studying further in future research. On the other hand, the mechanical inoculation of TRVPpK20 and $-\mathrm{PpO} 85 \mathrm{M}$ isolates in cv. 'Saturna' revealed isolate-specific ER and HR-like respectively, which is the first report of such type of resistance in potato. This finding, in addition to the identification of a single virus avr-gene, suggests monogenic dominant inheritance mediated by one single or two different resistance genes.

Agroexpression of 35S-29K-PpO85M did not induce cell death in cv. 'Bintje', but it did in cv. 'Saturna'. Both sequence alignment and phylogenetic tree analysis showed that the sequence of $29 \mathrm{~K}-\mathrm{PpO} 85 \mathrm{M}$ is highly divergent compared to $29 \mathrm{~K}$ genes from other isolates, with the existence of 10 variable amino acids between the $29 \mathrm{~K}-\mathrm{PpK} 20$ and -PpO85M. This difference in sequence between the avirulent and the resistance-breaking isolates have been reported for PVX isolates (Kavanagh et al. 1992). However, in our sequence results, none of these 10 changes can be attributed yet to the biological effects observed. Therefore, we cannot state whether it is only a domain or the entire protein that is necessary for triggering the host resistance response. Analysis of the different 29K-PpK20 mutants (e.g., frameshift mutation) will allow the identifying of which nucleotide change(s) is/are involved in the resistance-breaking phenotype. Altogether, these results show that agroexpression of the elicitor of the resistance is an excellent tool to screen crossing populations, as it gives much faster and more reliable information about the susceptibility of breeding lines against TRV infection than the resistance assessment in the field in natural infested soils. Applying such a system will also give the opportunity to investigate whether the resistance is elicited by $29 \mathrm{~K}$ proteins derived from other known TRV isolates.

We aimed to characterize the silencing suppression activity of TRV-16K-PpK20 in planta, and to investigate its participation in the virus life cycle and subcellular localization. In our initial sequence comparison (not shown in this study) at the amino acid level of $16 \mathrm{~K}$ with other plant viral CRPs, including those possessing a suppression of RNA silencing activity, we observed only limited sequence homology $(8.5-10.6 \%)$. This is consistent with previous studies which showed that CRPs, in general, display only limit sequence homology 
(Diao et al. 1999; Koonin et al. 1991, Savenkov et al. 1998, Te et al. 2005). However, our sequence comparison between $16 \mathrm{~K}$ and $12 \mathrm{~K}$ from closely related tobravirus members (PEBV and PepRSV) revealed a higher considerable homology sequence (27.7\% and 31.9\% respectively), indicating for a functional homology between CRPs of this genus. Having this sequence analysis data on our hands allowed us to obtain several important conclusions on the motifs involved in suppression of RNA silencing activity and subcellular localization of $16 \mathrm{~K}$, and to make a comparison with other tobravirus CRPs.

The TRV RNA-1 encoded 16K CRP has previously been shown to function as a pathogenicity determinant in tobacco (Liu et al. 2002). Several plant viral CRPs which are involved in pathogenicity are also found to possess suppression of RNA silencing activity (Brigneti et al. 1998; Li et al. 1999; Voinnet et al. 1999). TRV-16K was found to possess such activity as well; however, it was only investigated in Drosophila cells and revealed in partial suppression of RNA silencing, and no reduction in the LacZ specific siRNA was observed (Reavy et al. 2004). In the present study, we have demonstrated that the TRV 16K CRP suppresses transgene-induced gene silencing in the Agrobacterium-transient suppression assay in GFP-transgenic $N$. benthamiana plants: a first in planta proof of function. The protein efficiently prevented GFP mRNA degradation, and significantly reduced the accumulation of GFP specific siRNA in agroinfiltrated leaf-patches. This inconsistency in suppression activity of $16 \mathrm{~K}$ obtained in our study, in comparison with that obtained from the Drosophila system, led to the conclusion that the $16 \mathrm{~K}$ ability to suppress silencing is somehow organism specific, depending on the assay applied.

In order to analyze the specific domains involved in silencing suppression, we produced a library of random pentapeptide 5 aa insertions in the TRV PpK20 16K gene using PSM. This mutagenesis approach has recently been proved useful in identifying essential functional regions in the helper component proteinase, the suppressor of the gene silencing protein of Plum pox virus (PPV), without having any effect on the protein's stability (Varrelmann 2007). Analysis of PS mutants in transient suppression assay showed that two short regions (aa 13-20 and aa 93-110 respectively) tolerated the 5 aa insertion and maintained silencing suppression activity. These two regions coincide with sequence variability between tobravirus CRPs, suggesting a strong functional and possibly structural conservation of TRV 16K. From the other side, this also provides strong evidence that these two parts of $16 \mathrm{~K}$ are not necessary for the silencing suppression function. However, analysis of plants infected with TRV RNA-1 hybrids, replacing the 16K ORF with the PS mutants 
produced, will help in understanding the functional domains in the biological functions of the protein.

Agrobacteruim-mediated transient expression of several peptides fused to the DsRed led to the identification of two bipartite NLSs located in the C-terminus half of the protein. This has been supported by the localization of C-terminus predominantly into the nucleus when fused to either DsRed or mRFP. This is the first report for a suppressor CRP containing NLS among all plant viral suppressor CRPs identified until today. In contrast, the $16 \mathrm{~K}-\mathrm{N}-$ terminal fusion targeted the DsRed or mRFP fluorescence predominantly to the cytoplasm. This suggested that $16 \mathrm{~K}$ may possess either a nuclear export or cytoplasmic retention signal located in the N-terminus half. However, additional analysis is necessary to identify the exact domain and the underlying mechanism responsible for this effect. Our findings that $16 \mathrm{~K}$ protein targets the nucleus, as well as, present in the cytoplasm is consistent with previous study (Liu et al. 1991), who detect the 16K in both the cytoplasm and the nucleus of ultrathin sections of TRV infected tissue in immunogold detection. In contrast, another study found the protein only in the cytoplasmic fraction, accumulated in high-molecular-weight complexes. The study suggested for organelle or membrane targeting (Angenent et al. 1989). In this regard, for example, the $\gamma \mathrm{b}$ and P15 CRPs of PSLV and PCV respectively both are targeting the peroxisome; nevertheless, this kind of targeting has been found to be dispensable for silencing suppression (Dunoyer et al. 2002; Yelina et al. 2005). In our study, we observed a uniform distribution of the fluorescence when the whole $16 \mathrm{~K}$ was fused to mRFP, however, we cannot exclude organelle or membrane targeting of $16 \mathrm{~K}$. Moreover we cannot state if other TRV encoded proteins or viral replication might influence the subcellular distribution of $16 \mathrm{~K}$. Whether C-terminal mediated nuclear targeting or N-terminal driven export from the nucleus of this small protein are involved in silencing suppression function remains speculative. However, the functional homology of tobravirus CRPs concluded from the sequence analysis allowed us at least to speculate that the two NLSs identified in $16 \mathrm{~K}$ are dispensable for silencing suppression and belong to a secondary $16 \mathrm{~K}$ function; since these NLSs are absent in the $12 \mathrm{~K}$ from closely related tobravirus members, PEBV and PepRSV.

The mode of action of relatively few plant suppressor CRPs was determined. For example, both $\gamma b$ and P15 CRPs are binding siRNA (Mérai et al. 2006); however, their effects on the siRNA accumulation are different (Dunoyer et al. 2002; Yelina et al. 2005). Also, both possess a coiled-coil sequence, which is absent in $16 \mathrm{~K}$, and this sequence found to be indispensable for their silencing suppression activity (Bragg and Jackson 2004; Dunoyer 
et al. 2002). The identification of two NLSs in $16 \mathrm{~K}$ suggested a nuclear role of this protein. To know whether $16 \mathrm{~K}$ is targeted to the nucleus and affects nuclear steps of silencing would require further investigation. On the other hand, TRV was found previously to reverse RNA silencing in the silencing reversal assay (Voinnet et al. 1999). Alongside previous studies with our finding that $16 \mathrm{~K}$ reduces the accumulation of GFP specific siRNA indicates that the protein may act downstream of siRNA production and this suggests that $16 \mathrm{~K}$ may interfere with the initiation and/or maintenance of RNA silencing.

\section{REFERENCES}

Adams, S. E., R. A. C. Jones, and R. H. A. Coutts. 1986. Effect of temperature on Potato virus $X$ infection in potato cultivars carrying different combinations of hypersensitivity genes. Plant Pathol. 35:517-526.

Barker, H., and M. F. B. Dale. 2006. Resistance to viruses in potato. Pages 341-366 in: Natural Resistance Mechanisms of Plants to Viruses. G. Loebenstein, and J. P. Carr, eds. Springer, The Netherlands.

Bendahmane, A., K. Kanyuka, and D. C. Baulcombe. 1999. The $R x$ gene from potato controls separate virus resistance and cell death responses. Plant Cell 11:781-791.

Bragg, J. N., and A. O. Jackson. 2004. The C-terminal region of the Barley stripe mosaic virus $\gamma \mathrm{b}$ protein participates in homologous interactions and is required for suppression of RNA silencing. Mol. Plant Pathol. 5:465-481.

Brigneti, G., O. Voinnet, W. X. Li, L. H. Ji, S. W. Ding, and D. C. Baulcombe. 1998. Viral pathogenicity determinants are suppressors of transgene silencing in Nicotiana benthamiana. EMBO J. 17:6739-6746.

Cockerham, G. 1970. Genetical studies on resistance to Potato viruses $X$ and $Y$. Heredity 25:309-348.

Cooper, J. I., and A. T. Jones. 1983. Responses of plants to viruses: proposals for the use of terms. Phytopathol. 73:127-128.

Dale, M. F. B., and R. M. Solomon. 1988. A glasshouse test to assess the sensitivity of cultivars to Tobacco rattle virus. Ann. Appl. Biol. 112:225-229. 
Diao, A., J. Chen, R. Ye, T. Zheng, S. Yu, J. F. Antoniw, and M. J. Adams. 1999. Complete sequence and genome properties of Chinese wheat mosaic virus, a new Furovirus from China. J. Gen. Virol. 80:1141-1145.

Dunoyer, P., S. Pfeffer, C. Fritsch, O. Hemmer, O. Voinnet, and K. E. Richards. 2002. Identification, subcellular localization and some properties of a cysteine-rich suppressor of gene silencing encoded by Peanut clump virus. Plant J. 29:555-567.

Harrison, B. D. 1968. Reactions of some old and new British potato cultivars to Tobacco rattle virus. Eur. Potato J. 11:165-176.

Harrison, B. D. 2002. Virus variation in relation to resistance-breaking in plants. Euphytica 124:181-192.

Harrison, B. D., and J. I. Cooper. 1974. Studies on the nature of the resistance of potato cultivars to Tobacco rattle virus. Potato Res. 17:348-349.

Hull, R. 2002. Matthew's Plant Virology. $4^{\text {th }}$ ed. Academic Press, San Diego, CA.

Kang, B.-C., I. Yeam, and M. M. Jahn. 2005. Genetics of plant virus resistance. Annu. Rev. Phytopathol. 43: 581-621.

Kavanagh, T., M. Goulden, S. S. Cruz, S. Chapman, I. Barker, D. Baulcombe.1992. Molecular analysis of a resistance-breaking strain of Potato virus X. Virology 189:609617.

Köhm, B. A., M. G. Goulden, J. E. Gilbert, T. A. Kavanagh, and D. C. Baulcombe. 1993. A Potato virus $X$ resistance gene mediates an induced, nonspecific resistance in protoplasts. Plant Cell 5:913-920.

Koonin, E. V., V. P. Boyko, and V. V. Dolja. 1991. Small cysteine-rich proteins of different groups of plant RNA viruses are related to different families of nucleic acid-binding proteins. Virology 181:395-398.

Li, H.- W., A. P. Lucy, H. -S. Guo, W. -X. Li, L. -H. Ji, S. -M. Wong, and S. -W. Ding. 1999. Strong host resistance targeted against a viral suppressor of the plant gene silencing defense mechanism. EMBO J.18:2683-2691.

Liu, H., B. Reavy, M. Swanson, and S. A. MacFarlane. 2002. Functional replacement of the Tobacco rattle virus cysteine-rich protein by pathogenicity proteins from unrelated plant viruses. Virology 298:232-239. 
Mérai, Z., Z. Kerényi, S. Kertész, M. Magna, L. Lakatos, and D. Silhavy. 2006. Doublestranded RNA binding may be a general plant RNA viral strategy to suppress RNA silencing. J. Virol. 80:5747-5756.

Mojtahedi, H., J. M. Crosslin, G. S. Santo, C. R. Brown, and P. E. Thomas. 2001. Pathogenicity of Washington and Oregon isolates of Tobacco rattle virus on potato. Am. J. Potato Res. 78:183-190.

Reavy, B., S. Dawson, T. Canto, and S. A. MacFarlane. 2004. Heterologous expression of plant virus genes that suppress post-transcriptional gene silencing results in suppression in RNA interference in Drosophila cells. BMC Biotechnol. 4:18.

Ritter, E., T. Debener, A. Barone, F. Salamini, and C. Gebhardt. 1991. RFLP mapping on potato chromosomes of two genes controlling extreme resistance to Potato virus $X$ (PVX). Mol. Gen. Genet. 227:81-85.

Robinson, D. J. 2004. Identification and nucleotide sequence of a Tobacco rattle virus RNA1 variant that causes spraing disease in potato cv. Bintje. J. Phytopathol. 152:286-290.

Savenkov, E. I., A. G. Solovyev, and S. Yu. Morozov. 1998. Genome sequences of Poa semilatent and Lychnis ringspot Hordeiviruses. Arch. Virol. 143:1379-1393.

Solomon-Blackburn, R. M., and H. Barker. 2001. A review of host major-gene resistance to Potato viruses $X, Y, A$, and $V$ in potato: genes, genetics and mapped locations. Heredity 86:8-16.

Soosaar, J. L. M., T. M. Bursh-Smith, and S. P. Dinesh-Kumar. 2005. Mechanisms of plant resistance to viruses. Nature Rev. 3:789-798.

Te, J., U. Melcher, A. Howard, and J. Verchot-Lubicz. 2005. Soilborne wheat mosaic virus (SBWMV) 19K protein belongs to a class of cysteine-rich proteins that suppress RNA silencing. Virology J. 2:18.

Valkonen, J. P. T. 1997. Novel resistances to four potyviruses in tuber-bearing potato species, and temperature-sensitive expression of hypersensitive resistance to Potato virus Y. Ann. Appl. Biol. 130:91-104.

Valkonen, J. P. T., R. A. C. Jones, S. A. Slack, and K. N. Watanabe. 1996. Resistance specificities to viruses in potato: Standardisation of nomenclature. Pl. Breeding 115:433438. 
Varrelmann, M., E. Maiss, R. Pilot, and L. Palkovics. 2007. Use of pentapeptide insertion scanning mutagenesis for functional mapping of Plum pox virus helper component proteinase suppressor of gene silencing. J. Gen. Virol 88:1005-1015.

Voinnet, O. 2005. Induction and suppression of RNA silencing: insights from viral infections. Nature Rev. Genet. 6:206-220.

Voinnet, O., Y. M. Pinto, and D. C. Baulcombe. 1999. Suppression of gene silencing: A general strategy used by diverse DNA and RNA viruses of plants. Proc. Natl. Acad. Sci. USA 96:14147-14152.

Yelina, N. E., E. I. Savenkov, A. G. Solovyev, S. Y. Morozov, and J. P. T. Valkonen. 2002. Long-distance movement, virulence, and RNA silencing suppression controlled by a single protein in Hordei- and Potyviruses: complementary functions between virus families. J. Virol. 76:12981-12991. 


\section{SUMMARY}

Tobacco rattle virus (TRV), which belongs to the genus "Tobravirus", possesses a bipartite positive-single-stranded genome (RNA-1 and -2), and is naturally transmitted by the plant ectoparasites trichdorids nematodes. The virus is infecting the cultivated potato (Solanum tuberosum ssp. tuberosum) and causing spraing symptoms in progeny tubers. These symptoms severely affect tuber quality and destroy the crop's sale potential for human consumption and industrial use. Spraing can be induced only when the virus is transmitted by its natural vector. Therefore, screening for resistance to spraing in potato is based only on exposure to nematode infection in naturally infested soils, which is time-consuming and often yields in varying results due to the inconsistent conditions. Since the basis of resistance to TRV in the potato plant is unknown, and a promising biotest for breeding is still missing, we developed a reliable and fast resistance test to screen for TRV resistance in different potato cultivars by leaf-inoculation with a full-length RNA-1 cDNA clone and RNA-2 cDNA clone expressing the fluorescent marker protein DsRed of TRV isolate PpK20. This DsRed expressing TRV cDNA clone (TRV-DsRed) enabled us to detect the virus replication in initially inoculated cells and to monitor its movement to non-inoculated tissues. Additionally examining three potato cultivars with well-known reaction to natural nematode infection with TRV-PpK20 has given the opportunity to compare host resistance responses upon leafinoculation with resistance to spraing. As a result, several different resistance responses of potato cultivars have been characterized, and the viral avirulence gene (avr) eliciting the resistance has been determined.

Mechanical inoculations of potato cultivars analyzed with TRV-DsRed, followed by confocal laser scanning microscopy (CLSM) analysis of RNA-2-expressed DsRed fluorescent and RT-PCR detection of both RNAs, revealed three different host reactions fit nicely into the classical categories of incompatible host resistance response in potato to virus infection: i) a spreading necrosis in inoculated leaves of cv. 'Russet Burbank' followed with virus spreading to non-inoculated leaves; ii) a 'hypersensitive-like resistance' (HR-like) in the spraing resistant cv. 'Bintje' characterized by the replication of the virus in the initially infected leaf cells before the necrotic lesions were formed, where the virus then was unable to move outside the necrotic area; iii) an 'extreme resistance' (ER) functions at the single cell level characterized by the rapid arrest of virus replication with no visible reacton developed in inoculated leaves. This suggests that spraing and resistance to spraing are not determined 
by factors of the virus vector. In comparison with PpK20, mechanical inoculation with the TRV resistance-breaking isolate $\mathrm{PpO} 85 \mathrm{M}$, known to overcome spraing resistance in cv. 'Bintje', revealed identical reactions in inoculated leaves of cvs. 'Russet Burbank' and 'Bintje'. In contrast, PpO85M induced HR-like in inoculated leaves of cv. 'Saturna'. The virus was able to accumulate in the inoculated leaves of the three cultivars, but unable to establish a systemic infection. This is the first report of a resistance response in the potato plant displaying isolate-specific ER and HR-like respectively. Constitutive expression of both viral RNAs (TRV-DsRed) using Agrobacterium-mediated transient expression (leafinfiltration) assay showed identical host reactions in cvs. 'Russet Burbank' and 'Bintje' plants, whereas 'Saturna' plants displayed necrosis and cell death, concluding that by parallel infection of a multitude of leaf cells, an HR-like was expressed in the ER plants. Altogether, obtained results suggested a monogenic dominant inheritance mediated by one single or two different resistance genes, and therefore one viral gene might represent the elicitor of these two newly identified resistance responses to mechanical TRV-PpK20 inoculation in 'Bintje' and 'Saturna'.

Agrobacteruim-transient expression of the 29K open reading frame (ORF) encoded by TRV-RNA-1-PpK20, either from a binary vector or from Potato virus X (PVX) expression vector, demonstrated that the $29 \mathrm{~K}$ is the elicitor of resistance in both the HR-like and ER potato cultivars, and that this eliciting function is independent of any other encoded genes or virus replication. Agroexpression of 29k-PpO85M did not induce HR in cv. 'Bintje'; but unexpectedly, it induced HR-like in cv. 'Saturna', concluding that the resistance between both cultivars is different. Sequence comparison at the amino acid level of $29 \mathrm{~K}$ encoded by different TRV isolates, supported by phylogenetic tree showed that $29 \mathrm{~K}$ from PpO85M isolate displayed the highest sequence divergence compared to those from other TRV isolates (95-98\%), with the exsistence of 10 amino acid positions differences between $29 \mathrm{~K}-\mathrm{PpK} 20$ and $-\mathrm{PpO} 85 \mathrm{M}$.

TRV 16K cystein-rich protein (CRP) possesses a pathogenicity factor and a suppressor of RNA silencing function. This CRP has limited homology sequence with any of the other CRPs encoded by plant viruses. Since the silencing suppression activity of $16 \mathrm{~K}$ has not been investigated in planta, and the reports on the subcellular localization of this protein are conflicting, we aimed to characterize the silencing suppression activity of TRV-16KPpK20 in GFP-transgenic Nicotiana benthamiana plants, and to investigate its participation in the virus life cycle and subcellular localization. Using an Agrobacterium-mediated 
transient assay, we demonstrated for the first time the silencing suppression activity of $16 \mathrm{~K}$ in planta. The protein efficiently prevented the GFP-mRNA degradation, and slightly reduced the accumulation of specific short interfering RNAs (siRNA) of GFP suggested that the protein exerts its activity on a step downstream of siRNA production and therefore might interfere with the initiation step of RNA silencing. Analysis of transiently expressed 30 independent $16 \mathrm{~K}$ mutants, resulting from the pentapeptide insertion scanning mutagenesis (PSM), revealed that two regions tolerated the 5 aa insertions. These two regions coincide with sequence variability between tobravirus CRPs, suggesting a strong functional and possibly structural conservation of TRV $16 \mathrm{~K}$.

CLSM analysis of $N$. benthamiana epidermal cells agroinfiltrated with 35S-driven DsRed C-terminal fusions of a set of peptides demonstrated that $16 \mathrm{~K}$ possesses two independent bipartite nuclear localization signals (NLSs) in the C-terminal half of the protein, indicating a nuclear role of $16 \mathrm{~K}$. The full-length $16 \mathrm{~K}$, in addition to cytoplasmic localization, was able to traffic into the nucleus and nucleolus. In contrast, the N-terminal half was localized mainly in the cytoplasm and excluded from the nucleus, suggesting the presence of a nuclear export or a cytoplasmic retention signal.

Sequence comparison of $16 \mathrm{~K}$ was much more extensive with $12 \mathrm{~K}$ CRPs from the two closely related tobaravirus members (PEBV and PepRSV) than other suppressor of silencing CRPs from different RNA viruses, suggesting that $16 \mathrm{~K}$ and $12 \mathrm{~K}$ have a functional homology. The sequence showed also a 35 amino acid gap in both $12 \mathrm{~K}$ proteins in comparison with $16 \mathrm{~K}$, which affects both NLSs identified in $16 \mathrm{~K}$. However, the sequence variability between $16 \mathrm{~K}$ and both $12 \mathrm{~K}$ proteins nicely correlates with the tolerance of $16 \mathrm{~K}$ silencing suppression to pentapeptide insertions, which may present good evidence that these two parts of $16 \mathrm{~K}$ are not necessary for silencing suppression function.

In conclusion, our results revealed that agroexpression of the elicitor of the resistance is an excellent tool to screen crossing populations, as it gives much faster and more reliable information about the susceptibility of breeding lines against TRV infection than the resistance assessment in the field in natural infested soils. The characterization of different host resistance responses to TRV in potato will help in understanding the mode of inheritance of TRV resistance, as well as in identifying molecular markers to facilitate the selection process for TRV resistance by mapping and identification of the TRV resistance gene(s). The silencing suppression activity of $16 \mathrm{~K}$ is somehow organism specific, depending on the assay 
applied. The proposed mode of action for $16 \mathrm{~K}$, possibily interfere with an initiation and/or maintenece steps of the RNA silencing machinery and it's speculated nuclear role make this protein a unique suppressor among other known plant viral suppressor CRPs. 


\section{ACKNOWLEDGMENTS}

I would like to express my sincere grateful and deep appreciation to Prof. Dr. Mark Varrelmann, Departemnt of Crops Sciences, Section Plant virology, Faculty of Agriculture, Georg-August University Göttingen, for his supervision, guidance, constructive criticism and the unfailing help during the whole course of this study.

My sincere grateful and thanks also go to my co-refree Prof. Dr. Edgar Maiss, University of Hannover, for his valuable comments on the dissertation.

Special thanks go also to Dr. Stephan Winter, DSMZ, for the production and purification of the TRV $16 \mathrm{~K}$ antiserum.

I am thankful also to Angelika Waltermann, University of Hannover, for her help in the CLSM analysis.

Special thanks go as well to Ruth Pilot for her great technical assistance, particularly, in the northernblotting analysis.

I also feel most indebted and grateful to all the staff members and colleagues in the virology lab, for their encouragement and considerable help that made this work possible.

I am most grateful to $\boldsymbol{m y}$ wife "Maisoun" for her moral support, understanding and consideration during the course of my study.

Finally, I am greatly indebted to the Islamic Development Bank (IDB), Scholarship Merit program, for finiacial support of this work. 


\section{CURRICULUM VITAE}

Name

Date of Birth

Place of Birth

Gender

\section{Education}

1974-1982

1982-1986

1986-1992

1993-1998

2003-2007

\section{Professional Experience}

1992-1993

1994-1998

1999-2003
Walid Ghazala

05.08 .1968

Kuwait

Male

Elementary and Junior School $\left(1-8^{\text {th }}\right.$ grade), Kuwait

High Secondary School (9-12 ${ }^{\text {th }}$ grade), Kuwait

B.Sc. Degree in Plant Protection, Damascus

University, Damascus, Syria

M.Sc. Degree in Plant Pathology, Ain-Shams

University, Cairo, Egypt

Ph.D. Degree at the Georg-August University

Göttingen, Faculty of Agriculture, Department of Crop Sciences, Section Plant Virology.

Working with the scientific team of controlling the most important diseases and insects infecting Apples, Grapes and Olives in Syria, Ministry of Agriculture and Agrarian Reform (MAAR), Damascus, Syria.

A membership in the Egyptian Scientific Team of Seed-Transmitted Virus Diseases Project incorporating with The Danish Government Institute for Seed Pathology (DGISP).

A researcher at the Department of Virus Diseases, Plant Pathology Division, Administration of Plant Protection Researches (APPR), General Commission of Scientific Agricultural Research (GCSAR), Damascus, Syria 